\title{
Information Handbook on Independent Spent Fuel Storage Installations
}

Manuscript Completed: December 1996

Date Published: December 1995

M. G. Raddatz, M. D. Waters

Spent Fuel Project Office

Office of Nuclear Material Safety and Safeguards

U.S. Nuclear Regulatory Commission

Washington, DC 20555-0001

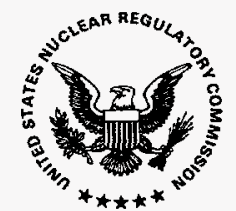




\section{DISCLAMMER}

Portions of this document may be illegible in electronic image products. Images are produced from the best available original document. 


\section{DISCLAIMER}

This report was prepared as an account of work sponsored by an agency of the United States Government. Neither the United States Government nor any agency thereof, nor any of their employees, makes any warranty, express or implied, or assumes any legal liability or responsibility for the accuracy, completeness, or usefulness of any information, apparatus, product, or process disclosed, or represents that its use would not infringe privately owned rights. Reference herein to any specific commercial product, process, or service by trade name, trademark, manufacturer, or otherwise does not necessarily constitute or imply its endorsement, recommendation, or favoring by the United States Government or any agency thereof. The views and opinions of authors expressed herein do not necessarily state or reflect those of the United States Government or any agency thereof. 

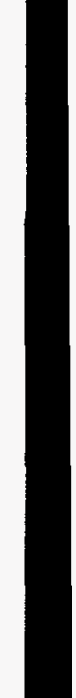

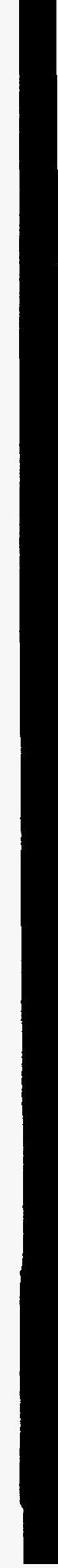




\begin{abstract}
In this information handbook, the staff of the U.S. Nuclear Regulatory Commission describes (1) background information regarding the licensing and history of independent spent fuel storage installations (ISFSIs), (2) a discussion of the licensing process, (3) a description of all currently approved or certified models of dry cask storage systems (DCSSs), and (4) a description of sites currently storing spent fuel in an ISFSI. Storage of spent fuel at ISFSIs must be in accordance with the provisions of 10 CFR Part 72.

The staff has provided this handbook for information purposes only. The accuracy of any information herein is not guaranteed. For verification or for more details, the reader should refer to the respective docket files for each DCSS and ISFSI site. The information in this handbook is current as of September 1, 1996.

Comments, which would make future revisions of this handbook more useful, are invited and should be directed to:

Mr. Michael D. Waters

Spent Fuel Project Office

Office of Nuclear Material Safety and Safeguards

U.S. Nuclear Regulatory Commission

Washington, D.C. 20555-0001
\end{abstract}





\section{CONTENTS}

Page

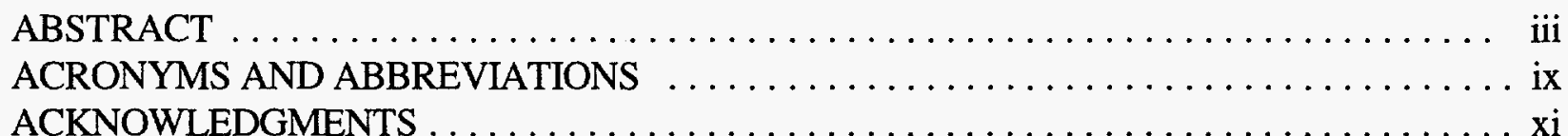

1 INTRODUCTION $\ldots \ldots \ldots \ldots \ldots \ldots \ldots \ldots \ldots \ldots \ldots \ldots \ldots \ldots \ldots \ldots \ldots \ldots \ldots$

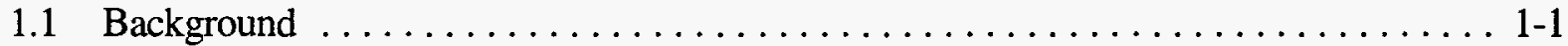

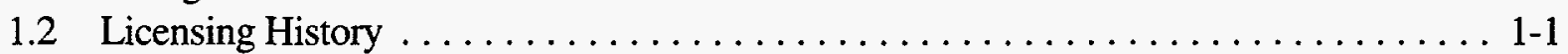

1.3 Overview of Current ISFSIs (September 1996) $\ldots \ldots \ldots \ldots \ldots \ldots \ldots \ldots \ldots \ldots$

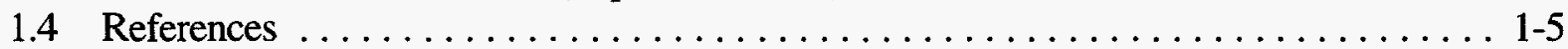

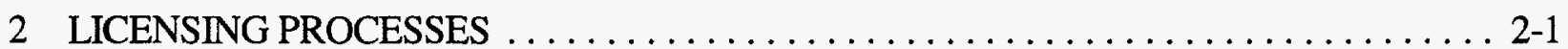

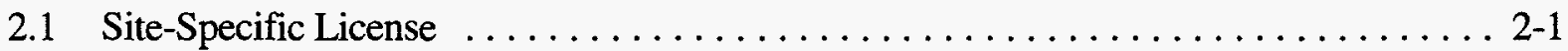

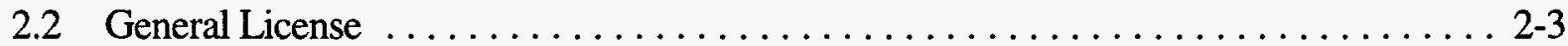

2.3 License Advantages and Disadvantages $\ldots \ldots \ldots \ldots \ldots \ldots \ldots \ldots \ldots \ldots \ldots \ldots$

2.4 Applicable Regulatory Guides and Additional Guidance $\ldots \ldots \ldots \ldots \ldots \ldots \ldots$

3 APPROVED DRY CASK STORAGE SYSTEMS $\ldots \ldots \ldots \ldots \ldots \ldots \ldots \ldots \ldots \ldots \ldots$

3.1 Castor V/21: Certificate of Compliance $\# 1000 \ldots \ldots \ldots \ldots \ldots \ldots \ldots \ldots \ldots$

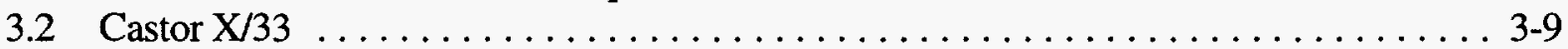

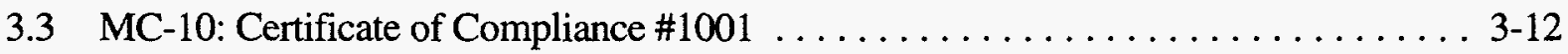

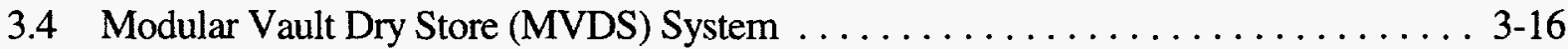

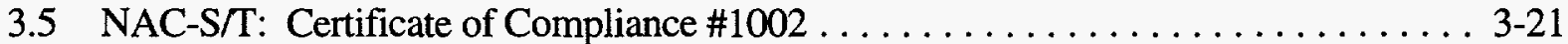

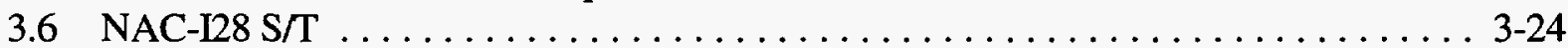

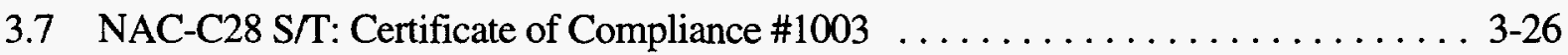

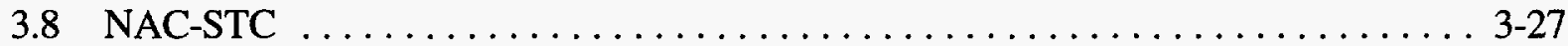

3.9 NUHOMS-7P . . . . . . . . . . . . . . . . . . . . . . . . . . . 3-29

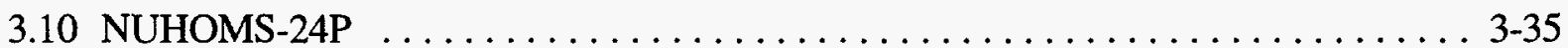

3.11 Standardized NUHOMS-24P/52B: Certificate of Compliance \#1004 . . . . . . . . 3-42

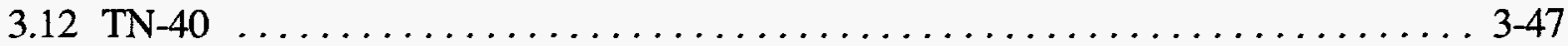

3.13 TN-24: Certificate of Compliance \#1005 . . . . . . . . . . . . . . . . 3-51

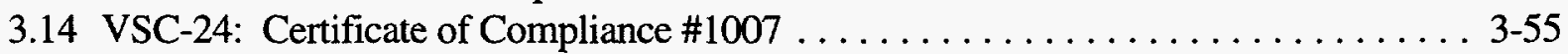

4 SITE-SPECIFIC ISFSIs $\ldots \ldots \ldots \ldots \ldots \ldots \ldots \ldots \ldots \ldots \ldots \ldots \ldots \ldots \ldots \ldots \ldots \ldots \ldots \ldots .1$

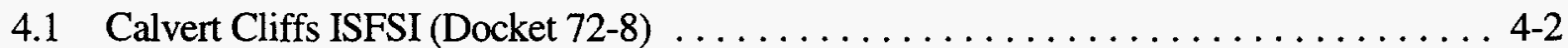

4.2 Fort St. Vrain ISFSI (Docket $72-9) \ldots \ldots \ldots \ldots \ldots \ldots \ldots \ldots \ldots \ldots \ldots \ldots \ldots$

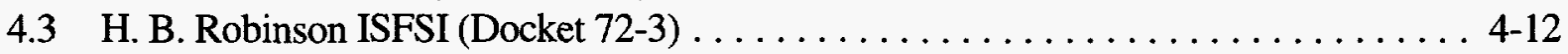

4.4 Oconee ISFSI (Docket 72-4) . . . . . . . . . . . . . . . . . . . . . . 4-16

4.5 Prairie Island ISFSI (Docket $72-10) \ldots \ldots \ldots \ldots \ldots \ldots \ldots \ldots \ldots \ldots . \ldots \ldots$

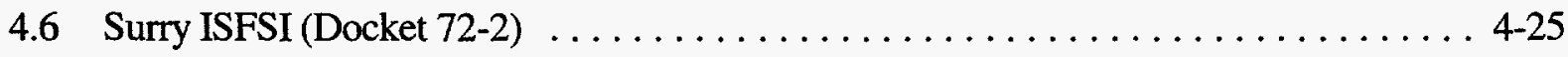




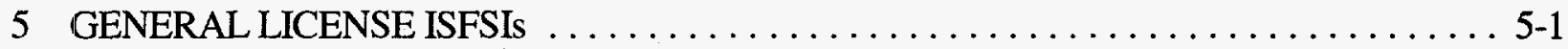

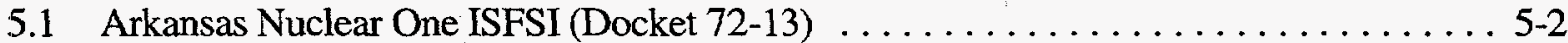

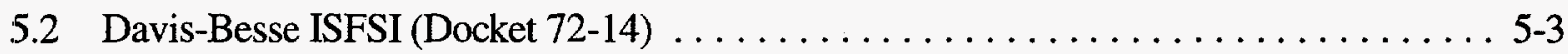

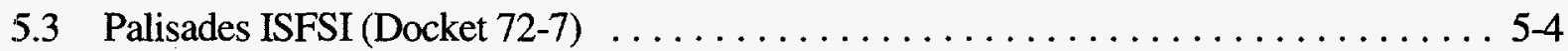

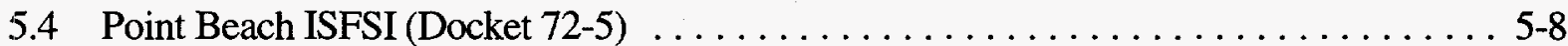

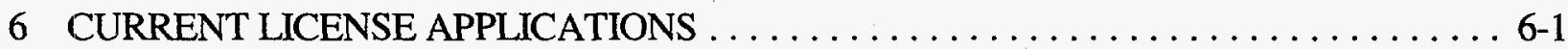

7 MRS/MPC AND PRIVATE AWAY-FROM-REACTOR INITIATIVES (for later use) . . . 7-1

\section{FIGURES}

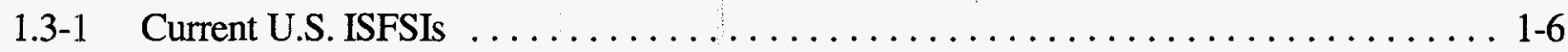

$1.3-2$ Potential ISFSIs Needed in Near Future $\ldots \ldots \ldots \ldots \ldots \ldots \ldots \ldots \ldots \ldots \ldots \ldots .1-7$

1.3-3 Time-Line of DCSS and ISFSI Licensing/Operating Dates $\ldots \ldots \ldots \ldots \ldots \ldots \ldots \ldots$

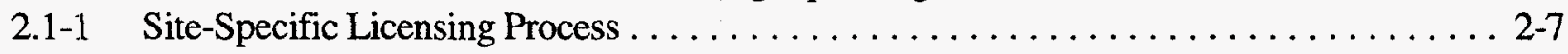

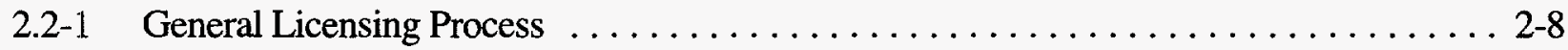

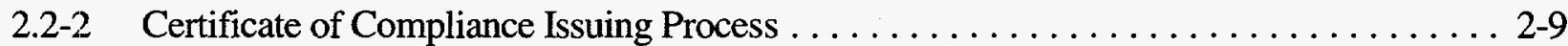

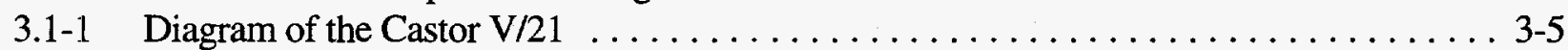

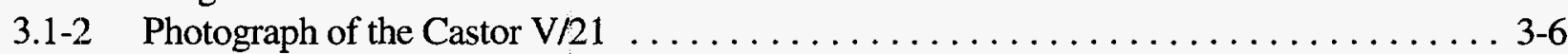

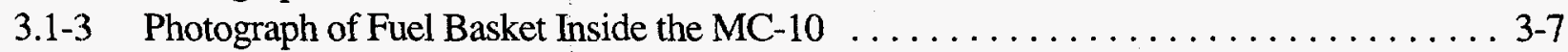

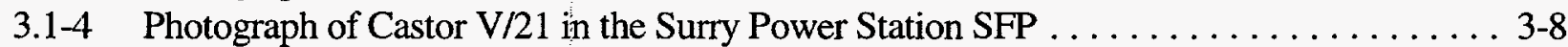

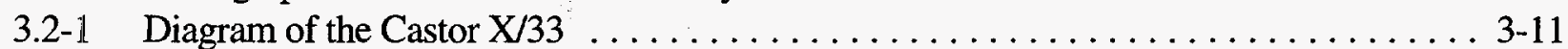

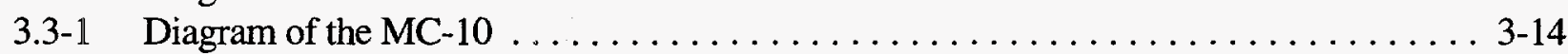

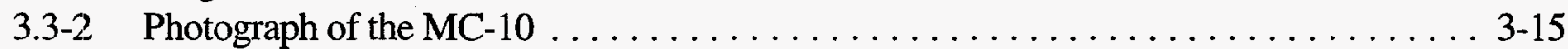

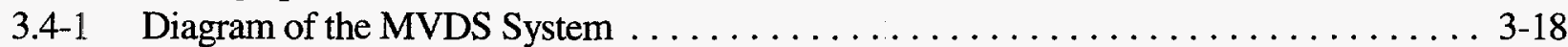

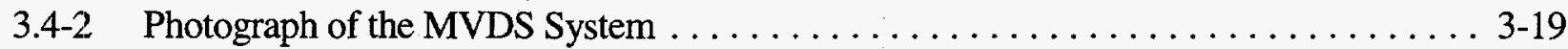

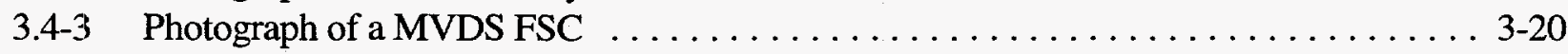

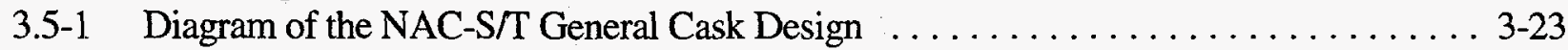

3.9-1 Diagram of the NUHOMS-7P DSC . . . . . . . . . . . . . . . . . . $3-31$

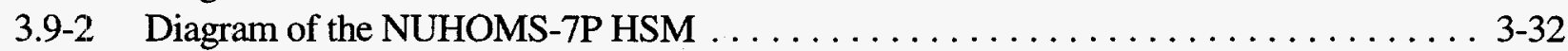

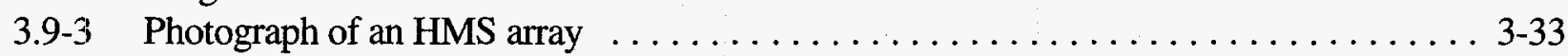

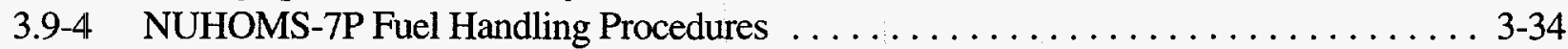

3.10-1 Diagram of the NUHOMS-24P DSC . . . . . . . . . . . . . . . . . . . 3-38

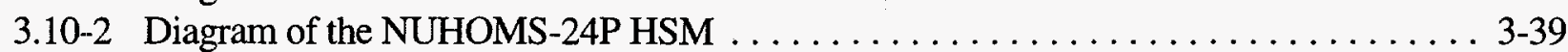

3.10-3 Diagram of a NUHOMS On-Site Transfer Cask . . . . . . . . . . . . . . $3-40$

3.10-4 Photograph of a NUHOMS TC Being Mated with an HSM . . . . . . . . . . 3 3-41

3.11-1 Diagram of the Standardized NUHOMS DSC $\ldots \ldots \ldots \ldots \ldots \ldots \ldots \ldots \ldots .4 .45$

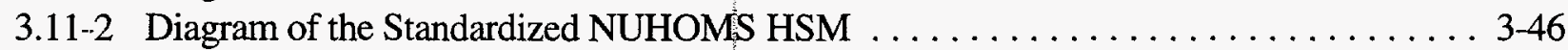

$3.12-1$ Diagram of the TN-40 . . . . . . . . . . . . . . . . . . . . . . . 3-49

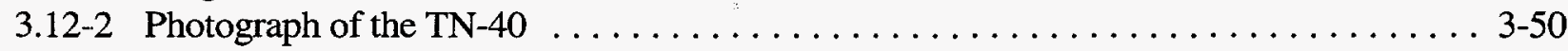


3.13-1 Diagram of the TN-24 ... . . . . . . . . . . . . . . . . . . $3-53$

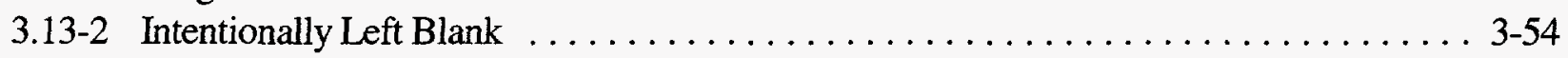

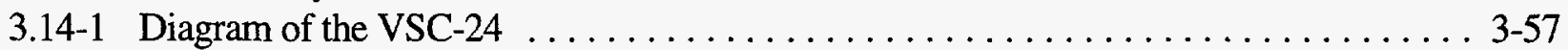

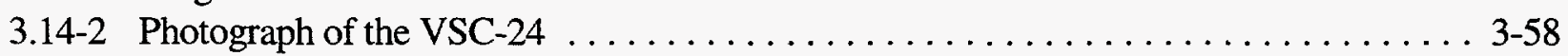

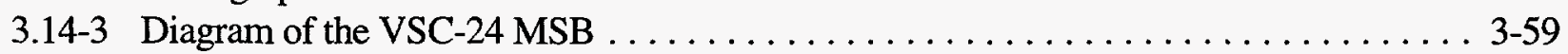

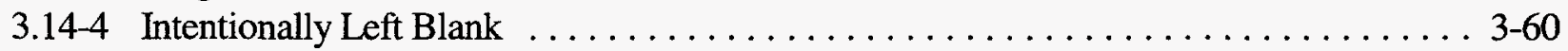

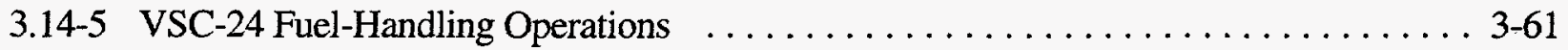

4.1-1 Calvert Cliffs Nuclear Power Plant Area Map . . . . . . . . . . . . . . . . . 4-3

4.1-2 Calvert Cliffs Nuclear Power Plant Site Map $\ldots \ldots \ldots \ldots \ldots \ldots \ldots \ldots \ldots \ldots .4$

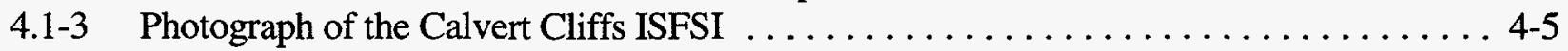

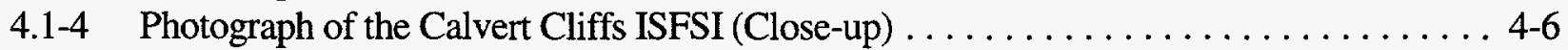

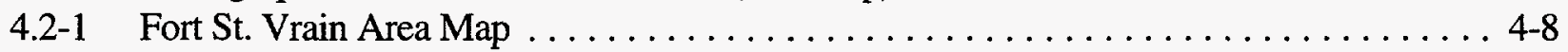

$4.2-2$ Fort St. Vrain Site Map . . . . . . . . . . . . . . . . . . . . . . 4-9

$4.2-3$ Photograph of the Fort St. Vrain ISFSI $\ldots \ldots \ldots \ldots \ldots \ldots \ldots \ldots \ldots \ldots \ldots \ldots \ldots$

4.2-4 Photograph of the Fort St. Vrain ISFSI (Close-up) . . . . . . . . . . . . . . 4-11

4.3-1 H.B. Robinson Unit 2 Area Map . . . . . . . . . . . . . . . . . . . 4-13

4.3-2 H.B. Robinson Unit 2 Site Map . . . . . . . . . . . . . . . . . . . . . 4-14

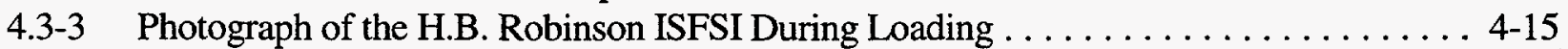

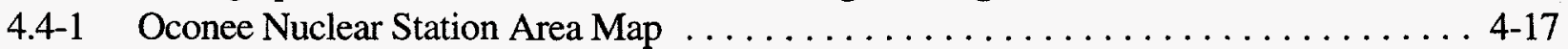

4.4-2 Oconee Nuclear Station Site Map . . . . . . . . . . . . . . . . . . 4-18

4.5-1 Prairie Island Nuclear Generating Station Area Map . . . . . . . . . . . . . . . 4-21

4.5-2 Prairie Island Nuclear Generating Station Site Map . . . . . . . . . . . . . . . . . 4-22

4.5-3 Photograph of the Prairie Island ISFSI $\ldots \ldots \ldots \ldots \ldots \ldots \ldots \ldots \ldots \ldots \ldots \ldots . \ldots \ldots$

4.5-4 Photograph of the Prairie Island ISFSI (Close-up) . . . . . . . . . . . . . . . . 4-24

4.6-1 Surry Power Station Area Map . . . . . . . . . . . . . . . . . . . . . . 4-27

$4.6-2$ Surry Power Station Site Map . . . . . . . . . . . . . . . . . . . . . 4-28

4.6-3 Photograph of the Surry ISFSI . . . . . . . . . . . . . . . . . . . . . . . . . . . 4-29

4.6-4 Photograph of the Surry ISFSI (Close-up) . . . . . . . . . . . . . . . . . . 4-30

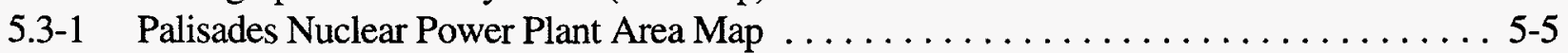

5.3-2 Palisades Nuclear Power Plant Site Map . . . . . . . . . . . . . . . . . . . 5-6

5.3-3 Photograph of the Palisades ISFSI . . . . . . . . . . . . . . . .

\section{TABLES}

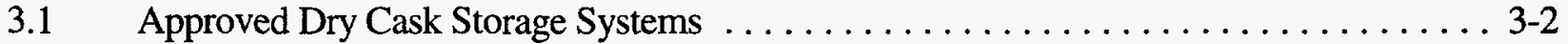

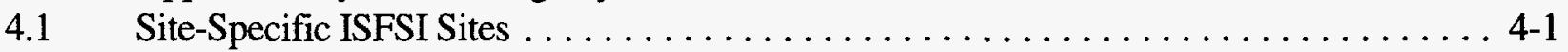

$5.1 \quad$ General License ISFSIs $\ldots \ldots \ldots \ldots \ldots \ldots \ldots \ldots \ldots \ldots \ldots \ldots \ldots \ldots \ldots \ldots \ldots \ldots$

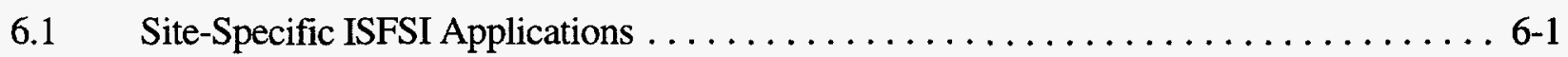

$6.2 \quad$ DCSS Applications $\ldots \ldots \ldots \ldots \ldots \ldots \ldots \ldots \ldots \ldots \ldots \ldots \ldots \ldots \ldots \ldots$

APPENDIX A Glossary 



\section{ACRONYMS AND ABBREVIATIONS}

$\begin{array}{ll}\text { ANS } & \text { American Nuclear Society } \\ \text { ANSI } & \text { American National Standards Institute } \\ \text { ASME } & \text { American Society of Mechanical Engineers } \\ \text { BG\&E } & \text { Baltimore Gas \& Electric Company } \\ \text { CFR } & \text { Code of Federal Regulations } \\ \text { CFS } & \text { charge face structures } \\ \text { CHM } & \text { container handling machine } \\ \text { COC } & \text { certificate of compliance } \\ \text { CPC } & \text { Consumers Power Company of Michigan } \\ \text { CP\&L } & \text { Carolina Power \& Light Company } \\ \text { DOE } & \text { Department of Energy } \\ \text { DSC } & \text { dry shielded canister } \\ \text { DCSS } & \text { dry cask storage system } \\ \text { EA } & \text { environmental assessment } \\ \text { EIS } & \text { environmental impact statement } \\ \text { EP } & \text { emergency plan } \\ \text { EPRI } & \text { Electric Power Research Institute } \\ \text { ER } & \text { environmental report } \\ \text { FONSI } & \text { finding of no significant impact } \\ \text { FR } & \text { Federal Register } \\ \text { FSC } & \text { fuel storage container } \\ \text { GEIS } & \text { Generic Environmental Impact Statement } \\ \text { HRM } & \text { hydraulic ram system } \\ \text { HSM } & \text { horizontal storage module } \\ \text { HTGC } & \text { high-temperature, gas-cooled reactor } \\ \text { INEL } & \text { Idaho National Engineering Laboratory } \\ \text { ISFSI } & \text { independent spent fuel storage installation } \\ \text { LWR } & \text { light-water reactor } \\ \text { MPC } & \text { multi-purpose canister } \\ \text { MPUC } & \text { Minnesota Public Utilities Commission } \\ \text { MRS } & \text { monitored retrievable storage installation } \\ \text { MSB } & \text { multi-assembly sealed basket } \\ \text { MTC } & \text { multi-assembly sealed basket transfer cask } \\ \text { MTU } & \text { metric tons of uranium } \\ \text { MVDS } & \text { modular vault dry store } \\ \text { NAC } & \text { Nuclear Assurance Corporation } \\ \text { NEPA } & \text { National Environmental Policy Act of 1969, as amended } \\ \text { NMSS } & \text { Nuclear Material Safety and Safeguards } \\ \text { NRC } & \text { Nuclear Regulatory Commission } \\ & \end{array}$


NSP Northern States Power Company

NWPA Nuclear Waste Policy Act of 1982, as amended

PSC Public Service Company of Colorado

PWR pressurized water reactor

ROD record of decision

SAR safety analysis report

SER safety evaluation report

SFA spent fuel assembly

SFP spent fuel pool

SNM special nuclear materials license

TAN Test Area North

TC transfer cask

TMI-2 Three Mile Island Unit 2

VCC ventilated concrete cask

VM vault module

VEFCO Virginia Electric \& Power Company

VSC ventilated storage cask

WCD Waste Confidence Decision

WEPCO Wisconsin Electric Power Company

WNP2 Washington Public Power System 


\section{ACKNOWLEDGMENTS}

The Authors would like to acknowledge the contributions of David H. Williamson, a Senior Engineer with SAIC, in the publication of this document. His efforts in the organization of the tremendous amount of information on spent fuel licensing, into a concise format were invaluable. Thanks also to the project managers within the Spent Fuel Licensing Section for their exceptional knowledge and advise. And special thoughts to Mr. Jim Taylor, Mr. Bill Russell, and Mr. Robert Bernero, all of whom originally requested this handbook. 


\section{INTRODUCTION}

An independent spent fuel storage installation (ISFSI) is a complex designed and constructed for the interim storage of spent nuclear fuel and other radioactive materials associated with spent fuel storage. It is a solution for extending the storage capacity for spent fuel at a reactor site that lacks sufficient spent fuel pool (SFP) storage capacity. All licensed ISFSI designs utilize dry cask storage systems (DCSSs) that provide confinement, radiological shielding, physical protection, and inherently passive cooling of its spent nuclear fuel during normal, off-normal, and accident conditions. A typical ISFSI consists of several DCSSs arranged on a reinforced-concrete pad in a secured area within the physical boundary of a nuclear power plant.

In this handbook, the staff presents (1) background information regarding the licensing and history of ISFSIs, (2) a discussion of the licensing process, (3) a description of all currently approved or certified DCSSs, and (4) a description of sites currently storing spent fuel in an ISFSI.

\subsection{Background}

Most U.S. nuclear power plant SFPs were not originally designed to have a storage capacity for all the spent fuel generated by their reactors. Utilities originally planned for spent fuel to remain in the SFP for a few years after discharge, and then to be sent to a reprocessing facility. However, the U.S. Government declared a moratorium on reprocessing in 1977. Although the ban was later lifted, reprocessing was eliminated as a feasible option. Consequently, utilities expanded the storage capacity of their SFPs by using high-density storage racks. This has been only a short-term solution and many utilities have reached, or will soon reach, their SFP storage capacity.

Utilities now plan to eventually ship their spent fuel to a geologic repository operated by the U.S. Government. The Nuclear Waste Policy Act of 1982, as amended (NWPA) requires the U.S. Department of Energy (DOE) to begin accepting spent fuel for permanent disposal by 1998 . However, the federal repository still remains in the planning stages, and will not be able to accept spent fuel by 1998. A new date (approximately 2010) has been proposed as the year when the repository will be opened. Because there is no other federal disposal option, U.S. utilities have developed ISFSIs as a means for expanding their spent fuel storage capacity on an interim basis.

\subsection{Licensing History}

The sections that follow discuss major milestones regarding the licensing history of ISFSIs.

\subsubsection{Issuance of 10 CFR Part 72}

ISFSI regulation was originally governed by 10 CFR Part 70, "Domestic Licensing of Special Nuclear Material." In 1974, the Atomic Energy Commission (predecessor of the NRC) issued a regulatory guide on storage of spent fuel in ISFSIs, Regulatory Guide 3.24, "Guidance on the License Application, Siting, Design, and Plant Protection for an Independent Spent Fuel Storage Installation," 
which then supported 10 CFR Part 70. The need for regulation to specifically address spent fuel storage was supported by the "Final Generic Environmental Impact Statement [GEIS] on Handling and Storage of Spent Light Water Power Reactor Fuel" (Ref. 1). In GEIS, the staff predicted that additional storage capacity outside reactor storage basins would be needed, conservatively assuming that neither reprocessing facilities nor a geologic repository would be available before the year 2000 . In November 1980, the staff issued 10 CFR Part 72, "Licensing Requirements for the Storage of Spent Fuel in an Independent Spent Fuel Storage Installation," superseding 10 CFR Part 70 and Regulatory Guide 3.24 with respect to the regulation of spent fuel storage in ISFSIs.

The staff developed 10 CFR Part 72 specifically for spent fuel storage outside reactor storage basins. The regulation covers both wet and dry storage systems for site-specific ISFSIs that can be located either at reactor sites or away from them. Therefore, an ISFSI license is a materials license and not a facility license. It requires one-step licensing, in which it is not necessary to first obtain a construction permit and then an operating license, as is required for a facility license. The Part 72 license is, in a sense, a renewal of authorization to receive and store spent fuel, which had previously been granted under the general regulations 10 CFR Parts 30 and 40, and in particular 10 CFR Part 70, "Domestic Licensing of Special Nuclear Material." The renewal license period under 10 CFR Part 72 is 20 years.

In 1986, the Surry Nuclear Power Plant (see Section 4.6) became the first utility in the U.S. to obtain a license to store spent nuclear fuel in a site-specific ISFSI under the requirements of 10 CFR Part 72. DCSS designs were developed in conjunction with DOE by the passage of the NWPA as described in the next section.

\subsubsection{Nuclear Waste Policy Act of $\mathbf{1 9 8 2}$}

The Nuclear Waste Policy Act of 1982, as amended (NWPA) gave directed the DOE to work with utilities and develop DCSS technologies to safely store spent fuel in a dry mode (Ref. 2). Section 218(a) of the NWPA includes the following directive: "The Secretary [of DOE] shall establish a demonstration program in cooperation with the private sector, for the dry storage of spent nuclear fuel at civilian nuclear power reactor sites, with the objective of establishing one or more technologies that the [Nuclear Regulatory] Commission may, by rule, approve for use at the sites of civilian nuclear power reactors without, to the maximum extent practicable, the need for additional site specific approvals by the Commission." Some of the designs that were developed in the Demonstration Program included the Castor, MC, VSC, NUHOMS, and TN designs (see Section 3).

The NWPA also directed DOE and NRC to develop a streamlined process for licensing dry cask storage at reactor sites. Section 133 of the NWPA states, in part, that "the Commission shall, by rule, establish procedures for the licensing of any technology approved by the Commission under Section 
218(a) for use at the site of any civilian nuclear reactor." The purpose of this directive was to establish acceptable DCSS designs that preclude the need for additional site-specific reviews, because these DCSS designs would be safe and acceptable at any reactor site in the U.S. Its intent was to allow licensed reactor facilities to omit site-specific evaluations "to the maximum extent practicable."

\subsubsection{Waste Confidence Decision}

Concurrently with the directives of the NWPA, the NRC was conducting another study on DCSSs; in 1984, the NRC issued its Waste Confidence Decision (WCD), in which it reviewed dry cask storage and other spent fuel storage options (Ref. 3).

A brief summary of the findings follows:

(1) The Commission finds reasonable assurance that safe disposal of high-level radioactive waste and spent fuel in a mined geologic repository is technically feasible.

(2) The Commission finds reasonable assurance that one or more mined geologic repositories for commercial high-level radioactive waste and spent fuel will be available by the years 2007-2009, and that sufficient repository capacity will be available within 30 years beyond expiration of any reactor operating license to dispose of existing commercial high-level radioactive waste and spent fuel originating in such reactor and generated up to that time.

(3) The Commission finds reasonable assurance that high-level radioactive waste and spent fuel will be managed in a safe manner until sufficient repository capacity is available to assure the safe disposal of all high-level radioactive waste and spent fuel.

(4) The Commission finds reasonable assurance that, if necessary, spent fuel generated in any reactor can be stored safely and without significant environmental impacts for at least 30 years beyond the expiration of that reactor's operating licenses at that reactor's spent fuel storage basin, or at either onsite or offsite independent spent fuel storage installations.

(5) The Commission finds reasonable assurance that safe independent onsite or offsite spent fuel storage will be made available if such storage capacity is needed.

At the time of the WCD and the adoption of 10 CFR 51.23 "Temporary storage of spent fuel after cessation of reactor operations, generic determination of no significant environmental impact," the Commission also announced that although it believed that it could reach favorable conclusions, it also recognized that significant and unexpected events might affect its decision. Consequently, the 
Cornmission stated that it would "review its conclusions on waste confidence should significant and pertinent unexpected events occur, or at least every 5 years until a repository for high-level radioactive waste and spent fuel is available."

\subsubsection{Review of Waste Confidence Decision}

In 1989, the Commission completed a review of its earlier WCD findings. As a result of this review, the Commission modified two of its earlier findings:

(1) The Commission finds reasonable assurance that at least one mined geologic repository will be available within the first quarter of the twenty-first century, and sufficient repository capacity will be available within 30 years beyond the licensed life for operation (which may include the term of a revised or renewed license) of any reactor to dispose of the commercial high-level waste and spent fuel originating in such reactor and generated up to that time; and

(2) The Commission finds reasonable assurance that, if necessary, spent fuel generated in any reactor can be stored safely and without significant environmental impacts for at least 30 years beyond the licensed life for operation (which may include the term of a revised or renewed license) of that reactor at its spent fuel storage basin, or at either onsite or offsite ISFSIs

\subsubsection{Revision of 10 CFR Part 72 for a General License}

In July 1990, the NRC published a final rule in the Federal Register to revise 10 CFR Part 72 (Ref. 4). The revision established a new Subpart K to 10 CFR Part 72 entitled, "General License for Storage of Spent Fuel at Power Reactor Sites," and a new Subpart L to 10 CFR Part 72 entitled, "Approval of Spent Fuel Storage Casks." Subpart K gave all utilities with a 10 CFR Part 50 license a general license that allowed them to store their spent fuel in a DCSS which has received a certificate of compliance from the NRC. Subpart L describes the method for DCSS vendors to obtain a certificate of compliance, and it lists DCSS models that have certificates of compliance. The revision gave utilities the option to reduce licensing time by using an approved DCSS, as intended by the NWPA directive. The basis of the new Subparts $\mathrm{L}$ and $\mathrm{K}$ was that existing reactor sites already met most 10 CFR Part 72 licensing criteria (i.e., physical protection, environmental impact statements, emergency planning) under their 10 CFR Part 50 reactor license.

In April 1993, Palisades Nuclear Power Plant (see Section 4.5) became the first utility to use their general license provided by the revised 10 CFR Part 72. They used the VSC-24 (see Section 3.14), which has a certificate of compliance issued by the NRC. 


\subsection{Overview of Current ISFSIs (September 1996)}

Currently, there are 10 ISFSIs ( 6 site-specific and 4 general) operating in the U.S. as shown in Figure 1.3-1. These ISFSIs are discussed in Sections 4 and 5. Figure 1.3-2 shows ISFSI sites that may be licensed or operational in the near future; these are not discussed in this handbook. A time-line of DCSS and ISFSI licensing/operating dates are shown in Figure 1.3-3.

Four general DCSS design types have been approved for use in licensed ISFSIs: metal storage casks, concrete storage casks, metal canisters housed in concrete modules, and concrete storage vaults. A total of 14 DCSS models made by seven different vendors has been approved or certified by the NRC. These models are discussed in Section 3. Wet storage systems have not yet been licensed, and are not discussed in this handbook.

\subsection{References}

1. U.S. Nuclear Regulatory Commission, "Final Generic Environmental Impact Statement [GEIS] on Handling and Storage of Spent Light Water Power Reactor Fuel ," NUREG-0575, August 1979.

2. U.S. Congress, Nuclear Waste Policy Act of 1982, Public Law 97-425 (96 Stat. 2201).

3. U.S. Nuclear Regulatory Commission, "Requirements of Licensee Actions Regarding the Disposition of Spent Fuel Upon Expiration of Reactor Operating Licenses," Federal Register, 49 FR 34688, August 31, 1984.

4. U.S. Nuclear Regulatory Commission, "Storage of Spent Fuel in NRC-Approved Storage Casks at Power Reactor Sites," Federal Register, 55 FR 29181, July 18, 1990. 


$$
\begin{aligned}
& \hat{\mathbf{A}}=\text { Site-Specific License } \\
& \mathbf{}=\text { General License }
\end{aligned}
$$

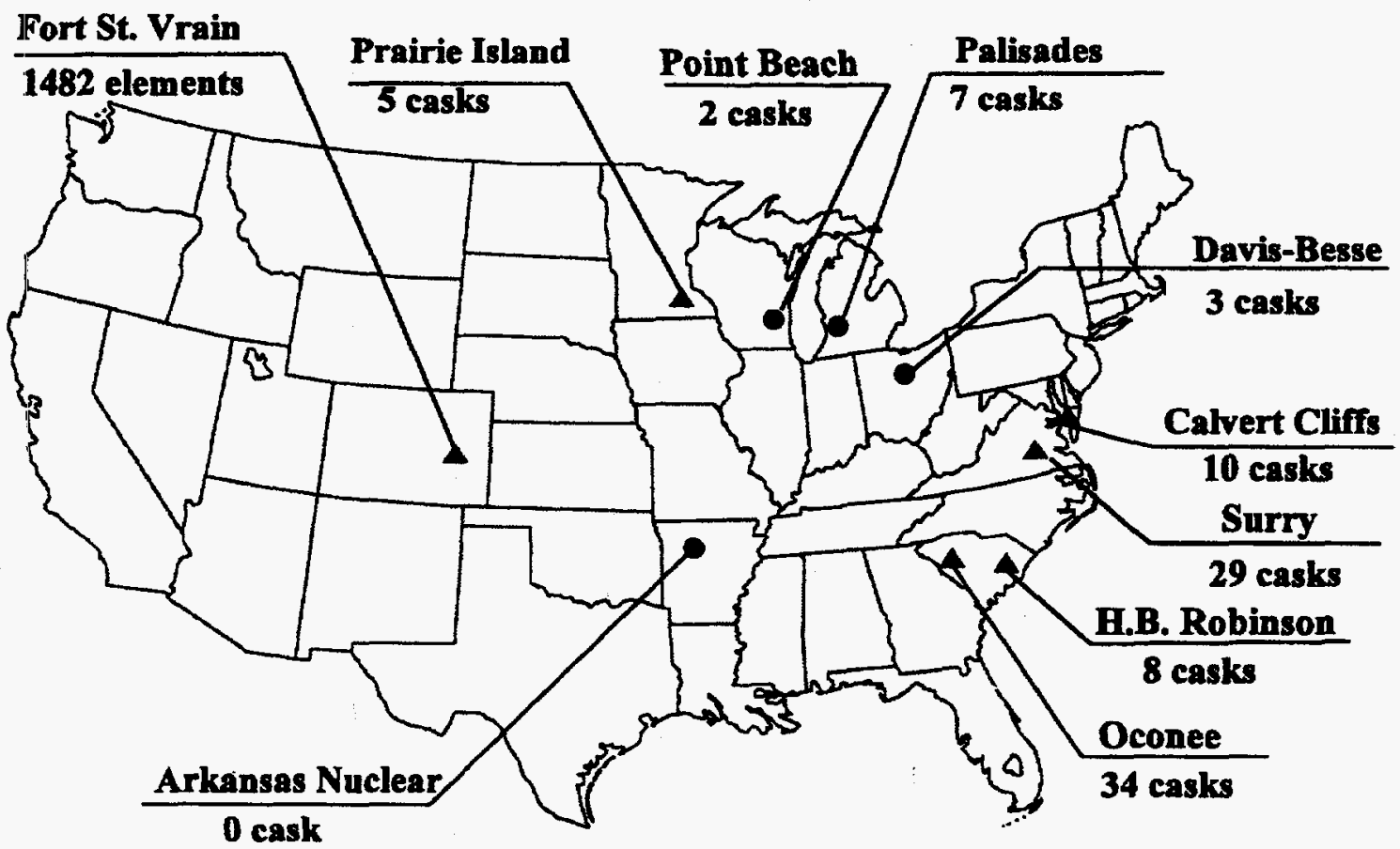

(Data as of September 1996)

Figure 1.3-1 Current U.S. ISFSIs 


$$
\begin{aligned}
& \mathbf{\Delta}=\text { Site-Specific License } \\
& \bullet=\text { General License }
\end{aligned}
$$

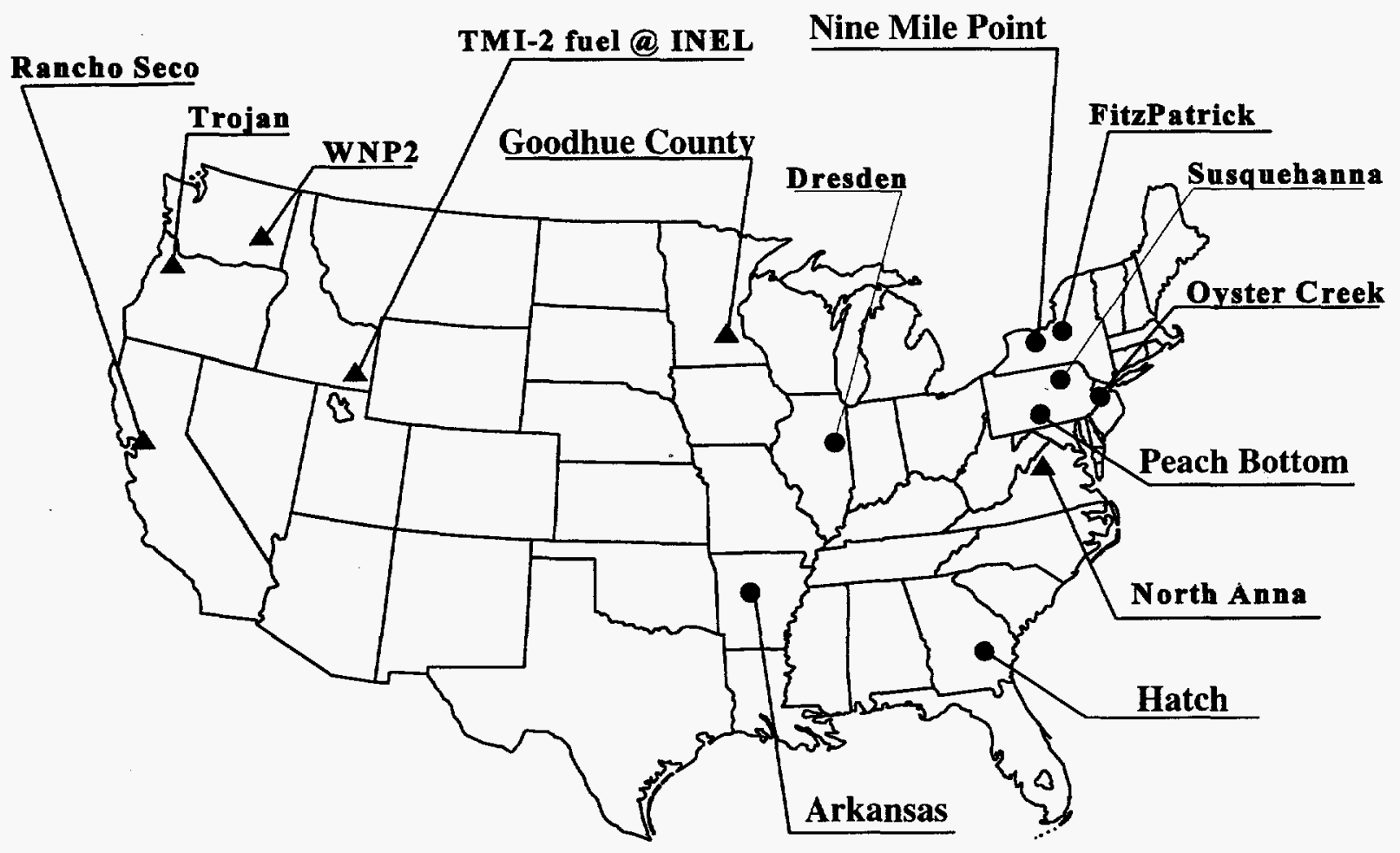

Figure 1.3-2 Potential ISFSIs Needed in Near Future 


\section{DCSS}

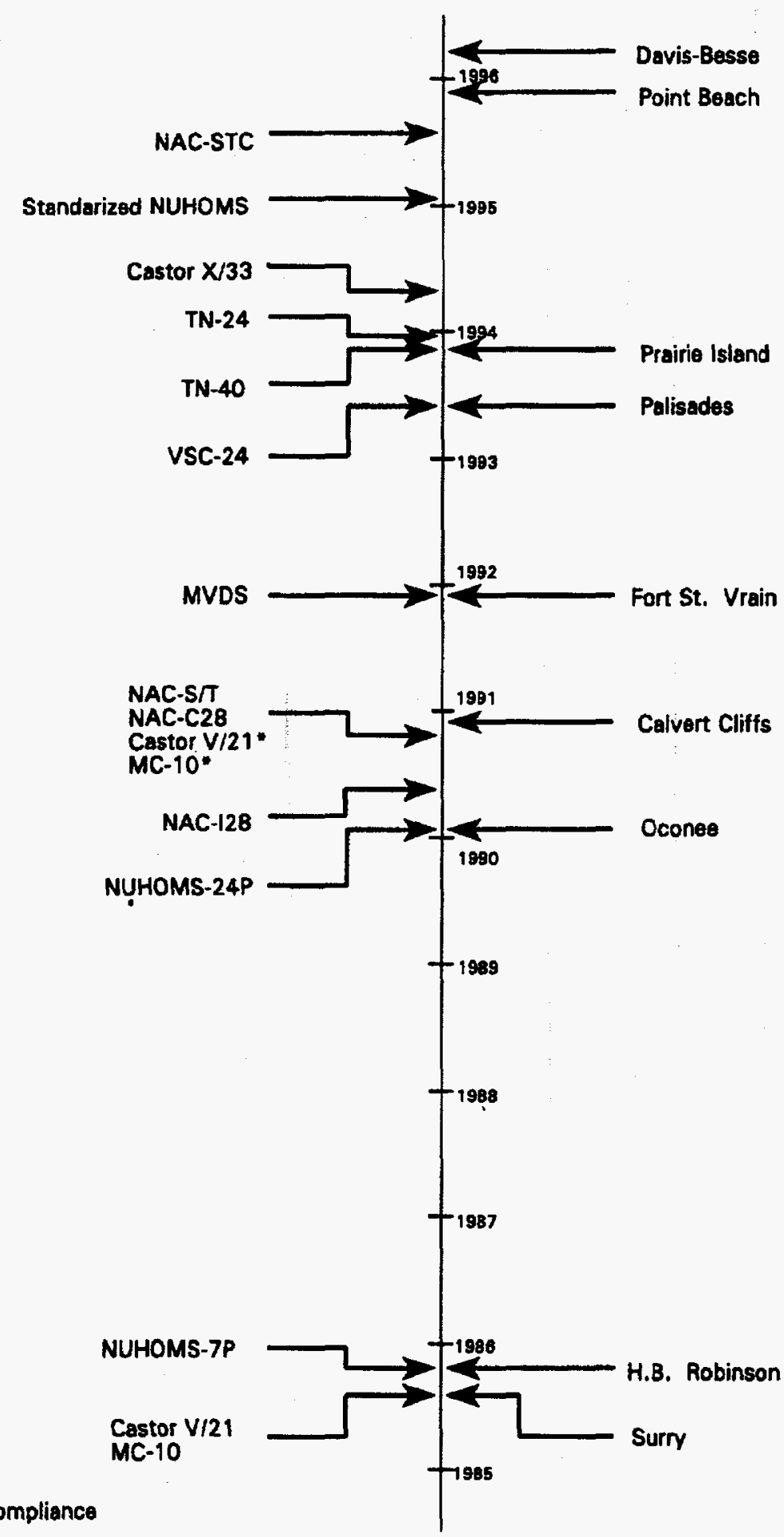

ISFSI

- Certilificate of Compliance

Figure 1.3-3 Time-Line of DCSS and ISFSI Licensing/Operating Dates 


\section{LICENSING PROCESSES}

The requirements for licensing, either for a site-specific or for a general ISFSI, are in 10 CFR Part 72. This section describes the processes involved for obtaining or using both types of licenses, and discusses the advantages and disadvantages of each license.

\subsection{Site-Specific License}

All current site-specific ISFSIs are owned and operated by 10 CFR Part 50 power reactor license holders. However, facilities owned by non-reactor entities may apply for a site-specific license. An approved site-specific ISFSI could be located offsite from a nuclear power plant, and could possibly accept fuel from more than one nuclear power plant.

\subsubsection{License Submittal}

A site-specific ISFSI must meet several licensing requirements similar to a 10 CFR Part 50 power reactor license, in which a safety review and an environmental review must be performed.

Requirements for the site-specific license are described in Subparts A through I of 10 CFR Part 72. In order to receive a site-specific license, the applicant must follow the sequence of events shown in Figure 2.1-1. The applicant must submit to the NRC a license application containing a safety analysis report (SAR), an environmental report (ER), and an emergency plan (EP). The license application must contain the technical information described in 10 CFR 72.24. Some of the requirements for a site-specific license that are reviewed by the NRC are:

- Siting Evaluation Factors (Subpart E) - The site characteristics, including external natural and manmade events, that may directly affect the safety or the environmental impact of the ISFSI.

- General Design Criteria (Subpart F) - The design, fabrication, construction, testing, maintenance, and performance requirements for structures, systems, and components important to safety.

- Quality Assurance (Subpart G) - The planned and systematic actions necessary to provide adequate confidence that a structure, system, or component will perform satisfactorily in service as applied to design, purchase, fabrication, handling, shipping, storing, cleaning, assembly, inspection, testing, operation, maintenance, repair, modification, and decommissioning.

- Physical Protection (Subpart H) - The detailed plans for ISFSI security. 
- Personnel Training (Subpart I) - The program for training, proficiency testing, and certification of ISFSI personnel who operate equipment or controls important to safety.

\subsubsection{NRC Review}

Once the application is received by the NRC, a docket number is assigned, and a notice of receipt of the application is published in the Federal Register $(F R)$. Almost all documents submitted to the NRC are made available for public inspection, except for proprietary information and other classified information (e.g., physical protection details). The $F R$ notice will announce an opportunity for a hearing and will contain a notice of consideration of proposed action.

The NRC reviews the license application and completes an evaluation of potential environmental impacts of the ISFSI in accordance with the National Environmental Policy Act of 1969 (NEPA). The evaluation of potential impacts of the proposed and reasonable alternative actions is documented in either an environmental assessment (EA) or a more extensive environmental impact statement (EIS). Generally, if the ISFSI is to be located at a reactor site, the NRC prepares an EA; if the ISFSI is not located at a reactor site, the NRC prepares an EIS.

After completing its safety review and resolving comments, the NRC issues a safety evaluation report (SER) and the final EA or EIS, and makes a decision about issuing the license. The SER evaluates the SAR, and assesses the technical adequacy of the DCSS or other storage system that will be used. For a license that required preparation of an EA, a positive decision is published as a "finding of no significant impact" (FONSI). For a license that required preparation of an EIS, the decision is documented in a record of decision (ROD) or a Commission ruling. A notice of the licensing action is published in the $F R$, and the applicant receives a site-specific license. A license may be granted for ISFSIl operation up to a period of 20 years.

\subsubsection{License Amendments}

To amend a site-specific license, an application for an amendment is filed with the NRC stating the changes requested and the reasons for those changes. A notice of an opportunity for hearing and a notice of consideration of the proposed amendment is published in the $F R$. However, the NRC may take immediate action on the amendment, without holding a hearing, if it determines that the amendment does not present a genuine issue as to whether the health and safety of the public will be significantly affected. The NRC staff performs a safety evaluation and environmental review to ensure that public health and safety will remain protected by the activities authorized by the amendment and that the environmental impact will remain insignificant. After taking an action on an amendment request, a notice of the action is published in the $F R$. 


\subsection{General License}

A general license is granted by Subpart K of 10 CFR Part 72 to all power reactor licensees to store spent fuel in DCSSs, or casks, ${ }^{1}$ that have obtained certificates of compliance under Subpart L. This allows power reactor licensees to forego redundant environmental reviews and safety evaluations required for site-specific ISFSIs (see Sections 1.2.2 and 1.2.5). The general licensee may only store spent fuel that it is authorized to possess under its power reactor license. Furthermore, the general license is considered as "in addition to," rather than "in lieu of" all regulations in 10 CFR Part 72. Therefore, regulations in Subparts A-I may apply to the general license if applicable and appropriate.

\subsubsection{General License Requirements}

In order to use the general license, a power reactor licensee must follow the sequence of events shown in Figure 2.2-1. Before using a general license, the licensee must perform written evaluations which establish that the conditions of the certificate of compliance have been met in accordance with 10 CFR 72.212 (b)(2), that the cask storage pads and areas have been adequately designed, and that the criteria for radioactive materials in effluents and direct radiation have been met in accordance with $10 \mathrm{CFR}$ 72.104. These conditions entail verification that the reactor site parameters, such as extreme temperatures, seismic design criteria and wind velocities are enveloped by the DCSS design bases.

Other requirements that must be performed or evaluated are written operating procedures and training modules, a preoperational testing and training exercise, identification of any unreviewed safety questions, protection from radiological sabotage, the reactor emergency plan, and ISFSI surveillance requirements. The general licensee must notify the $\mathrm{NRC}$ at least 90 days preceding first-time storage of spent fuel under the general license, and must register the use of each cask with the NRC no later than 30 days after storing spent fuel in that cask.

\subsubsection{Certificate of Compliance}

Dry storage casks that have been issued a certificate of compliance are listed in 10 CFR 72.214, "List of approved spent fuel storage casks." The certificate of compliance for the cask is valid for 20 years. In order to obtain a certificate of compliance for a cask, a vendor must follow the sequence of events shown in Figure 2.2-2.

The applicant must submit to the NRC a license application containing a SAR. Once the application is received by the NRC, a docket number is assigned and the application is made available for public inspection. The NRC reviews the vendor's SAR, prepares a draft SER, a draft EA, and a draft

\footnotetext{
${ }^{1}$ The term "cask" in the language of 10 CFR Part 72, Subparts K and L may be synonymous with dry cask storage system.
} 
certificate of compliance, and publishes a notice of proposed rulemaking to amend 10 CFR 72.214 in the FR. All documents relied upon for the proposed rulemaking are made publicly available, and a period is then opened for public comment. After reviewing the public comments, the NRC prepares the final SER, final EA, and final certificate of compliance. The resolution of comments and final rulemaking to add the cask to the list of approved casks is published in the $F R$, along with the effective date of the final rule (usually 30 days after publication).

The NRC then issues the final SER, certificate of compliance, and technical specifications for the cask to the cask vendor. Technical specifications, functional limits, and operational limits specified in the certificate of compliance may include the following items:

- Fuel specification - the characteristics of the spent fuel that can be stored in the DCSS

- Vacuum and backfill pressures - the vacuum and backfill pressures that must be used in the sealed DCSS

- Dose rates - the maximum allowed dose rates from the cask, transfer systems, and DCSS

- Air exit temperature - the difference between the ambient and vent outlet temperature which must be measured and be within the accepted range for the DCSS design

- Accidental drop - the criteria for inspecting cask and fuel assemblies for damage subsequent to a transfer drop in excess of a specified height

- Contamination limits - the maximum allowed surface contamination limit

- Temperature limits - the ambient temperatures during transfers both within the SFP building and outside the SFP building which must be within the allowable limits of operations

- Criticality control - the procedures to assure subcritical concentration, whether by boron concentrations, poison plates, or other, which must be verified 


\subsection{License Advantages and Disadvantages}

From the perspective of a utility, advantages and disadvantages may be associated with each type of license.

\subsubsection{Site-Specific License}

There are two main advantages associated with the site-specific license. A site-specific license can be used for a plant that plans to decommission, such as Fort St. Vrain (see Section 4.2); a general license, however, is restricted to plants holding operating licenses under 10 CFR Part 50. A second advantage of the site-specific license is that the DCSS may be licensed to store damaged fuel or fuel with special problems, but a DCSS licensed under a general license is restricted to containing intact fuel.

Disadvantages of the site-specific license include the additional cost and time required to obtain the license, due to the more extensive environmental review and DCSS review, and the possibility of public hearings.

\subsubsection{General License}

There are two main advantages associated with the general license. The use of a certified DCSS does not require a new SAR and a new SER. The utility must verify that the requirements for a general license have been satisfied, but the NRC is not required to reexamine the DCSS design. Thus, the use of the general license saves time and licensing costs required for the review of a new DCSS design. A second advantage is that a general license does not require a period of public comment. All public comment occurs during the rulemaking process that a cask undergoes to obtain a certificate of compliance.

There are three disadvantages that may be associated with the general license. First, the license is restricted to plants operating under 10 CFR Part 50. If a plant plans to decommission, it must apply for a site-specific license. Second, the spent fuel must be intact; therefore, damaged fuel cannot be stored. Finally, legal challenges by intervenors on the authority of the general license could require the utility to expend more time and money, as happened in the past to Palisades (see Section 5.3) and Davis-Besse (see Section 5.2).

\subsection{Applicable Regulatory Guides and Additional Guidance}

Regulatory guides and additional guidance that are applicable to the submittal of a license application for the dry storage of spent fuel in an ISFSI are listed below:

- Regulatory Guide 3.48 - "Standard Format and Content for the Safety Analysis Report for an Independent Spent Fuel Storage Installation (Dry Storage)," August 1989 
- Regulatory Guide 3.50 - "Guidance on Preparing a License Application to Store Spent Fuel in an Independent Spent Fuel Storage Installation," September 1989

- Regulatory Guide 3.53 - "Applicability of Existing Regulatory Guides to the Design and Operation of an ISFSI," July 1982

- Regulatory Guide 3.54 - "Spent Fuel Heat Generation in an Independent Spent Fuel Storage Installation," September 1984

- Regulatory Guide 3.60 - "Design of an Independent Spent Fuel Storage Installation (Dry Storage)," March 1987

- Regulatory Guide 3.61 - "Standard Format and Content for a Topical Safety Analysis Report for a Spent Fuel Dry Storage Cask, " February 1989

- Regulatory Guide 3.62 - "Standard Format and Content for the Safety Analysis Report for On-Site Storage of Spent Fuel Storage Casks," February 1989

- Regulatory Guide 3.66 - "Standard Format and Content of Financial Assurance Mechanisms Required for Decommissioning Under 10 CFR Parts 30, 40, 70, and 72," June 1990

- Regulatory Guide 4.2 - "Preparation of Environmental Reports for Nuclear Power Plants," July 1976

- American National Standards Institute/American Nuclear Society - 57.9-1984 American National Standard, "Design Criteria for an Independent Spent Fuel Storage Installation (Dry Storage Type)" 


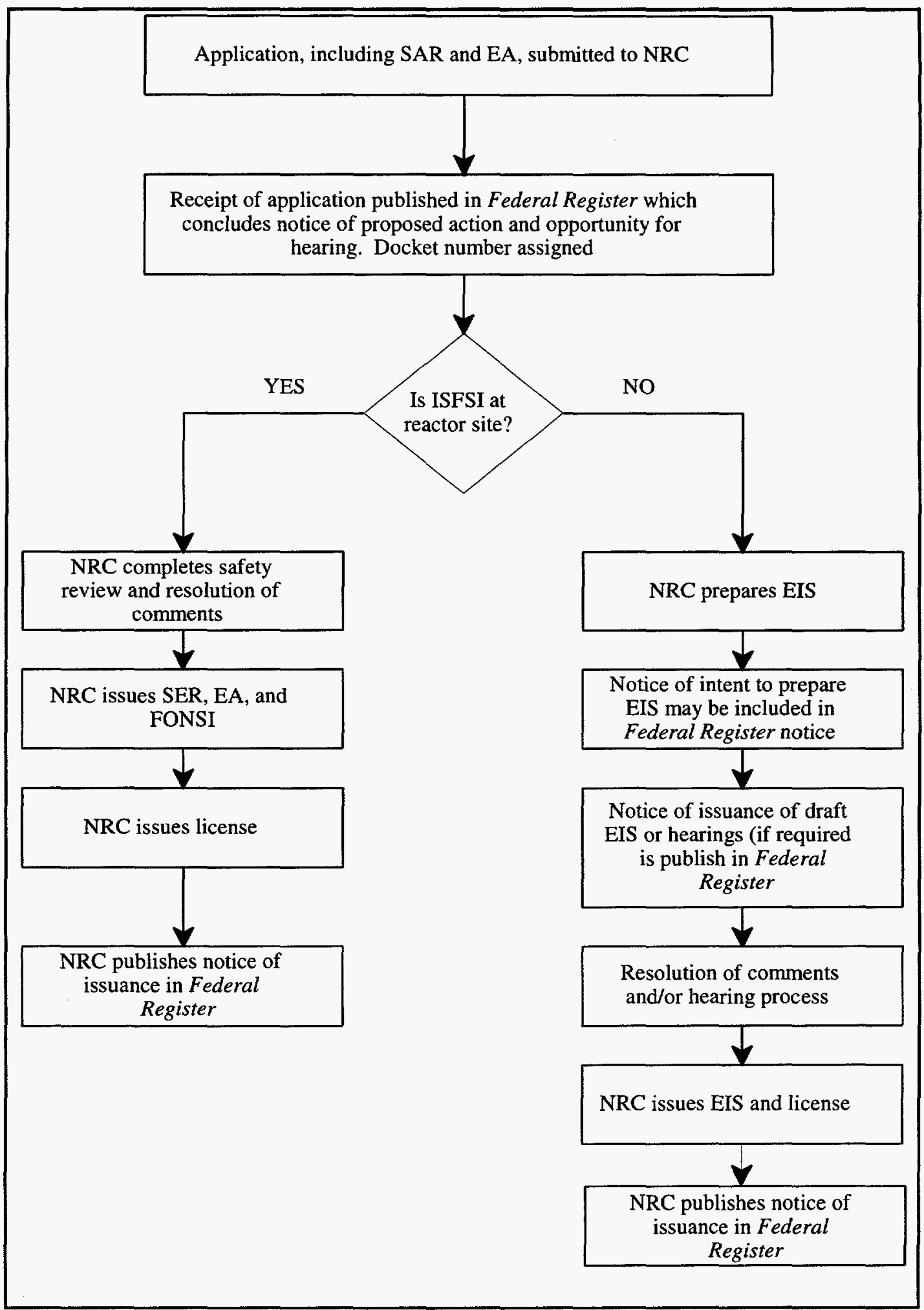

Figure 2.1-1 Site-Specific Licensing Process 


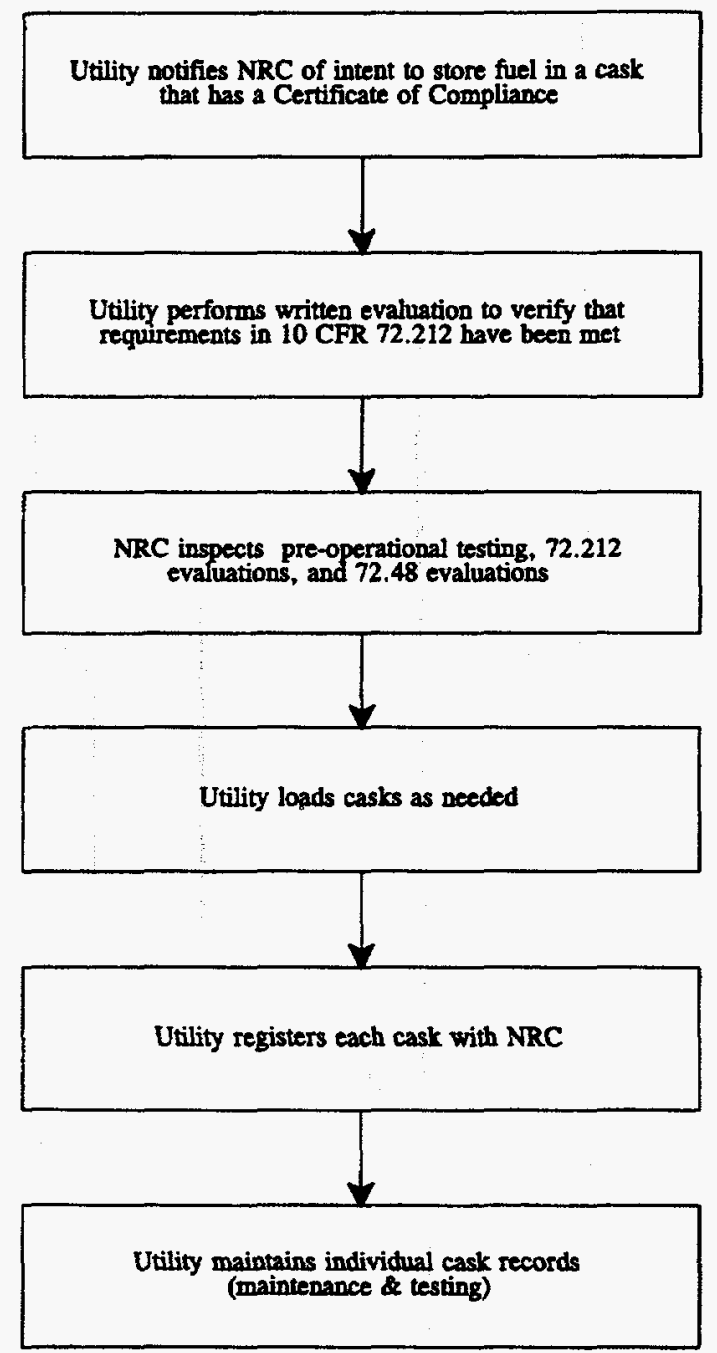

Figure 2.2-1 General Licensing Process 


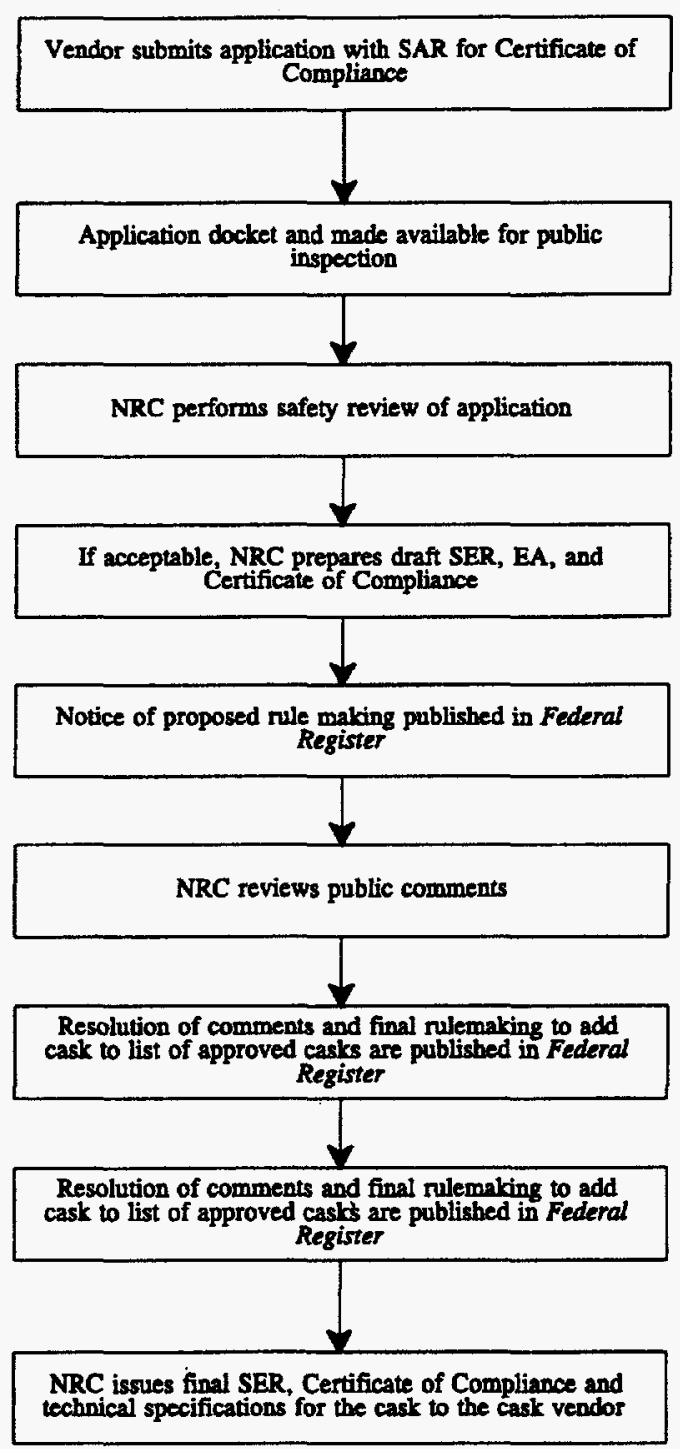

Figure 2.2-2 Certificate of Compliance Issuing Process 



\section{APPROVED DRY CASK STORAGE SYSTEMS}

This section contains a description of those dry cask storage system (DCSS) models currently approved by the NRC to be used at licensed ISFSIs. These models are either approved for use in a site-specific ISFSI or are certified with a certificate of compliance. The descriptions are primarily based on the information contained in the most recent non-proprietary ISFSI safety analysis reports and topical safety analysis reports for each DCSS design. The designs may, however, be changed by the licensee using procedures pursuant to 10 CFR 72.48 (see Section 2.1). A typical DCSS usually consists of either a stand-alone cask, or a canister placed within an overpack. Table 3.1 summarizes approved DCSS models.

It should be noted that this handbook describes all DCSS models licensed for spent fuel storage in ISFSIs. Some DCSSs, called "dual-purpose" casks, however, may be designed by the vendor to be licensed for both transport and storage. Transportation casks must meet independent licensing criteria under 10 CFR Part 71. Furthermore, in the future, cask or canister systems, called "multipurpose" canisters, may be designed for storage, transport, and permanent disposal. 
Table 3-1. Approved Dry Cask Storage Systems

\begin{tabular}{|c|c|c|c|c|}
\hline DCSS Model & Vendor & $\begin{array}{l}\text { License } \\
\text { Date } \\
\end{array}$ & $\begin{array}{l}\text { License/ } \\
\text { Certificate }^{\mathrm{a}}\end{array}$ & ISFSI site(s) \\
\hline Castor V/21 & $\begin{array}{l}\text { General Nuclear Systems, } \\
\text { Inc. }\end{array}$ & $\begin{array}{l}07 / 02 / 86 \\
08 / 17 / 90\end{array}$ & $\begin{array}{l}\text { SNM-2501 } \\
\text { CoC \#1000 }\end{array}$ & Surry \\
\hline Castor $\mathrm{X} / 33$ & $\begin{array}{l}\text { General Nuclear Systems, } \\
\text { Inc. }\end{array}$ & $04 / 22 / 94$ & SNM-2501 & Surry \\
\hline MC-10 & $\begin{array}{l}\text { Westinghouse Electric } \\
\text { Corporation }\end{array}$ & $\begin{array}{l}07 / 02 / 86 \\
08 / 17 / 90\end{array}$ & $\begin{array}{l}\text { SNM-2501 } \\
\mathrm{CoC} \# 1001\end{array}$ & Surry \\
\hline MVDS & $\begin{array}{l}\text { Foster Wheeler Energy } \\
\text { Applications, Inc. }\end{array}$ & $11 / 04 / 91$ & SNM-2504 & Fort St. Vrain \\
\hline $\mathrm{NAC}-\mathrm{S} / \mathrm{T}$ & $\begin{array}{l}\text { Nuclear Assurance } \\
\text { Corporation }\end{array}$ & $08 / 17 / 90$ & $\mathrm{CoC} \# 1002$ & \\
\hline NAC-I28 S/T & $\begin{array}{l}\text { Nuclear Assurance } \\
\text { Corporation }\end{array}$ & $05 / 16 / 90$ & SNM-2501 & Surry \\
\hline $\begin{array}{l}\text { NAC-C28 } \\
\text { S/T }\end{array}$ & $\begin{array}{l}\text { Nuclear Assurance } \\
\text { Corporation }\end{array}$ & $08 / 17 / 90$ & $\mathrm{CoC} \# 1003$ & \\
\hline NAC-STC & $\begin{array}{l}\text { Nuclear Assurance } \\
\text { Corporation }\end{array}$ & $07 / 17 / 95$ & & \\
\hline NUHOMS-7P & $\begin{array}{l}\text { VECTRA Technologies, } \\
\text { Inc. }\end{array}$ & $08 / 13 / 86$ & SNM-2502 & H.B. Robinson \\
\hline $\begin{array}{l}\text { NUHOMS- } \\
24 \mathrm{P}\end{array}$ & $\begin{array}{l}\text { VECTRA Technologies, } \\
\text { Inc. }\end{array}$ & $\begin{array}{l}01 / 29 / 90 \\
11 / 25 / 90\end{array}$ & $\begin{array}{l}\text { SNM-2503 } \\
\text { SNM-2505 }\end{array}$ & $\begin{array}{l}\text { Oconee } \\
\text { Calvert Cliffs }\end{array}$ \\
\hline $\begin{array}{l}\text { Standardized } \\
\text { NUHOMS- } \\
24 \mathrm{P} / 52 \mathrm{~B}^{\mathrm{d}}\end{array}$ & $\begin{array}{l}\text { VECTRA Technologies, } \\
\text { Inc. }\end{array}$ & $01 / 23 / 95$ & $\mathrm{CoC} \# 1004$ & $\begin{array}{l}\text { Davis Besse-(24P) } \\
\text { Oyster Creek (planned 52B) } \\
\text { FitzPatrick (planned 24P) }\end{array}$ \\
\hline $\mathrm{TN}-40$ & Transnuclear, Inc. & $10 / 19 / 93$ & SNM-2506 & Prairie Island \\
\hline $\mathrm{TN}-24$ & Transnuclear, Inc. & $11 / 04 / 93$ & $\mathrm{CoC} \# 1005$ & \\
\hline VSC-24 & Sierra Nuclear Corporation & $05 / 03 / 93$ & CoC\#1007 & $\begin{array}{l}\text { Palisades } \\
\text { Point Beach } \\
\text { Arkansas Nuclear One }\end{array}$ \\
\hline
\end{tabular}

${ }^{a} \mathrm{CoC} \#=$ Certificate of compliance number for general license use. SNM\#=Site-specific license number.

burry has site-specific license and uses some casks which later obtained certificates of compliance.

"The NAC-I28 and -C28 casks are similar. Only the baskets are different. The "I" signifies intact fuel; the " $\mathrm{Cl}$ signifies consolidated fuel.

${ }^{\mathrm{T}}$ The $-24 \mathrm{P}$ and $-52 / \mathrm{B}$ casks are similar. Only the baskets are different. The "P" signifies PWR fuel; the "B" signifies BWR fuel. 


\subsection{Castor V/21: Certificate of Compliance \#1000}

The Castor V/21, made by General Nuclear Systems, Inc., is a metal DCSS designed to vertically store 21 pressurized-water reactor (PWR) spent fuel assemblies (SFAs). The cask is approximately $4.9 \mathrm{~m}(16.0 \mathrm{ft})$ high and $2.4 \mathrm{~m}(7.9 \mathrm{ft})$ in overall diameter. It weighs approximately 98 tonnes (108 tons) when fully loaded. The Castor V/21 was originally approved for use at the site-specific Surry ISFSI, and then later received a certificate of compliance for general use. It is currently in use at the Surry ISFSI. A diagram of the cask is shown in Figure 3.1-1. A photograph of the cask is shown in Figure 3.1-2.

\subsubsection{Cask Body}

The cask body consists of a nodular cast-iron material with a thickness of approximately $37.9 \mathrm{~cm}$ (14.9 in.). The top of the cask is sealed with two stainless steel lids bolted onto the cask, using both metallic and elastomeric $O$-ring seals. The primary and secondary lids are approximately $29 \mathrm{~cm}$ (11.4 in.) and $9 \mathrm{~cm}$ (3.5 in.) thick, respectively. Gamma shielding is provided by the wall of the cask, and neutron shielding is provided by two concentric rows of polyethylene rods incorporated into the cask wall. The inside of the cask and sealing surfaces have a nickel coating for corrosion protection. The internal cavity is filled with helium for heat transfer and corrosion protection. The external surface is covered with 73 heat transfer fins which run circumferentially around the cask. An epoxy resin coating protects the outside surface in the fin region. Four trunnions are connected to the cask body for lifting and rotating the cask.

The inside of the cask contains a fuel basket structure comprised of 21 square tubes of welded stainless steel and borated (for criticality control) stainless steel plates. A photograph of the basket is shown in Figure 3.1-3.

\subsubsection{Operations}

The major operating systems are those required for handling and transferring the fuel from the SFP to the ISFSI for storage, and likewise for removing the fuel from the ISFSI. The cask is loaded underwater in the SFP, as shown in Figure 3.1-4, and the primary lid is placed on the cask. The cask is then lifted to the pool surface, and the seal of the primary lid is fastened and tested for tightness. After being lifted out of the SFP, the cask is pumped empty and vacuum dried. The secondary lid is fastened, the seals are tested, and the space between the lids is pressurized with helium. Next, a pressure-sensing device is mounted in the secondary lid, a protective transport impact limiter is installed, and the outside surface is decontaminated. The cask is then transferred to the ISFSI site and is set in place on the concrete pad. The seal pressure-monitoring system is externally connected and will notify plant operators of a loss of seal integrity. Unloading procedures are similar to the loading procedures (in reverse). 
The cask is a totally passive system with natural cooling sufficient to maintain safe fuel cladding temperatures. The cask wall provides adequate shielding, and no radioactive products are released under any credible conditions. Normal radiation survey monitoring of the ISFSI is also performed.

\subsubsection{Reference Documents}

General Nuclear Systems, Inc., "Topical Safety Analysis Report for the Castor V/21 Cask Independent Spent Storage Installation (Dry Storage)", Rev. 2A, June 1987. (Docket 72-1000)

Virginia Electric \& Power Company, "Safety Analysis Report for Surry Power Station Dry Cask Independent Spent Fuel Storage Installation," Rev. 7, 1994. (Docket 72-2)

U.S. Nuclear Regulatory Commission, Office of Nuclear Material Safety and Safeguards, "Safety Evaluation Report of Surry Dry Cask Independent Spent Fuel Storage Installation," May 1986.

(Docket 72-2) 


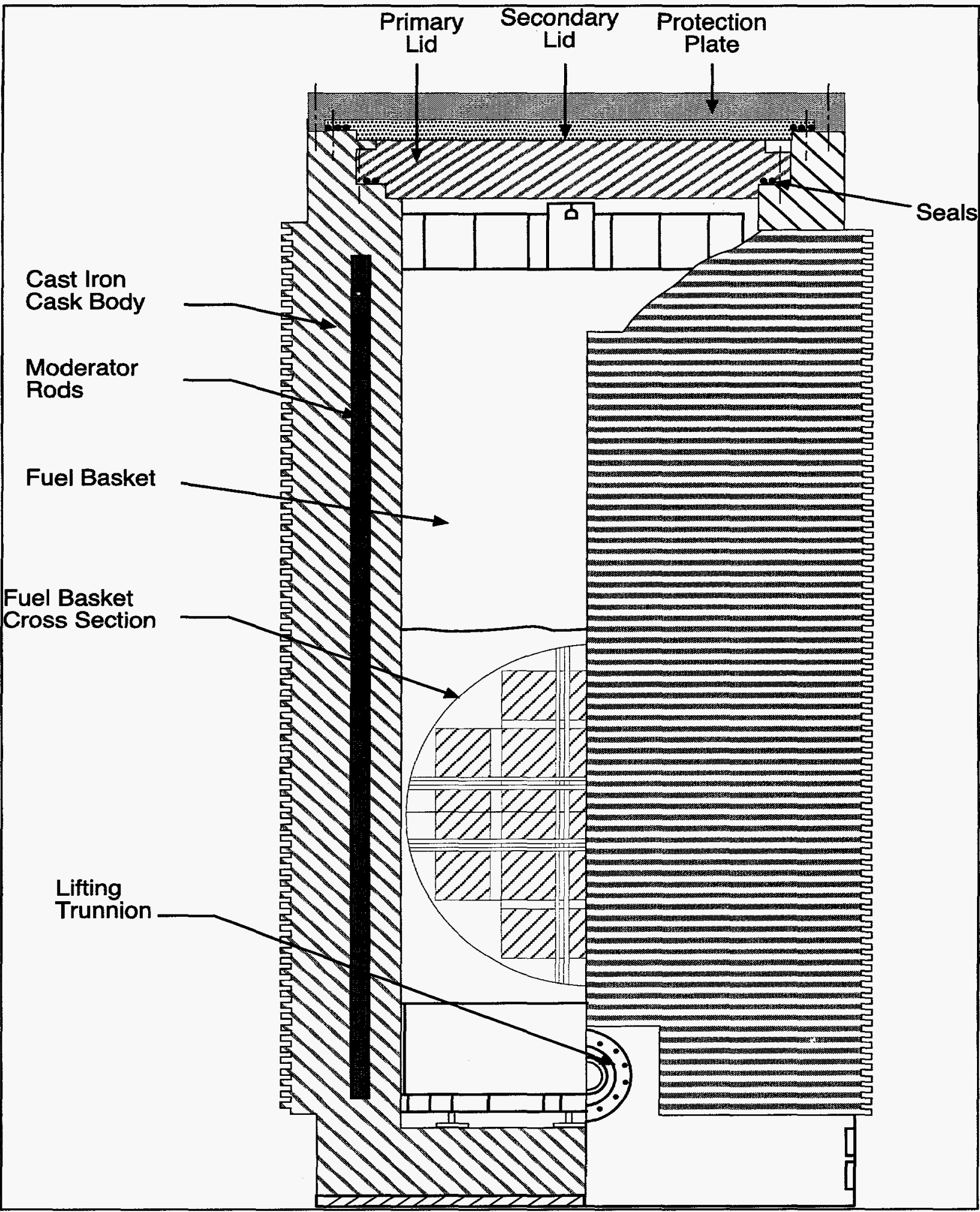

Figure 3.1-1 Diagram of the Castor V/21 


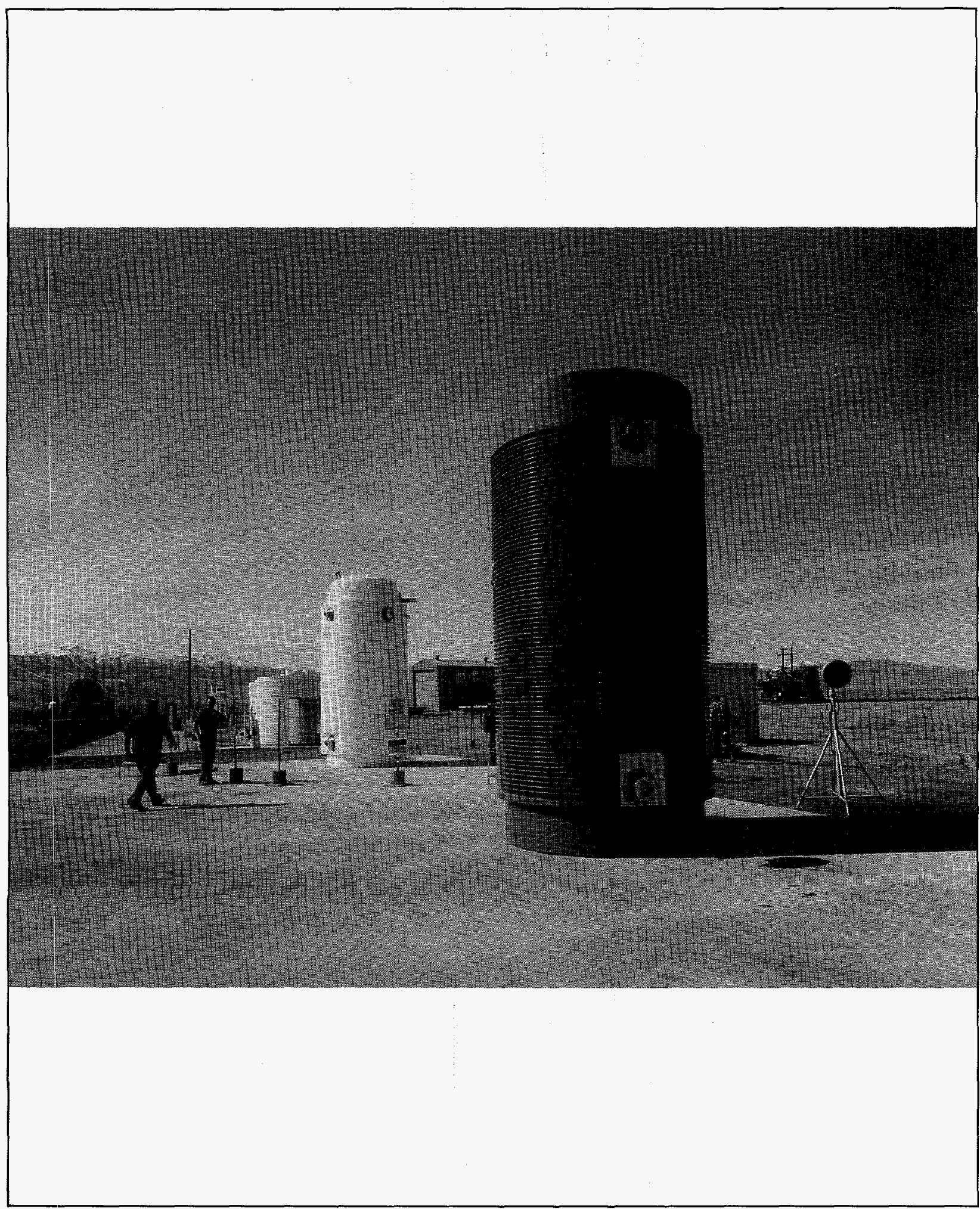

Figure 3.1-2 Photograph of the Castor V/21 


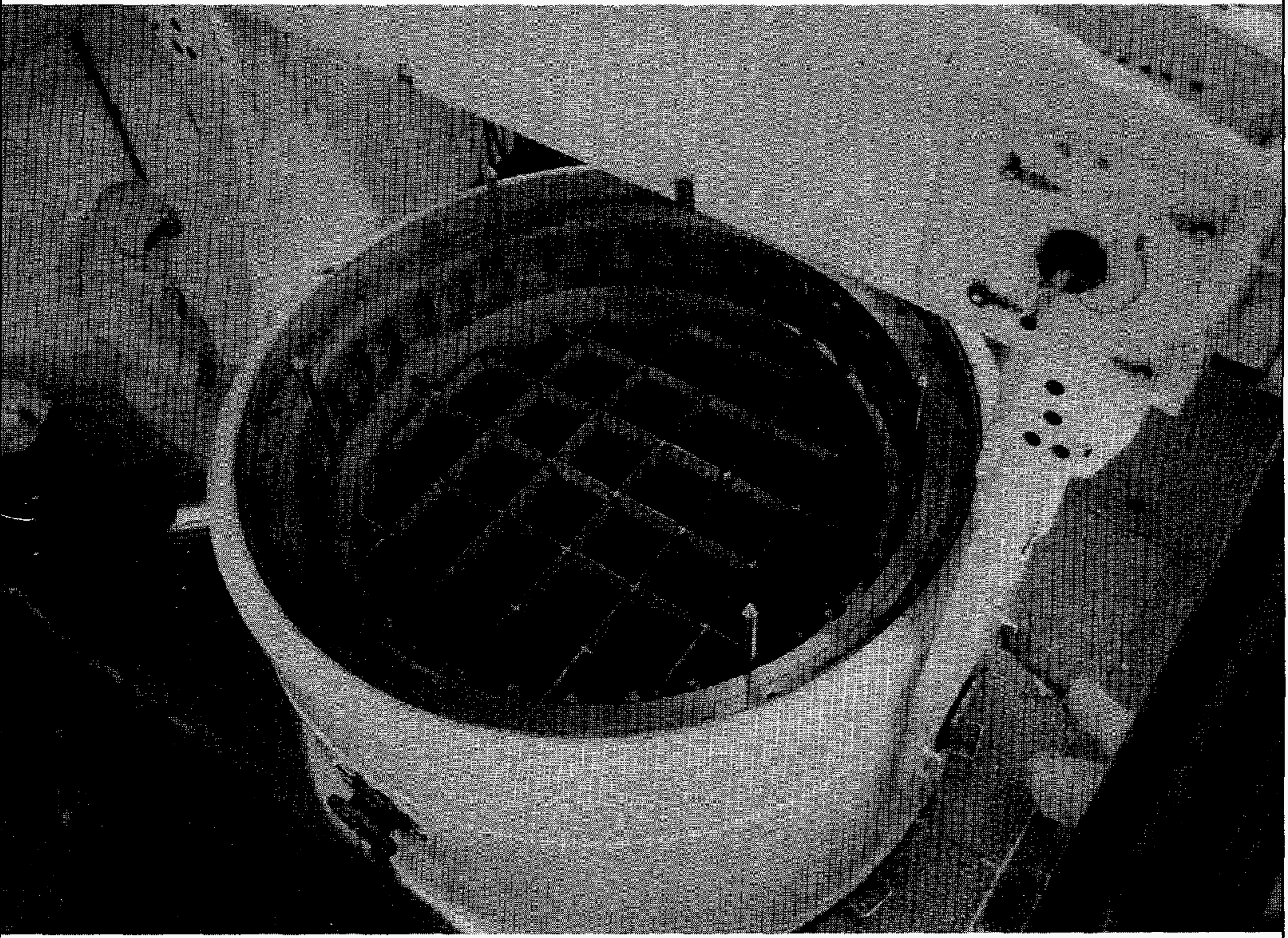

Figure 3.1-3 Photograph of Fuel Basket Inside the MC-10 


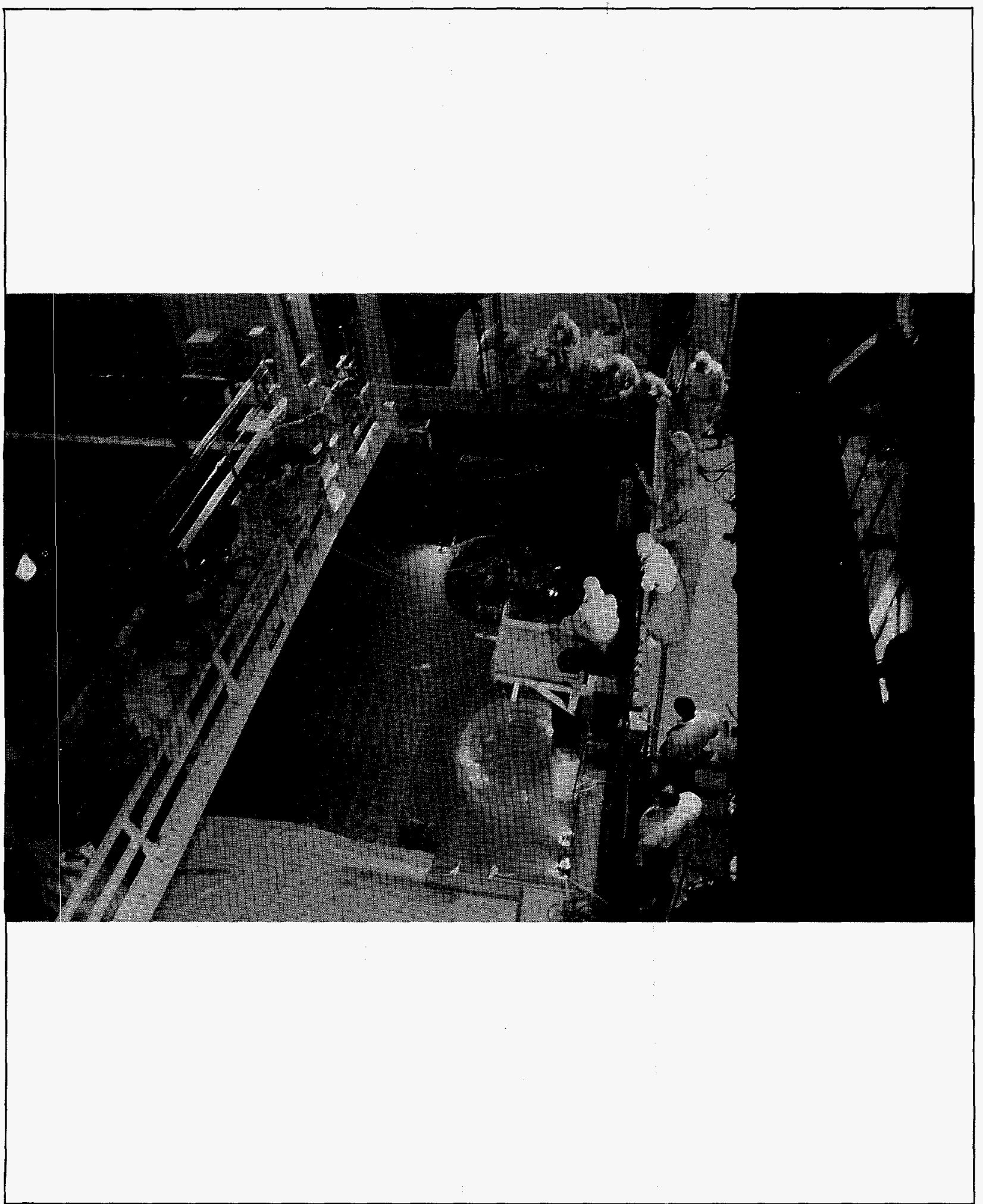

Figure 3.1-4 Photograph of Castor V/21 in the Surry Power Station SFP 


\subsection{Castor $\mathrm{X} / 33$}

The Castor X/33, made by General Nuclear Systems, Inc., is a metal DCSS designed to vertically store 33 PWR SFAs. It evolves from the Castro V/21 design (see Section 3.1). The cask is approximately $4.8 \mathrm{~m}(15.8 \mathrm{ft})$ high and $2.4 \mathrm{~m}(7.8 \mathrm{ft})$ in overall diameter. It weighs approximately 107 tonnes (118 tons) when fully loaded. The Castor X/33 is currently used at the Surry ISFSI. A diagram of the cask is shown in Figure 3.2-1.

\subsubsection{Cask Body}

The cask body consists of a ductile cast-iron material with a thickness is $30.5 \mathrm{~cm}$ (12 in.). The top of the cask is sealed with two stainless steel lids bolted onto the cask, using both metallic and elastomeric O-ring seals. The primary and secondary lids are $26 \mathrm{~cm}$ (10 in.) and $8 \mathrm{~cm}$ (3 in.) thick, respectively. Gamma shielding is provided by the wall of the cask, and neutron shielding is provided by a single row of polyethylene rods incorporated into the cask wall. The inside of the cask and sealing surfaces have a nickel coating for corrosion protection. The internal cavity is filled with helium for heat transfer and corrosion protection. An epoxy resin coating protects the outside surface of the cask. Four trunnions are connected to the cask body for lifting and rotating the cask.

The inside of the cask contains a fuel basket structure comprised of 33 square tubes of welded stainless steel and borated (for criticality control) stainless steel plates.

\subsubsection{Operations}

The major operating systems are those required for handling and transferring the fuel from the SFP to the ISFSI for storage, and likewise for removing the fuel from the ISFSI. The cask is loaded underwater in the SFP and the primary lid is placed on the cask. The cask is then lifted to the pool surface, and the seal of the primary lid is fastened and tested for tightness. After being lifted out of the SFP, the cask is pumped empty and vacuum dried. The secondary lid is fastened, the seals are tested, and the space between the lids is pressurized with helium. Next, a pressure-sensing device is mounted in the secondary lid, a protective transport impact limiter is installed, and the outside surface is decontaminated. The cask is then moved to the ISFSI site and is set in place on the concrete pad. The seal pressure-monitoring system is externally connected and will notify plant operators of a loss of seal integrity. Unloading procedures are similar to the loading procedures (in reverse).

The cask is a totally passive system with natural cooling sufficient to maintain safe fuel cladding temperatures. The cask wall provides adequate shielding, and no radioactive products are released under any credible conditions. Normal radiation survey monitoring is also performed. 


\subsubsection{Reference Documents}

General Nuclear Systems, Inc., "Topical Safety Analysis Report for the Castor X Cask for an Independent Spent Fuel Storage Installation (Dry Storage)," Rev. 4, September 1990. (Docket 721018)

U.S. Nuclear Regulatory Commission, Office of Nuclear Material Safety and Safeguards, "Safety Evaluation Report for the Topical Safety Analysis Report for the Castor X/33 Spent Fuel Storage Cask," April 1994. (Docket 72-1018)

Virginia Electric \& Power Company, "Safety Analysis Report for Surry Power Station Dry Cask Independent Spent Fuel Storage Installation," Rev. 7, 1994. (Docket 72-2) 


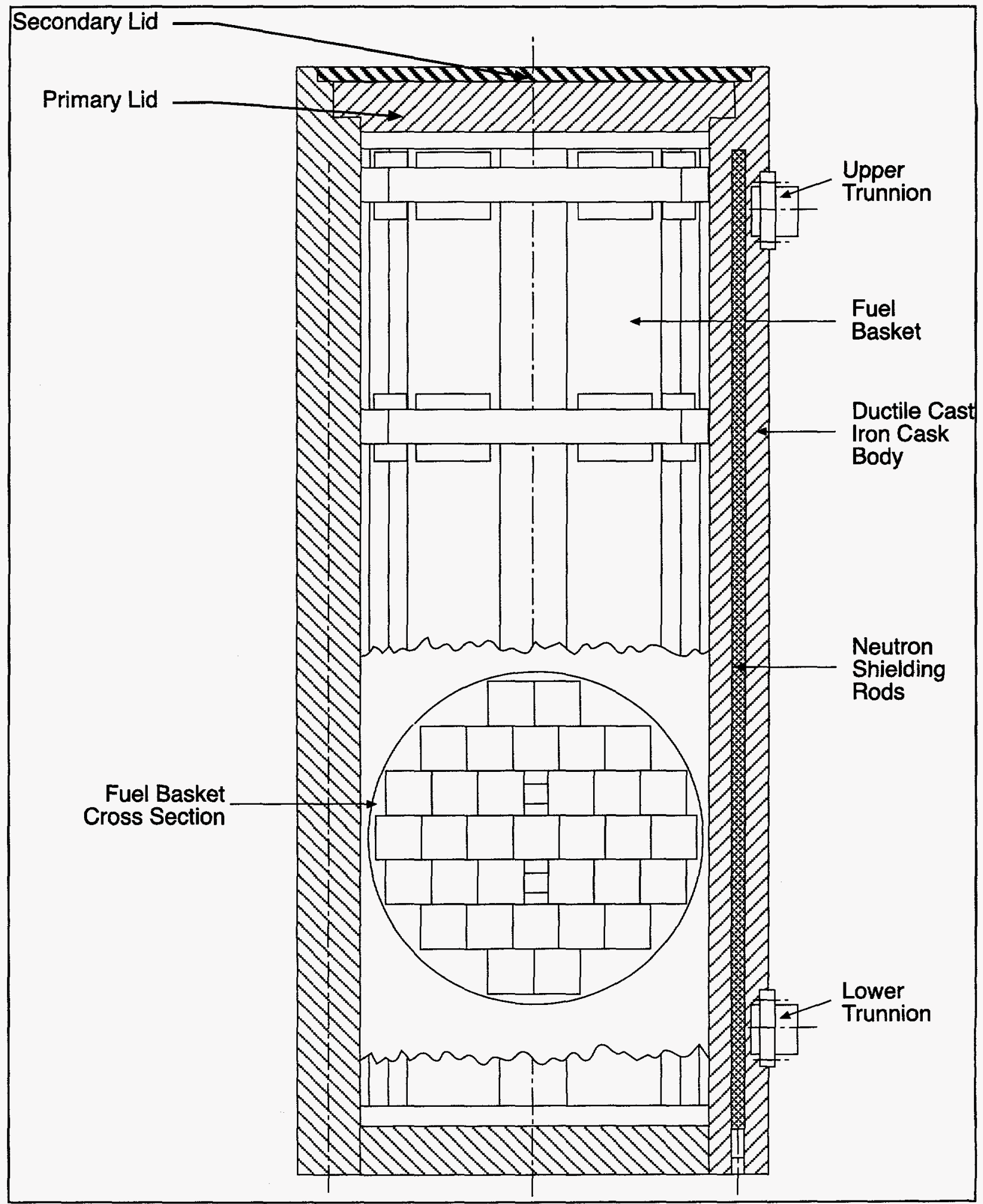

Figure 3.2-1 Diagram of the Castor X/33 


\subsection{MC-10: Certificate of Compliance \# 1001}

The MC-10, made by Westinghouse Electric Corporation, is a metal DCSS designed to vertically store 24 PWR SFAs. The cask is approximately $4.8 \mathrm{~m}(15.7 \mathrm{ft})$ high and $2.7 \mathrm{~m}(8.9 \mathrm{ft})$ in overall diameter. It weighs approximately 103 tonnes (113 tons) when fully loaded. The MC-10 was originally approved for use at the site-specific Surry ISFSI, and then later received a certificate of compliance for general use. It is currently in use at the Surry ISFSI. A diagram of the cask is shown in Figure 3.3-1. A photograph of the cask is shown in Figure 3.3-2.

\subsubsection{Cask Body}

The cask consists of a low alloy steel shielded container with forged steel walls and a bottom that are approximately $25 \mathrm{~cm}$ (10 in.) and $28 \mathrm{~cm}$ (11 in.) thick, respectively. Four covers are used to seal the top end of the cask cylinder. A low alloy steel shield cover, approximately $23 \mathrm{~cm}$ (9 in.) thick, with a metallic O-ring seal, provides the initial seal and shielding following fuel loading. A carbon steel cover, approximately $9 \mathrm{~cm}$ ( $3.5 \mathrm{in}$.) thick, with a metallic O-ring seal, provides the primary containment seal. A seal lid provides a secondary containment seal. The fourth cover, containing a BISCO NS-3 neutron-absorbing material, is welded over the first two seals to provide seal redundancy. The inside surface of cask is thermally sprayed with aluminum to provide corrosion protection. The internal cavity is also filled with helium for heat transfer and corrosion protection. Twenty-four carbon steel heat transfer fins are welded axially along the outside of the cask wall. Carbon steel plates are welded between the fins to provide an approximately $6.4 \mathrm{~mm}(0.25 \mathrm{in})$ outer protective skin, approximately $8 \mathrm{~cm}$ ( 3 in.) from the cask wall. Neutron shielding is provided by a layer of BISCO NS-3 cured in the cavity between the cask wall and outer protective skin. Four trunnions are connected to the cask body for lifting and rotating the cask.

The inside of the cask contains a fuel basket that is a grid structure constructed of aluminum. Each of 24 removable cell storage locations consists of a stainless steel enclosure, borated neutron poison plates (for criticality control), and steel wrappers.

\subsubsection{Operations}

The major operating systems are those required for handling and transferring the fuel from the SFP to the ISFSI for storage, and likewise for removing the fuel from the ISFSI. The cask is loaded underwater in the SFP and the shield cover is placed on the cask. After being lifted out of the SFP, the shield cover is bolted in place, and the cask is drained, pressurized with helium, and decontaminated. Next, a pressure-monitoring device is mounted in the primary seal, the primary lid is bolted in place, and the cask is vacuum dried and repressurized with helium. The seal lid is then bolted to the primary lid, and the neutron shield lid is welded to the cask rim. Following 
decontamination of the outer surface, the cask is transferred to the ISFSI site and set in place on the concrete pad. Unloading procedures are similar to the loading procedures (in reverse).

The cask is a totally passive system with natural cooling sufficient to maintain safe fuel cladding temperatures. The cask wall provides adequate shielding, and no radioactive products are released under any credible conditions. Normal radiation survey monitoring and daily monitoring of internal helium pressure is performed.

\subsubsection{Reference Documents}

Westinghouse Electric Corporation, "Topical Safety Analysis Report for the Westinghouse MC-10 Cask for an Independent Spent Fuel Storage Installation (Dry Storage)," Rev. 2A, November 1987. (Docket 72-1001)

U.S. Nuclear Regulatory Commission, Office of Nuclear Material Safety and Safeguards, "SER of Westinghouse Electric Corporation's Topical Safety Analysis Report for the Westinghouse MC-10 Cask for an Independent Spent Fuel Storage Installation (Dry Storage)," Rev. 1, September 1987. (Docket 72-1001)

Virginia Electric \& Power Company, "Safety Analysis Report for Surry Power Station Dry Cask Independent Spent Fuel Storage Installation," Rev. 7, 1994. (Docket 72-2) 


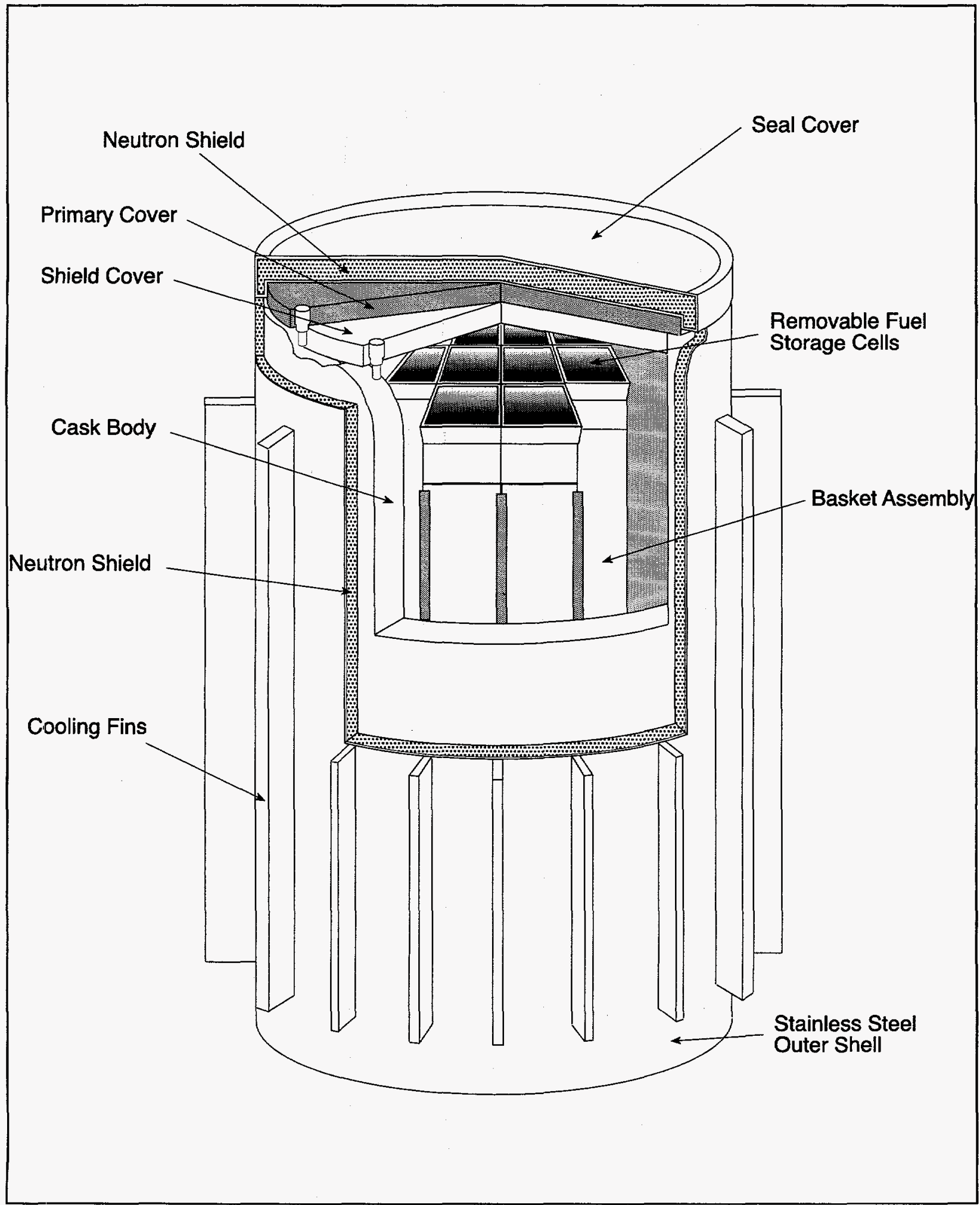

Figure 3.3-1 Diagram of the MC-10 


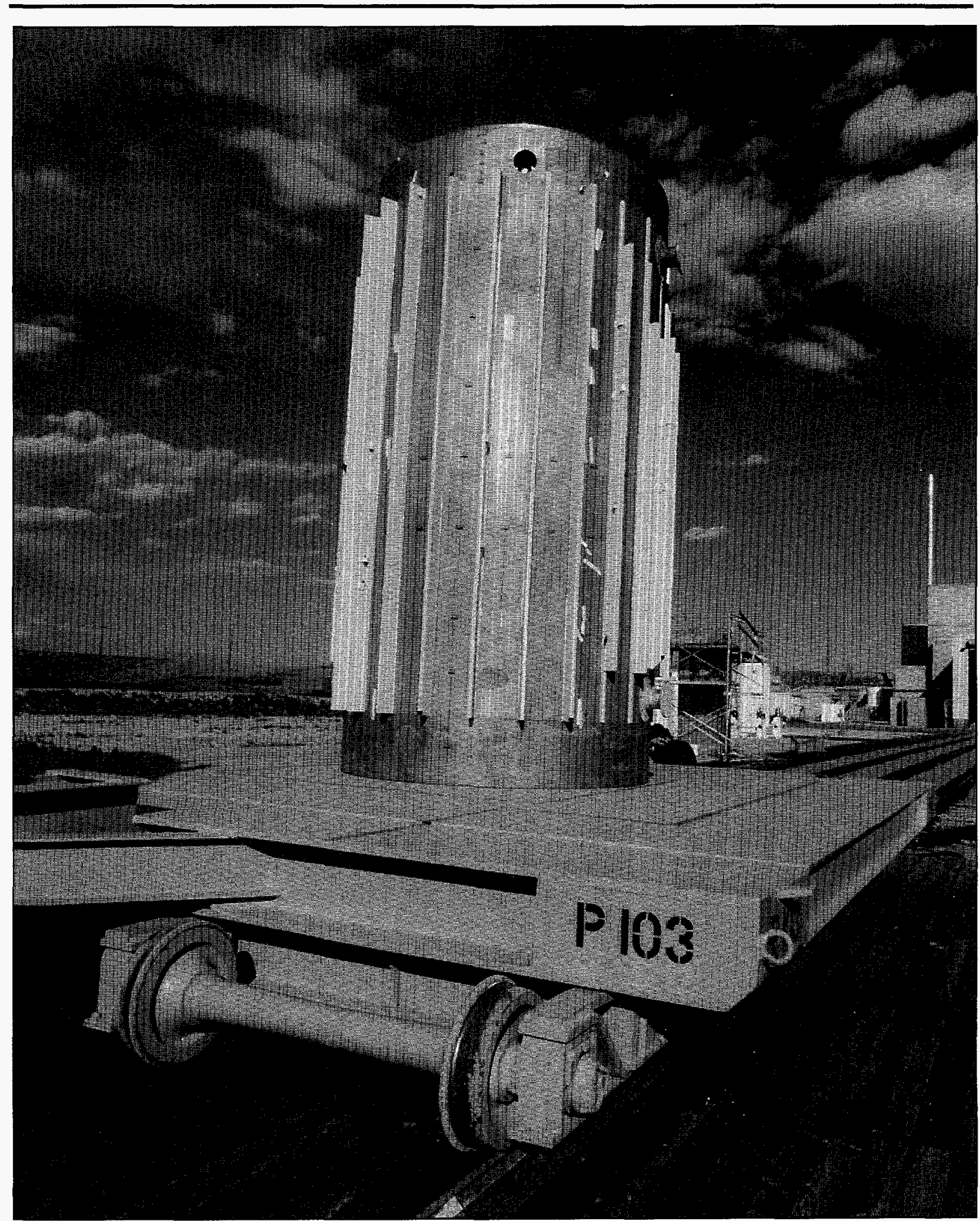

Figure 3.3-2 Photograph of the MC-10 


\subsection{Modular Vault Dry Store (MVDS) System}

The modular vault dry store (MVDS) system, made by Foster Wheeler Energy Applications, Inc., is a concrete vault DCSS designed to vertically store 1482 high-temperature gas-cooled (HTGC) spent fuel, 37 reflector elements, and 6 neutron source elements from the Fort St. Vrain power station (see Section 4.2), which is being decommissioned. A diagram of the MVDS system is shown in Figure 3.4-1. A photograph of the MVDS system is shown in Figure 3.4-2.

The MVDS system is unique among other licensed ISFSIs. It is the only installation which has the capability to handle and transfer HTGC fuel from 10 CFR Part 71 approved shipping casks at the actual ISFSI site. It is also equipped to conduct decontamination operations, and it uses a monitored nitrogen (rather than helium) cover gas.

\subsubsection{MVDS System}

The MVDS system consists of a foundation structure supporting a matrix of six concrete vault modules (VMs), one neutron source storage well, two standby storage wells, six charge face structures (CFSs) forming the roofs over the VMs, and a transfer cask reception bay, with a steel canopy above

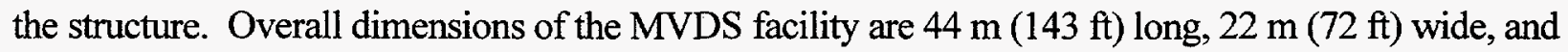
$25 \mathrm{~m}(81 \mathrm{ft})$ high. Each concrete VM contains a matrix of 45 storage positions capable of storing six fuel storage containers (FSCs) in each position. The neutron storage well, which is separated from the VMs, is capable of storing six neutron source elements and can be individually sealed. The two standby wells, which is are separated from the VMs, are capable of storing failed FSCs and can be individually sealed. Neutron and gamma shielding is provided by the concrete mass of the ISFSI. Criticality is maintained by the inherent geometry of the system.

\subsubsection{Fuel Storage Container (FSC)}

The FSC consists of a cylindrical carbon steel tube body with an exterior aluminum spray coating, $\mathrm{O}-$ ring seals, and a sealed lid which is placed on the tube flange. The FSC can hold 6 fuel elements or 12 reflector elements. The top of the FSC is shielded by a plug placed in the CFS above the FSC during storage.

\subsubsection{MVDS Crane}

The MVDS crane is an overhead gantry-type crane which can access the entire charge hall. It lifts the transfer cask (TC), the container handling machine (CHM), and the shield plug handling devices. 


\subsubsection{Container Handling Machine}

The CHM is a fully shielded machine used to raise and lower the FSCs to the TC and vault storage locations. It is moved over the CFS by the MVDS crane. The CHM consists of a main shield tube, a single-failure-proof raise/lower mechanism, and an FSC grapple by which an FSC can be raised or lowered. There is also an individual fuel element grapple which can be used to lift fuel elements in the standby storage well during off-normal and accident operations.

\subsubsection{Operations}

The major operating systems are those required for handling and transferring the FSC from the TC into MVDS storage position, and likewise for removing the FSCs. In the reactor building, the fuel elements are loaded into the FSC and the TC is lowered back onto the trailer. The TC is received in the MVDS in the transfer cask reception bay. The TC is lifted by the MVDS crane and positioned in the cask load/unload port. The FSC is then removed by the CHM which in turn is lifted and moved by the MVDS crane over the CFS of the storage vault. Once the CHM reaches the desired position above the CFS, the crane lowers the CHM to the CFS, and the FSC can be inserted through the hole in the CFS into the VM. Unloading procedures are similar to the loading procedures (in reverse).

The decay heat is removed passively by ambient air flowing across the outside of the FSCs. The air flows into the vault module through a mesh-covered inlet duct and exits through a reinforced concrete exhaust stack covered by a steel canopy.

\subsubsection{Reference Documents}

Public Service Company of Colorado (PSC), "Safety Analysis Report - Fort St. Vrain Independent Spent Fuel Storage Installation," Rev. 6, December 1995. (Docket 72-9)

Foster Wheeler Energy Applications Inc., "Topical Report for the Foster Wheeler Modular Vault Dry Store for Irradiated Nuclear Fuel," ES 86/20, Rev. 1, October 1987. (Docket 72-1017)

U.S. Nuclear Regulatory Commission, Office of Nuclear Material Safety and Safeguards, "SER for Public Service Company of Colorado's Safety Analysis Report for FSV Independent Spent Fuel Storage Installation," August 30, 1991. (Docket 72-9)

U.S. Nuclear Regulatory Commission, Office of Nuclear Material Safety and Safeguards, "SER for Foster Wheeler Energy Applications, Inc. Modular Vault Dry Store Topical Report," Rev. 1, March 22, 1988. (Docket 72-1017) 


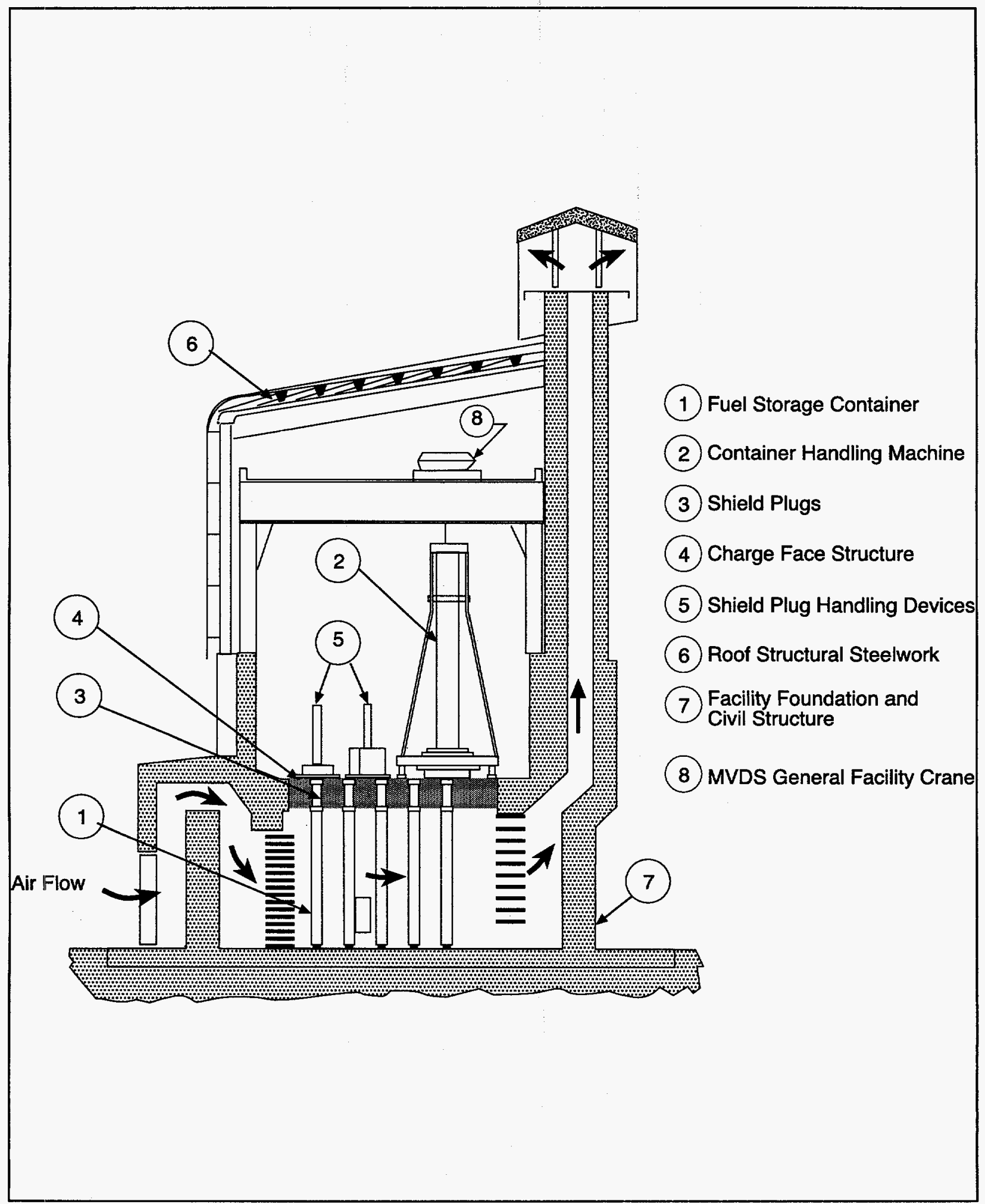

Figure 3.4-1 Diagram of the MVDS System 


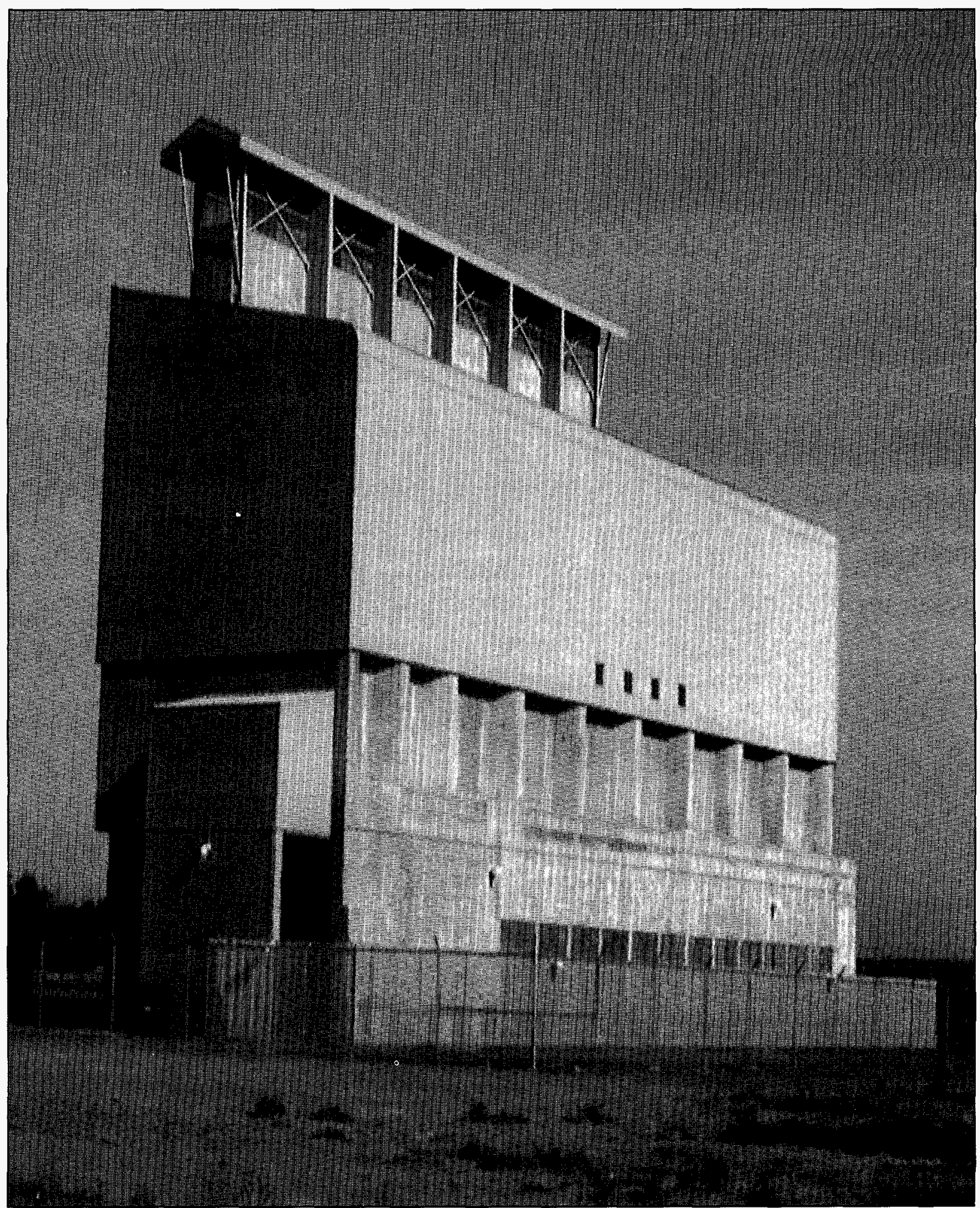

Figure 3.4-2 Photograph of the MVDS System 


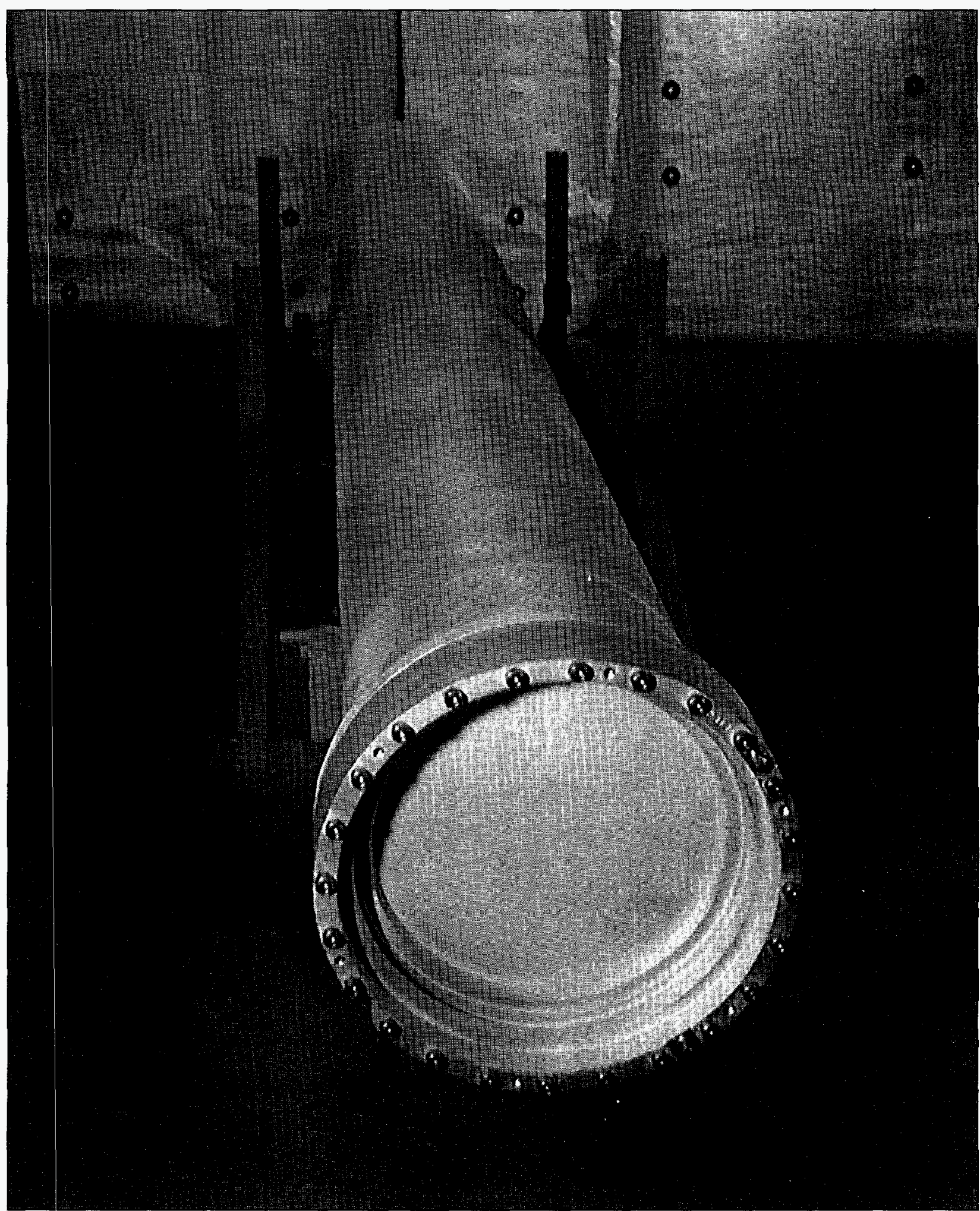

Figure 3.4-3 Photograph of a MVDS FSC 


\subsection{NAC-S/T: Certificate of Compliance \# 1002}

The NAC-S/T cask, made by the Nuclear Assurance Corporation, is a metal DCSS designed to vertically store 26 PWR SFAs. The cask is approximately $4.6 \mathrm{~m}(15.1 \mathrm{ft})$ high and $2.4 \mathrm{~m}(7.9 \mathrm{ft})$ in diameter. It weighs less than 113 tonnes (125 ton) when loaded with SFAs, contained water, and lifting yoke. The NAC-S/T currently is not in use at any existing ISFSIs.

Three other similar variations (different basket designs) of the general NAC-S/T design have been licensed or approved. The NAC-I28 and NAC-C28 have fuel baskets designed to store 28 SFAs (see Sections 3.6 and 3.7). The NAC-STC is designed to be licensed for both storage and transportation (see Section 3.8). A diagram of the general cask design is shown in Figure 3.5-1.

\subsubsection{Cask Body}

The cask body consists of a cylindrical, multi-wall construction of stainless steel components. It has an approximately $3.8 \mathrm{~cm}$ (1.5 in.) thick inner shell and a $6.7 \mathrm{~cm}$ (2.6 in.) thick outer shell of stainless steel separated by $8.1 \mathrm{~cm}$ (3.2 in.) of poured-in-place chemical lead. The inner and outer shell are connected to each other on both ends by austenitic stainless steel rings and plates. The upper end of the cask is sealed by a stainless steel bolted closure lid which is approximately $16.5 \mathrm{~cm}(6.5 \mathrm{in}$.) thick in the edge flange region and has a $2.5 \mathrm{~cm}$ (1 in.) thick inner closure plate and a $14 \mathrm{~cm}(5.5 \mathrm{in}$.) thick outer closure plate. The closure plates are separated by $5 \mathrm{~cm}(2 \mathrm{in}$.) of lead. The closure lid uses a double-barrier seal system with two metallic O-rings seals. A $7.6 \mathrm{~cm}$ (3 in.) thick neutron shield cap encased in stainless steel is placed on top of the cask and may be welded to the cask body. Gamma shielding is provided by the lead wall, and neutron is provided by a $17.8 \mathrm{~cm}(7 \mathrm{in}$.) thick layer of a poured-in-place solid borated synthetic polymer which surrounds the outer shell along the cavity region, and is enclosed by a $6.4 \mathrm{~mm}(0.25 \mathrm{in})$ thick stainless steel shell with end plates. The bottom of the cask is sealed by a $15.2 \mathrm{~cm}$ ( 6 in) thick stainless steel plate with a $2.5 \mathrm{~cm}$ ( 1 in) outer closure plate, separated by $46 \mathrm{~mm}$ (1.8 in) of lead gamma shielding. Twenty-four explosively bonded copper/stainless steel fins are located within the radial neutron shield to enhance heat rejection. Six trunnions can be attached to the cask for lifting and rotating the cask.

The fuel basket is a right circular cylinder configuration with 26 aluminum fuel tubes that are separated and supported by an aluminum and stainless steel grid of spacers and tie bars. Sheets of borated neutron poison plates form the outer walls of the fuel tubes to provide criticality control.

\subsubsection{Operations}

The major operating systems are those required for handling and transferring the fuel from the SFP to the ISFSI for storage, and likewise for removing the fuel from the ISFSI. The cask is loaded underwater in the SFP and the closure lid is bolted on the cask. The cask is then lifted to the surface 
of the pool and drained. Next, it is vacuum dried, decontaminated, pressurized with helium, and a pressure-monitoring device is installed in the double-seal interspace. The neutron shield cap is installed and the cask is then transferred to the ISFSI site and is set on the concrete pad. The pressuremonitoring system is externally connected and will notify plant operators of a loss of seal integrity. Unloading procedures are similar to the loading procedures (in reverse).

The cask is a totally passive system with natural cooling sufficient to maintain safe fuel cladding temperatures. The cask wall provides adequate shielding, and no radioactive products are released under any credible conditions. Normal radiation survey monitoring is also performed.

\subsubsection{Reference Documents}

Nuclear Assurance Corporation, "Topical Safety Analysis Report for the NAC Storage/Transport Cask for Use at an Independent Spent Fuel Storage Installation," Rev. 1, December 1986. (Docket 72 1002)

U.S. Nuclear Regulatory Commission, Office of Nuclear Material Safety and Safeguards, "Safety Evaluation Report for the Topical Safety Analysis Report for the NAC S/T Cask," March 1988. (Docket 72-1002) 


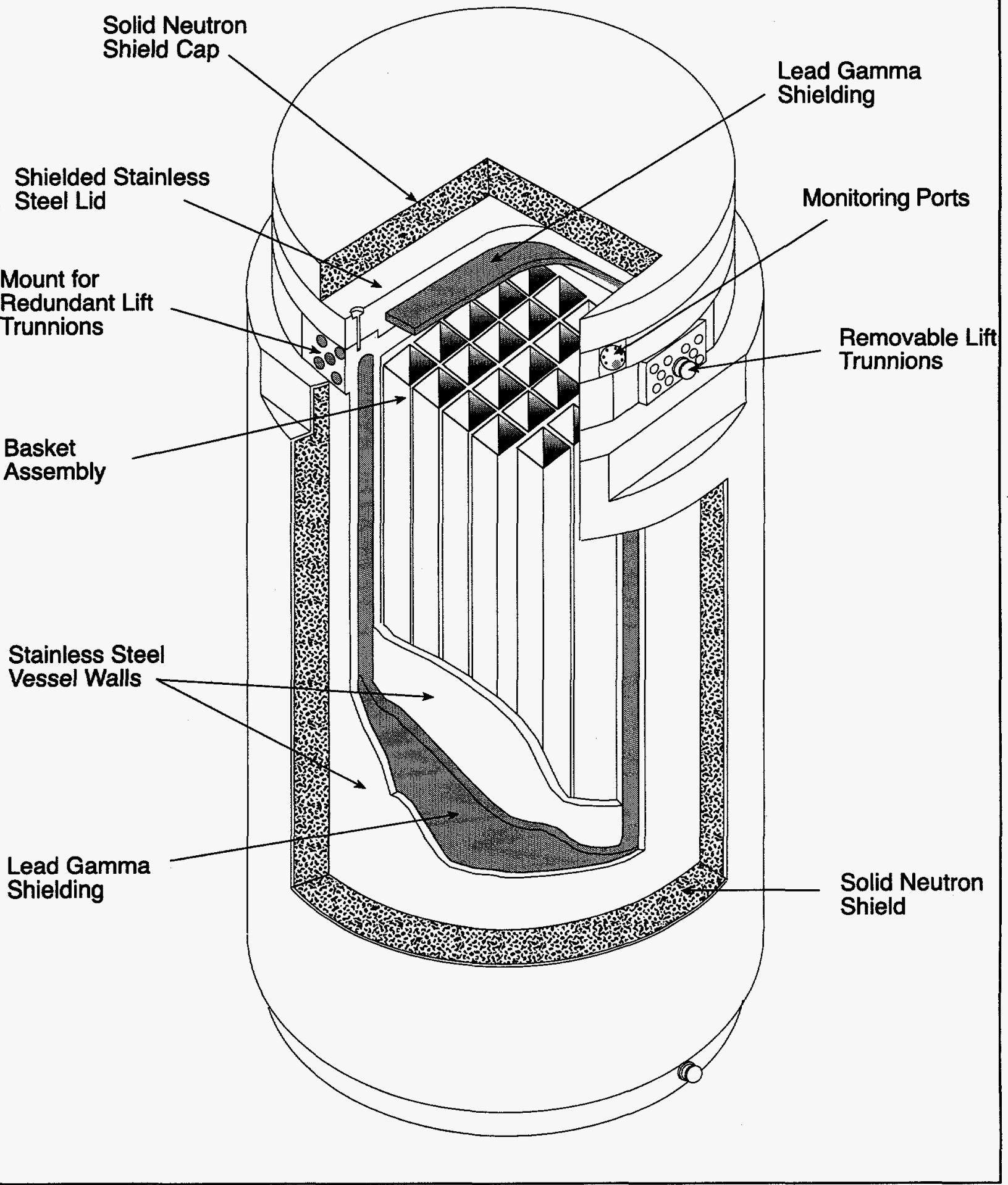

Figure 3.5-1 Diagram of the NAC-S/T General Cask Design 


\subsection{NAC-I28 S/T}

The NAC-I28 S/T cask, made by the Nuclear Assurance Corporation, is a metal DCSS designed to vertically store 28 intact PWR SFAs. It evolves from the NAC-S/T design (see Section 3.5). The cask is approximately $4.6 \mathrm{~m}(15.1 \mathrm{ft})$ high and $2.4 \mathrm{~m}(7.9 \mathrm{ft})$ in diameter. It weighs approximately 98 tonnes (108 ton) when loaded with SFAs, contained water, and lifting yoke. The NAC-I28 S/T is currently used at the Surry ISFSI. A diagram of the general cask design is shown in Figure 3.5-1.

\subsubsection{Cask Body}

The cask body consists of a cylindrical, multi-wall construction of stainless steel components. It has an approximately $4 \mathrm{~cm}$ (1.5 in.) thick inner shell and a $6.7 \mathrm{~cm}$ (2.6 in.) thick outer shell of stainless steel separated by approximately $8 \mathrm{~cm}(3 \mathrm{in}$.) of poured-in-place chemical lead. The inner and outer shell are connected to each other on both ends by austenitic stainless steel rings and plates. The upper end of the cask is sealed by a stainless steel bolted closure lid which is $16.5 \mathrm{~cm}$ (6.5 in.) thick in the edge flange region and has a $2.5 \mathrm{~cm}$ (1 in.) inner closure plate and a $14 . \mathrm{cm}(5.5 \mathrm{in}$.) thick outer closure plate. The closure plates are separated by approximately $5 \mathrm{~cm} \mathrm{(2} \mathrm{in.)} \mathrm{of} \mathrm{lead.} \mathrm{The} \mathrm{closure} \mathrm{lid}$ uses a double-barrier seal system with two metallic O-ring seals. A $7.6 \mathrm{~cm}$ (3 in.) thick neutron shield cap encased in stainless steel is placed on top of the cask and may be welded to the cask body. Gamma shielding is provided by the lead wall, and neutron shielding is provided by an $17.8 \mathrm{~cm}(7 \mathrm{in}$.) thick layer of a poured-in-place solid borated synthetic polymer which surrounds the outer shell along the cavity region, and is enclosed by a $6.4 \mathrm{~mm}(0.25 \mathrm{in})$ thick stainless steel shield shell with end plates. The bottom of the cask is sealed by a $15.2 \mathrm{~cm}(6 \mathrm{in}$.) thick stainless steel plate with a $2.5 \mathrm{~cm}(1$ in.) thick outer closure plate separated by $4.6 \mathrm{~cm}$ (1.8 in.) of lead gamma shielding. Twenty-four explosively bonded copper/stainless steel fins are located within the radial neutron shield to enhance heat rejection. Six trunnions can be attached to the cask body for lifting and rotating the cask.

The fuel basket is a right circular cylinder configuration with 28 aluminum fuel tubes that are separated and supported by an aluminum and stainless steel grid of spacers and tie bars, with borated neutron poison material (for criticality control) in the basket assembly.

\subsubsection{Operations}

The major operating systems are those required for handling and transferring the fuel from the SFP to the ISFSI for storage, and likewise for removing the fuel from the ISFSI. The cask is loaded underwater in the SFP and the closure lid is bolted on the cask. The cask is then lifted to the surface of the pool and drained. Next, it is vacuum dried, decontaminated, pressurized with helium, and a pressure-monitoring device is installed in the double seal interspace. The neutron shield cap is installed and the cask is then transferred to the ISFSI site and is set on the concrete pad. The pressure- 
monitoring system is externally connected and will notify plant operators of a loss of seal integrity. Unloading procedures are similar to the loading procedures (in reverse).

The cask is a totally passive system with natural cooling sufficient to maintain safe fuel cladding temperatures. The cask wall provides adequate shielding, and no radioactive products are released under any credible conditions. Normal radiation survey monitoring of the ISFSI is also performed.

\subsubsection{Reference Documents}

Nuclear Assurance Corporation, "Topical Report for the NAC S/T Cask Containing 28 Intact Fuel Assemblies for Use at an Independent Spent Fuel Storage Facility," November 1988. (Docket 721020)

U.S. Nuclear Regulatory Commission, Office of Nuclear Material Safety and Safeguards, "Safety Evaluation Report Related to the TSAR for the NAC-I28 Storage/Transport Cask Submitted by Nuclear Assurance Corporation," February 1990. (Docket 72-1020)

Virginia Electric \& Power Company, "Safety Analysis Report for Surry Power Station Dry Cask Independent Spent Fuel Storage Installation," Rev. 7, 1994. (Docket 72-2) 
3.7

NAC-C28 S/T: Certificate of Compliance \# 1003

The NAC-C28 S/T storage cask, made by Nuclear Assurance Corporation, is a metal DCSS designed to vertically store 28 consolidated fuel assemblies. It is identical to the NAC-I28 S/T but has a certificate of compliance to store consolidated fuel. A diagram of the general cask design is shown in Figure 3.5-1. Refer to Section 3.6 for further description. The NAC-C28 S/T currently is not in use at any existing ISFSIs.

\subsubsection{Reference Documents}

Nuclear Assurance Corporation, "Topical Safety Analysis Report for the NAC Storage/Transport Cask Containing Consolidated Fuel for Use at an Independent Spent Fuel Storage Installation," Rev. 2, April 1987. (Docket 72-1003)

U.S. Nuclear Regulatory Commission, Office of Nuclear Materials Safety and Safeguards, "Safety Evaluation Related to the Topical Safety Analysis Report for the NAC Storable/Transport Cask, Rev. 2", March 1988. (Docket 72-1033) 


\subsection{NAC-STC}

The NAC-STC storage cask, made by Nuclear Assurance Corporation, is a metal DCSS designed to vertically store 26 intact fuel assemblies. It evolves from the NAC-S/T (see Section 3.5), and has been designed to be licensed as a dual-purpose cask for both storage and transport of spent fuel. The cask is approximately $4.6 \mathrm{~m}(15.1 \mathrm{ft})$ high and $2.4 \mathrm{~m}(7.9 \mathrm{ft})$ in diameter. It weighs approximately 107 tonnes (117 tons) when loaded with SFAs, contained water, and lifting yoke. The NAC-STC currently is not in use at any existing ISFSIs. A diagram of the general cask design is shown in Figure $3.5-1$.

\subsubsection{Cask Body}

The cask body consists of a cylindrical, multi-wall construction of stainless steel components. It has an approximately $3.8 \mathrm{~cm}$ (1.5 in.) thick inner shell and a $6.7 \mathrm{~cm}(2.7 \mathrm{in}$.) thick outer shell of stainless steel separated by $9.4 \mathrm{~cm}$ ( $3.7 \mathrm{in}$.) of poured-in-place chemical lead. The inner and outer shell are connected to each other on both ends by welded stainless steel forgings. The upper end of the cask is sealed by a stainless steel inner lid which is approximately $23 \mathrm{~cm}(9 \mathrm{in}$.) thick, with a $5 \mathrm{~cm}(2 \mathrm{in}$.) thick BISCO neutron shielding material in the center and a $2.5 \mathrm{~cm}$ (1 in.) thick stainless steel coverplate. The upper end is further sealed by a $13.3 \mathrm{~cm}$ ( $5.25 \mathrm{in}$.) thick outer lid bolted to the top forging. Gamma shielding is provided by the lead wall, and neutron shielding is provided by a $14 \mathrm{~cm}$ (5.5 in.) thick layer of a poured-in-place solid borated synthetic polymer which surrounds the outer shell along the cavity region, and is enclosed by $6.4 \mathrm{~mm}(0.25 \mathrm{in}$.) thick stainless steel shield shell and end plates that are welded to the outer shell. The bottom of the cask is sealed by two stainless steel forgings and a stainless steel plate. Twenty-four explosively bonded copper/stainless steel fins are located within the radial neutron shield to enhance heat rejection. Six trunnions can be attached to the cask body for lifting and rotating the cask.

The fuel basket is a right circular cylinder configuration with 26 aluminum fuel tubes that are separated and supported by an aluminum and stainless steel grid of spacers and tie bars. Sheets of borated neutron poisons plates form the outer walls of the fuel tubes to provide criticality control.

\subsubsection{Operations}

The major operating systems are those required for handling and transferring the fuel from the SFP to the ISFSI for storage, and likewise for removing the fuel from the ISFSI. The cask is loaded underwater in the SFP and the closure lid is bolted on the cask. The cask is then lifted to the surface of the pool and drained. Next, it is vacuum dried, decontaminated, pressurized with helium, and a pressure-monitoring device is installed in the double seal interspace. The neutron shield cap is installed and the cask is transferred to the ISFSI site where it is set in place on the concrete pad. The 
pressure-monitoring system is externally connected and will notify plant operators of a loss of seal integrity. Unloading procedures are similar to the loading procedures (in reverse).

The cask is totally passive system with natural cooling sufficient to maintain safe fuel cladding temperatures. The cask wall provides adequate shielding, and no radioactive products are released under any credible conditions.

\subsubsection{Reference Documents}

Nuclear Assurance Corporation, "Topical Safety Analysis Report for the NAC Storable Transport Cask for Use at an Independent Spent Fuel Storage Installation," Rev. 3A, September 1995. (Docket 72-1013)

U.S. Nuclear Regulatory Commission, Office of Nuclear Material Safety and Safeguards, "Spent Fuel Storage Safety Evaluation Report Related to the Topical Safety Analysis Report for the NAC Storable Transport Cask (NAC-STC)," July 1995. (Docket 72-1013) 


\subsection{NUHOMS-7P}

The NUHOMS-7P system, made by VECTRA Technologies, Inc., is a concrete module DCSS designed to horizontally store seven PWR SFAs. The principal components of the NUHOMS-7P system are a stainless steel dry shielded canister (DSC) with an internal fuel basket, a concrete horizontal storage module (HSM) that protects the DSC and provides radiological shielding (overpack), a compatible transfer cask (TC) used to transfer the DSC from the spent fuel pool to the HSM, and a hydraulic ram system (HRS) used to insert the DSC into the HSM and TC. The NUHOMS-7P is currently used at the H.B. Robinson ISFSI.

\subsubsection{Dry Shielded Canister (DSC)}

The DSC is designed to provide primary containment for seven SFAs, and is shown in Figure 3.9-1.

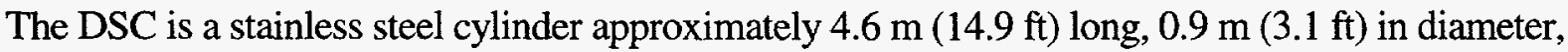
and $1.3 \mathrm{~cm}(0.5 \mathrm{in}$.) thick. Stainless steel end plates and steel end plugs filled with lead are welded to the both top and bottom of the DSC with double seal welds. The canister contains a basket assembly made of seven guide sleeves consisting of stainless steel boral cladding (for criticality control) that are held by spacer disks. The basket geometry and guide sleeves provide criticality control. The lower end of the DSC is coated with a lubricant to reduce friction when it is inserted and removed from the TC and HSM.

\subsubsection{Horizontal Storage Module (HSM)}

An HSM is shown in Figure 3.9-2. The HSM is constructed of reinforced concrete, structural steel, and stainless steel. The HSM may be constructed as a single unit or as an array of modules (e.g., 2X20). A photograph of an HSM array is shown in Figure 3.9-3. A NUHOMS-7P HSM is approximately $5.9 \mathrm{~m}(19 \mathrm{ft})$ long, $3.7 \mathrm{~m}(12 \mathrm{ft})$ high, and $1.7 \mathrm{~m}(5.6 \mathrm{ft})$ wide. The concrete walls and roof are $16.5 \mathrm{~cm}(3.5 \mathrm{ft})$ in thickness, and interior walls are $61 \mathrm{~cm}(2 \mathrm{ft})$ in thickness. Gamma and neutron shielding are provided by the HSM structure. A steel support rail structure anchored inside the HSM by the interior walls supports the DSC and extends to the access opening. Stoppers on the rails prevent horizontal movement of the DSC during a seismic event. A vertically sliding plate, consisting of thick steel and a neutron-absorbing material, covers the entrance to the HSM and is tack welded closed when the DSC is in place. Each HSM has two shielded air inlets on the front and two shielded air outlets on the roof.

\subsubsection{Transfer Cask (TC)}

The TC is used to transfer the DSC from the SFP to the HSM. A TC is approximately $4.6 \mathrm{~m}(15 \mathrm{ft})$ long with an inner diameter of $95 \mathrm{~cm}$ (37.5 in). An approved transfer cask that is used with the 7P is a modified General Electric IF-300 shipping cask, with an extension on the cask head. A compatible TC consists of three concentric cylinders with shielding material in between, connected by top and integral steel bottom end plates with a solid neutron shield. The bottom end plate may have a removable HRS access port plug. The TC wall consists of an inner stainless steel liner, a poured-lead 
shield, a structural carbon steel shell, a neutron shield, and an outer carbon steel shell. It is hoisted by the trunnions located on its sides, and mates (via transfer trailer) with the access opening of the HSM for transfer of the DSC.

\subsubsection{Hydraulic Ram System (HRS)}

The HRS provides the motive force for transferring the DSC between the HSM and TC. The HRS consists of a single-stage hydraulic cylinder with a grapple assembly and is powered by a hydraulic power unit. The hydraulic cylinder is supported by support frame and is designed to apply pushing or pulling forces of $90 \mathrm{kN}$ (20 kip) during normal operation.

\subsubsection{Operations}

The major operating systems are those required for handling and transferring the fuel from the SFP to the ISFSI for storage, and likewise for removing the fuel from the ISFSI. Fuel handling procedures are shown in Figure 3.9-4. First, the DSC is placed in the TC, and is lowered into the SFP. After the fuel is loaded into the DSC, the DSC shield plug is placed on the DSC and the TC is raised out of the SFP. The DSC and TC are then decontaminated and drained. The DSC is vacuum dried, pressurized with helium, and sealed. The TC lid is then bolted to the cask, and the TC is lowered horizontally onto a transfer trailer. The TC is transferred to the ISFSI and the cask is mated (top side) to the HSM. The HRS arm is inserted through the TC rear access port and pushes the DSC into the HSM. The TC is then removed and the access steel cover plate is tack welded sealed to the HSM. Unloading procedures are similar to the loading procedures (in reverse).

The decay heat is removed passively by natural draft convection. Air enters the lower part of the HSM, rises around the DSC, and exits through the top shielded slab. The only required maintenance is the periodic inspection of the air inlet and outlet screens to ensure that they have not been blocked by debris.

\subsubsection{Reference Documents}

NUTECH Engineers, Inc., "Topical Report NUH-001 for the NUTECH Horizontal Modular Storage System for Irradiated Nuclear Fuel, NUHOMS-7P," Rev. 1A., June 1986. (Docket 72-1022)

U.S. Nuclear Regulatory Commission, Office of Nuclear Material Safety and Safeguards, "Safety Evaluation Report for NUTECH Horizontal Modular Storage System for Irradiated Nuclear Fuel Topical Report (NUHOMS-7)," March 28, 1986. (Docket 72-1022)

General Electric Co., "IF-300 Consolidated Safety Analysis Report," NEDO-10048-2, Nuclear Fuel and Special Products Division, March 1983. 


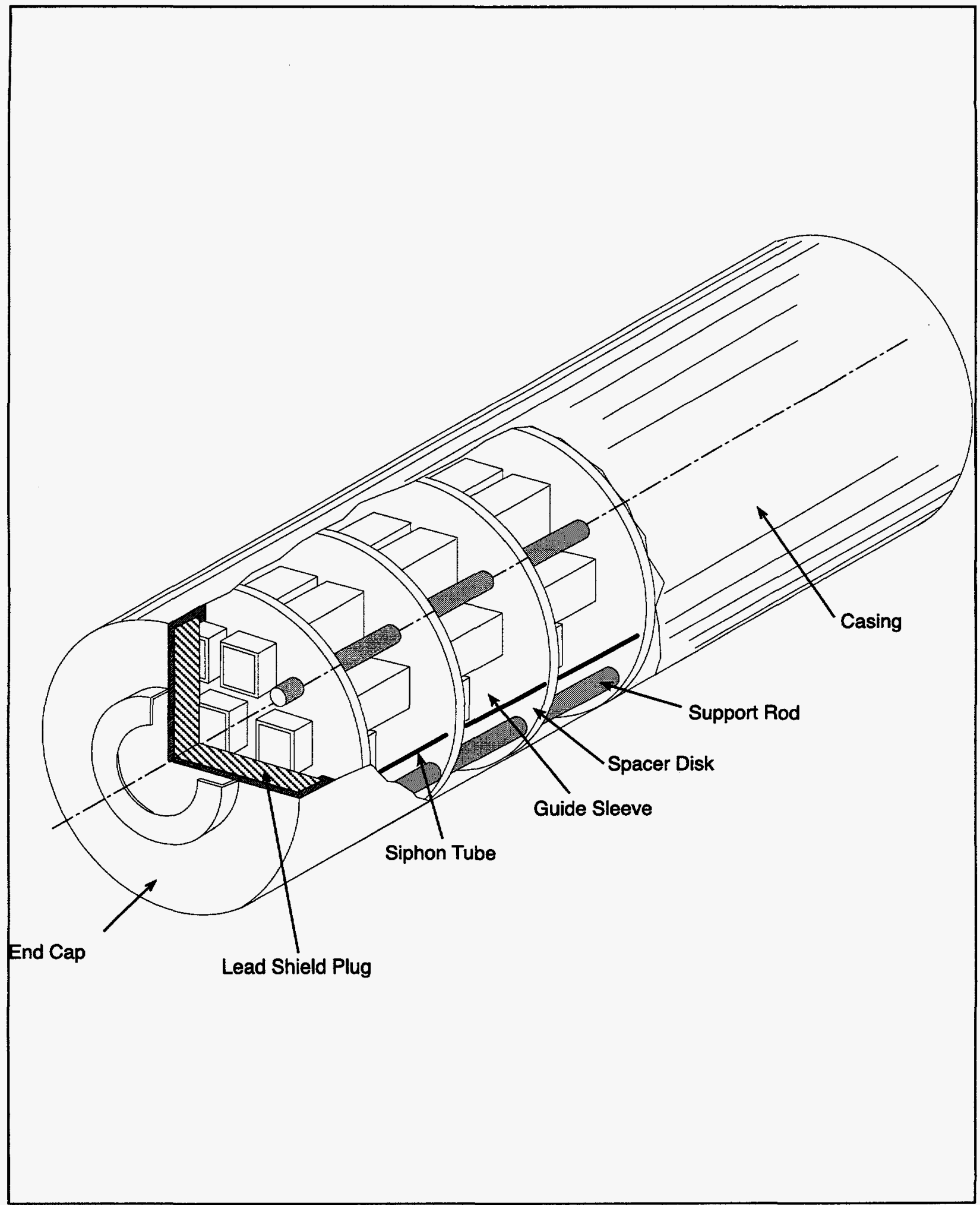

Figure 3.9-1 Diagram of the NUHOMS-7P DSC 


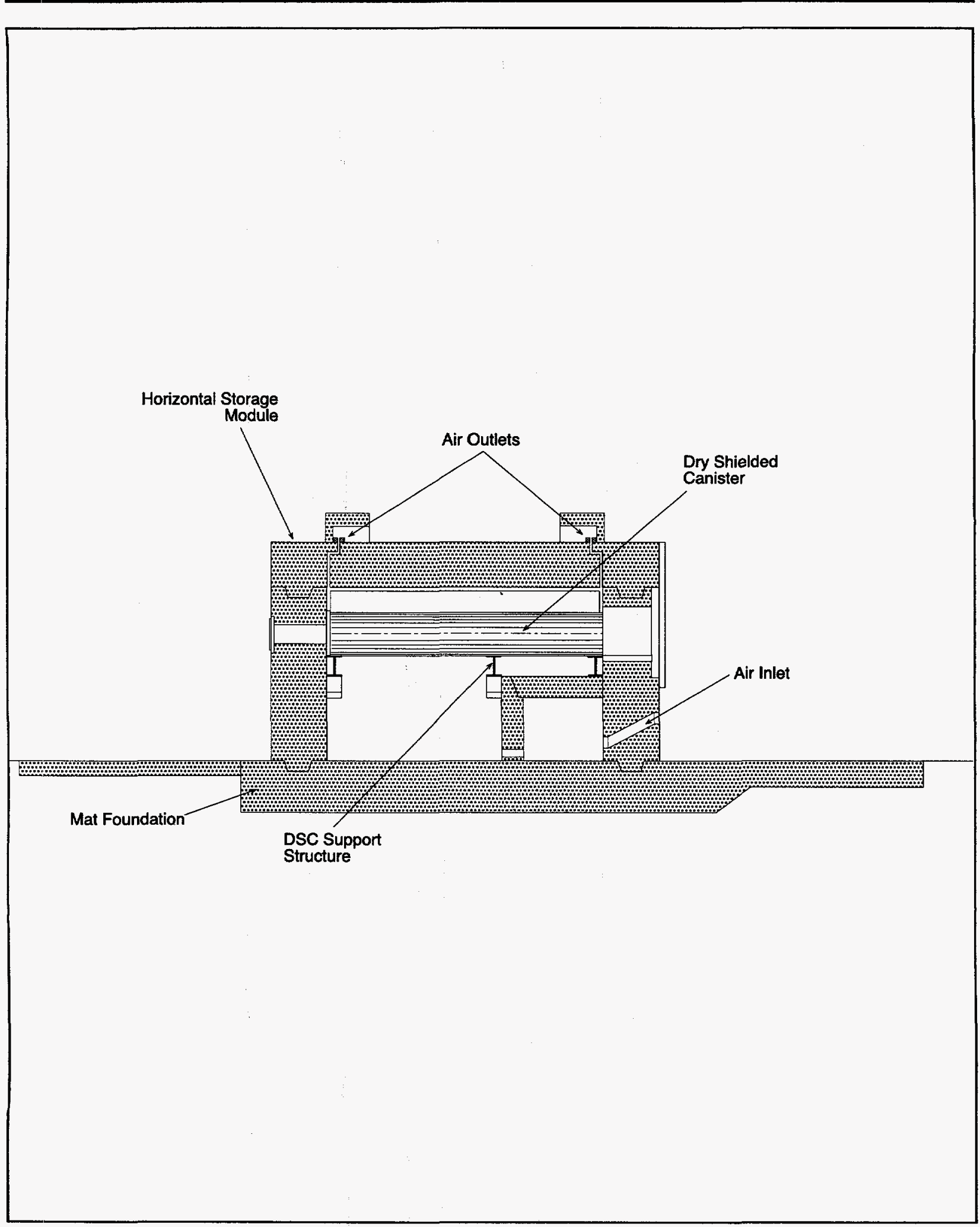

Figure 3.9-2 Diagram of the NUHOMS-7P HSM 


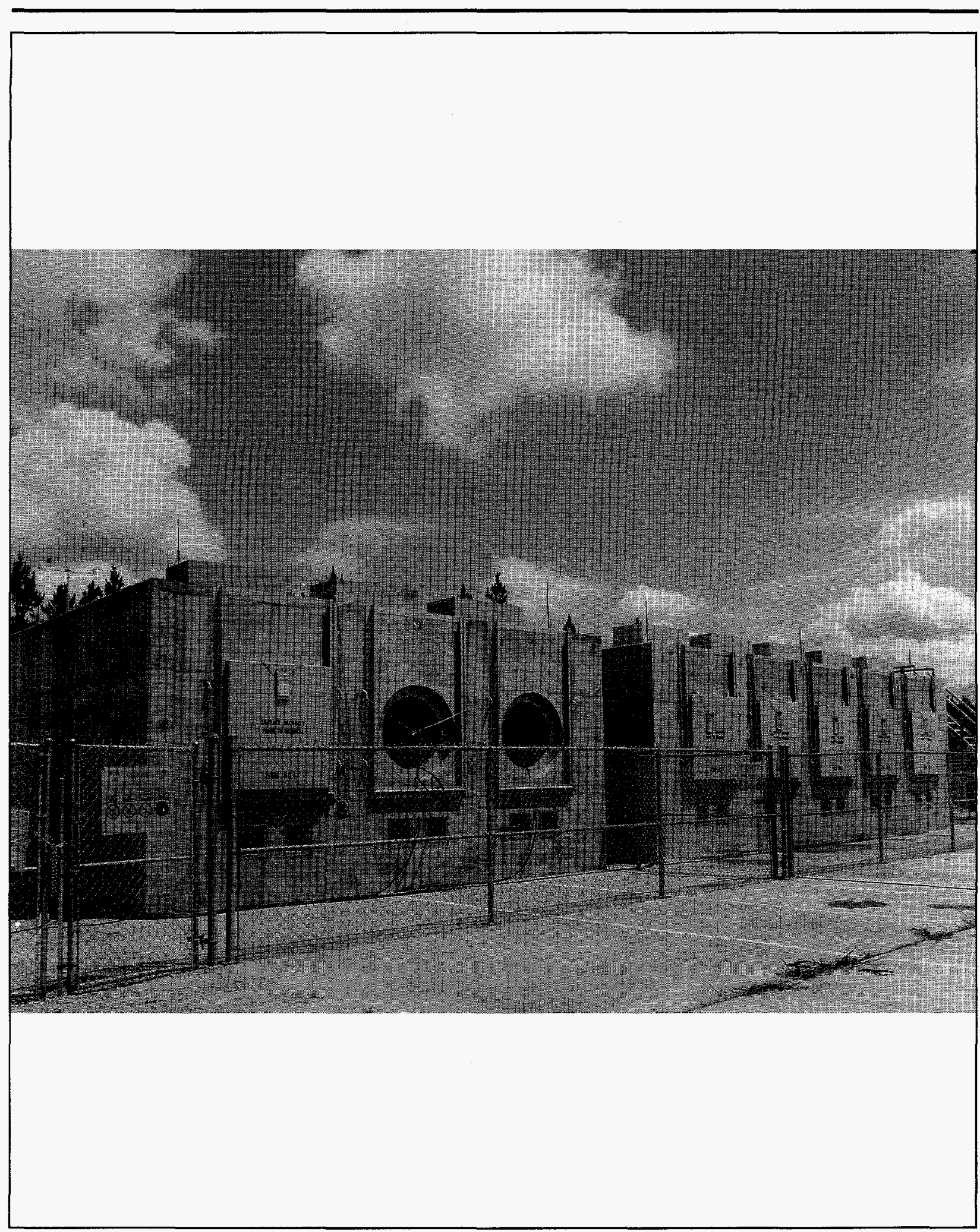

Figure 3.9-3 Photograph of an HMS array 


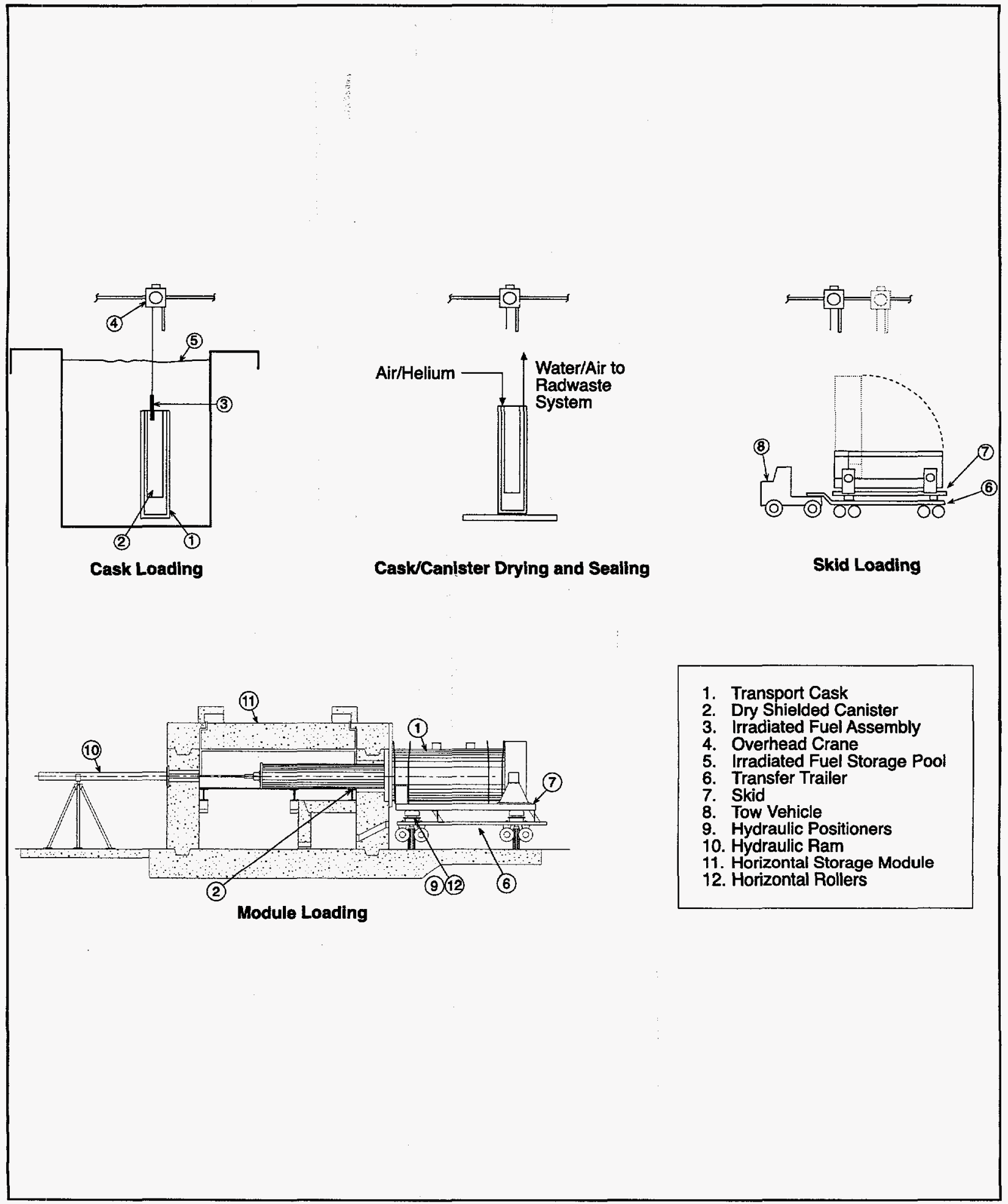

Figure 3.9-4 NUHOMS 7-P Fuel Handling Procedures 


\subsection{NUHOMS-24P}

The NUHOMS-24P system, made by VECTRA Technologies, Inc., is a concrete module DCSS designed to horizontally store 24 PWR SFAs. The NUHOMS-24P design evolves from the NUHOMS-7P, in which the fuel basket capacity and overall physical size are increased. The principal components of the NUHOMS-24P system are a stainless steel dry shielded canister (DSC) with an internal fuel basket, a concrete horizontal storage module (HSM) that protects the DSC and provides radiological shielding (overpack), a transfer cask (TC) used to transfer the DSC from the spent fuel pool to the HSM, and a hydraulic ram system (HRS) used to insert the DSC into the HSM and TC. The NUHOMS-24P is currently used at the Oconee and the Calvert Cliffs ISFSIs.

\subsubsection{Dry Shielded Canister (DSC)}

The DSC is designed to provide primary containment for 24 SFAs, and is shown in Figure 3.10-1. The DSC is a stainless steel cylinder approximately $4.7 \mathrm{~m}(15.5 \mathrm{ft})$ long, $1.7 \mathrm{~m}(5.6 \mathrm{ft})$ in outside, and $16 \mathrm{~mm}(0.63 \mathrm{in}$.) thick. Stainless steel end plates and steel end plugs filled with lead are welded to the both top and bottom of the DSC with redundant seal welds. The canister contains a basket assembly made of 24 stainless steel guide sleeves. The basket geometry and guide sleeves provide criticality control. The lower end of the DSC is coated with a lubricant to reduce friction when it is inserted and removed from the TC and HSM.

\subsubsection{Horizontal Storage Module (HSM)}

The HSM is shown in Figure 3.10-2. The HSM is constructed of reinforced concrete, structural steel, and stainless steel. The HSM may be constructed as a single unit or as an array of modules (e.g., 2X20). A photograph of an HSM array is shown in Figure 3.9-3. A NUHOMS-24P HSM is approximately $6.1 \mathrm{~m}(20 \mathrm{ft})$ long, $4.6 \mathrm{~m}(15 \mathrm{ft})$ high, and $2.7 \mathrm{~m}(8.7 \mathrm{ft})$ wide. The concrete walls and

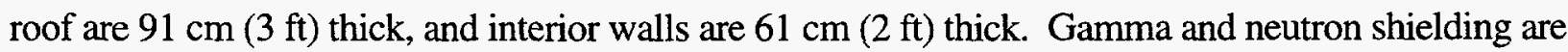
provided by the HSM structure. A steel support rail structure anchored inside the HSM by the interior walls supports the DSC and extends to the access opening. Stoppers on the rails prevent horizontal movement of the DSC during a seismic event. A vertically sliding plate, consisting of thick steel and a neutron-absorbing material, covers the entrance to the HSM and is tack welded closed when the DSC is in place. Each HSM has two shielded air inlets on the front and two shielded air outlets on the roof.

\subsubsection{Transfer Cask (TC)}

The TC is used to transfer the DSC from the SFP to the HSM. The TC, shown in Figure 3.10-3, is approximately $4.75 \mathrm{~m}$ (15.6 ft) long with an inner diameter of $1.7 \mathrm{~m}(5.7 \mathrm{ft})$. It consists of three concentric cylinders with shielding material in between, connected by top and integral steel bottom end plates with a solid neutron shield. The bottom end plate has a removable HRS access port plug. 
The TC wall consist of an inner stainless steel liner, a poured-lead shield, a structural carbon steel shell, a solid BISCO-N3 neutron shield, and an outer carbon steel shell. It is hoisted by the trunnions located on its sides, and mates (via transfer trailer) with the access opening of the HSM for transfer of the DSC.

\subsubsection{Hydraulic Ram System (HRS)}

The HRS provides the motive force for transferring the DSC between the HSM and TC. The HRS consists of a single-stage hydraulic cylinder with a grapple assembly and is powered by a hydraulic power unit. The hydraulic cylinder is supported by support frame and is designed to apply pushing or pulling forces of $90 \mathrm{kN}$ (20 kip) during normal operation.

\subsubsection{Operations}

The major operating systems are those required for handling and transferring the fuel from the SFP to the ISFSI for storage, and likewise for removing the fuel from the ISFSI. First, the DSC is placed in the TC, and is lowered into the SFP. After the fuel is loaded into the DSC, the DSC shield plug is placed on the DSC and the TC is raised out of the SFP. The DSC and TC are then decontaminated and drained. The DSC is vacuum dried, pressurized with helium, and sealed. The TC lid is then bolted to the cask, and the TC is lowered horizontally onto a transfer trailer. The TC is transferred to the ISFSI and the cask is mated (top side) to the HSM, as shown in Figure 3.10-4. The HRS arm is inserted through the TC rear access port and pushes the DSC into the HSM. The TC is then removed and the access steel cover plate is tack welded sealed to the HSM. Unloading procedures are similar to the loading procedures (in reverse).

The decay heat is passively removed by natural draft convection. Air enters the lower part of the HSM, rises around the DSC, and exits through the top shielded slab. The only required maintenance is the periodic inspection of the air inlet and outlet screens to ensure that they have not been blocked by debris.

\subsubsection{Reference Documents}

Baltimore Gas and Electric Company (BG\&E), "Calvert Cliffs Independent Spent Fuel Storage Installation Safety Analysis Report," 1989. (Docket Number 72-8)

Duke Power Company, "Independent Spent Fuel Storage Facility, Oconee Nuclear Site Final Safety Analysis report," December 1995. (Docket Number 72-4)

NUTECH Engineers, Inc., "Topical Report for the NUTECH Horizontal Modular Storage System for Irradiated Nuclear Fuel," NUH-001, Rev.1, November 1985. 
NUTECH Engineers Inc., "Topical Report for the NUTECH Horizontal Modular Storage System for Irradiated Nuclear Fuel, NUHOMS-24P," NUH-002, Rev. 1A, July 1989.

U.S. Nuclear Regulatory Commission, Office of Nuclear Material Safety and Safeguards, "Safety Evaluation Report for NUTECH Horizontal Modular Storage System for Irradiated Nuclear Fuel Topical Report (NUHOMS-7)," March 28, 1986.

U.S. Nuclear Regulatory Commission, Office of Nuclear Material Safety and Safeguards, "Safety Evaluation Report Related to the TR for the NUTECH Horizontal Modular Storage System for Irradiated Nuclear Fuel Submitted by NUTECH Engineers, Inc., NUH-002, Rev. 1A," April 1989. 


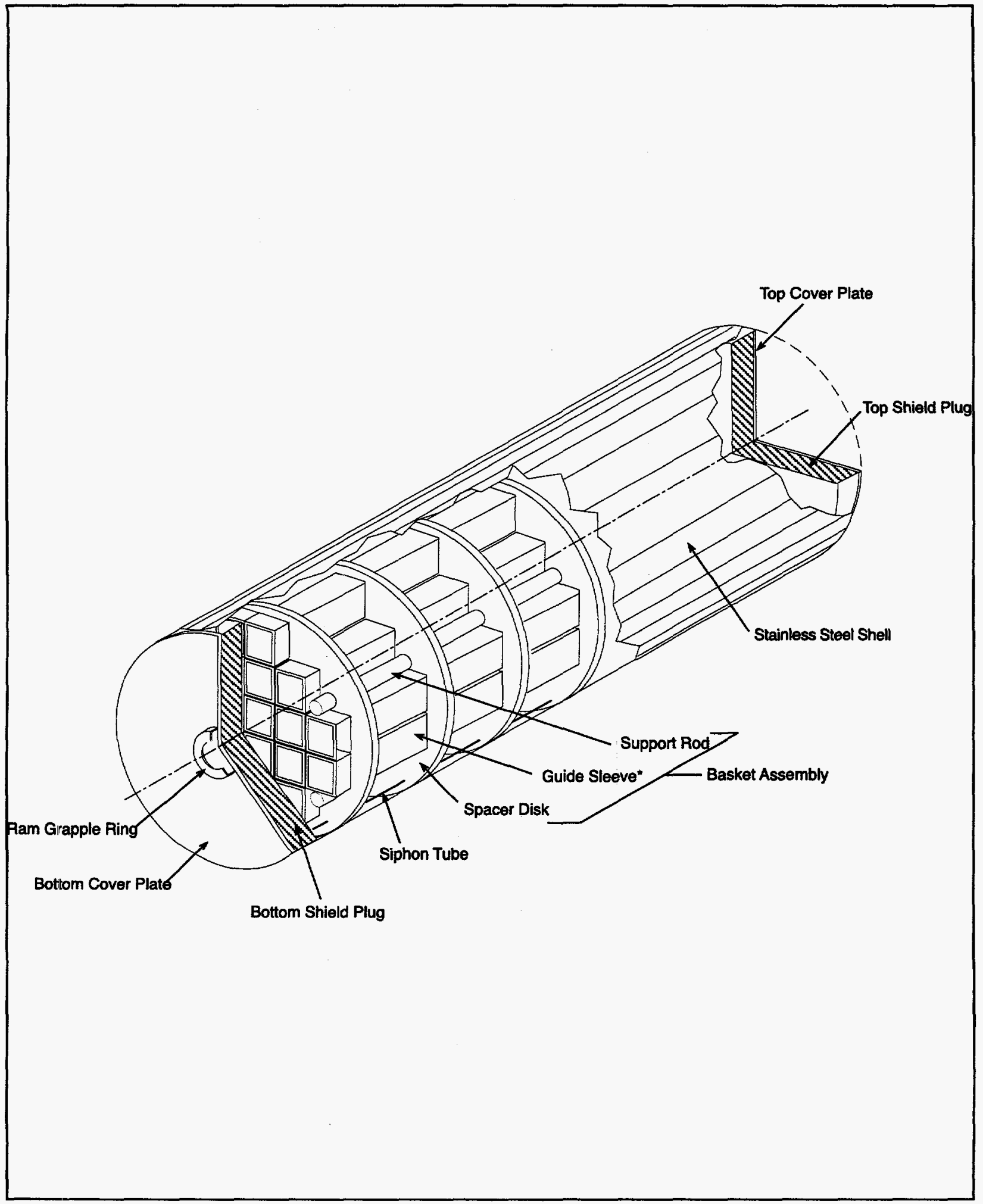

Figure 3.10-1 Diagram of the NUHOMS-24P DSC 


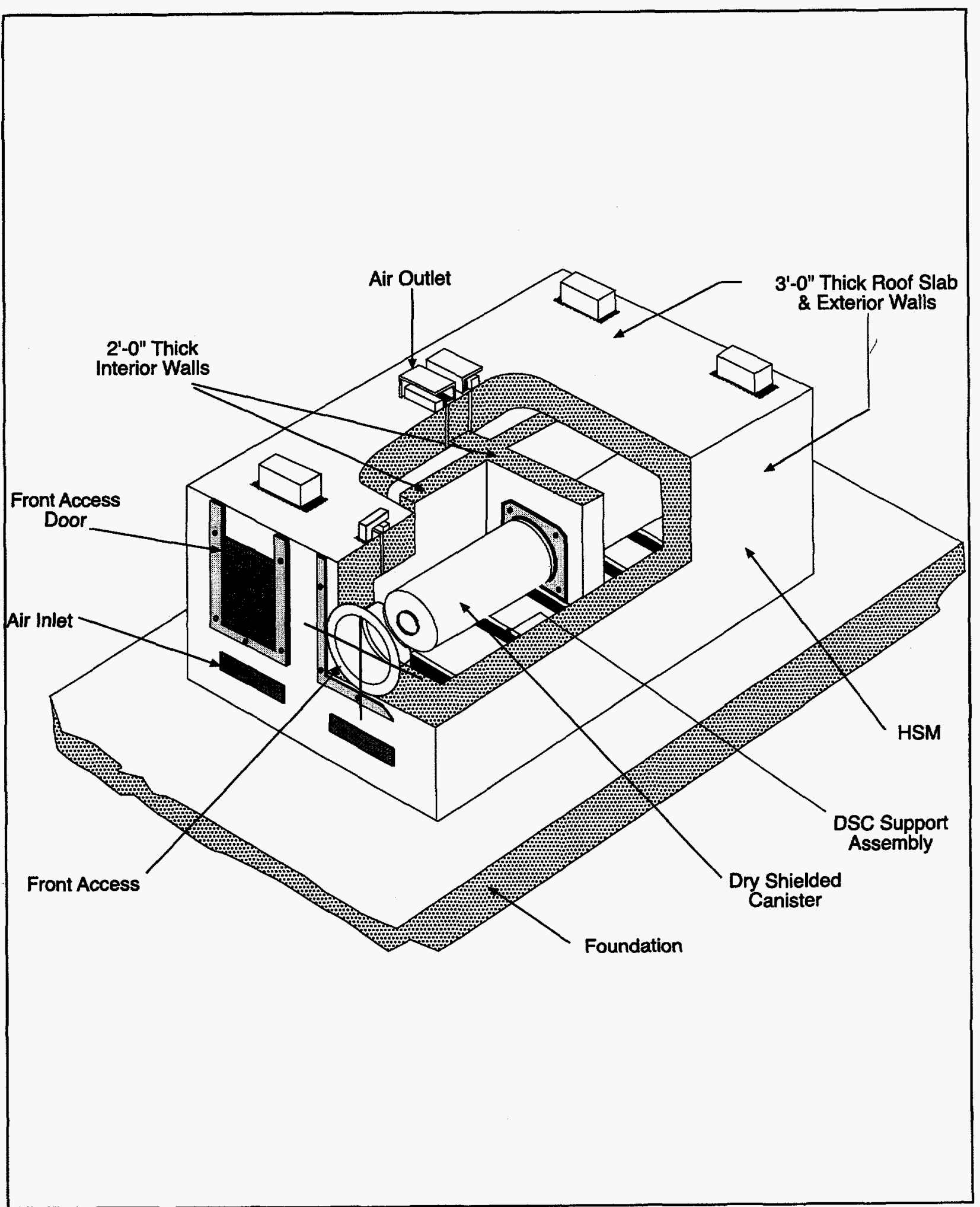

Figure 3.10-2 Diagram of the NUHOMS-24 HSM 


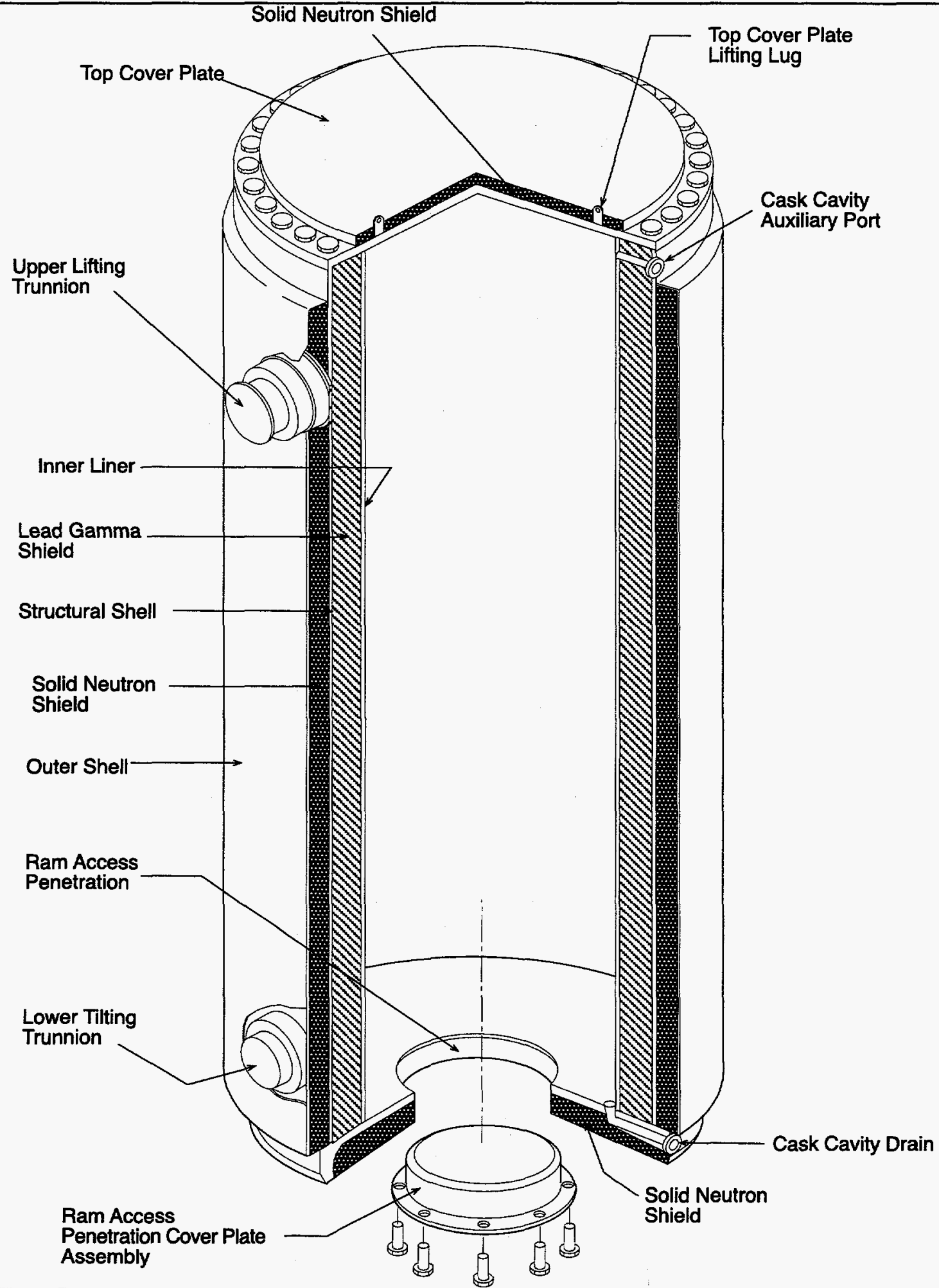

Figure 3.10-3 Diagram of a NUHOMS On-Site Transfer Cask 


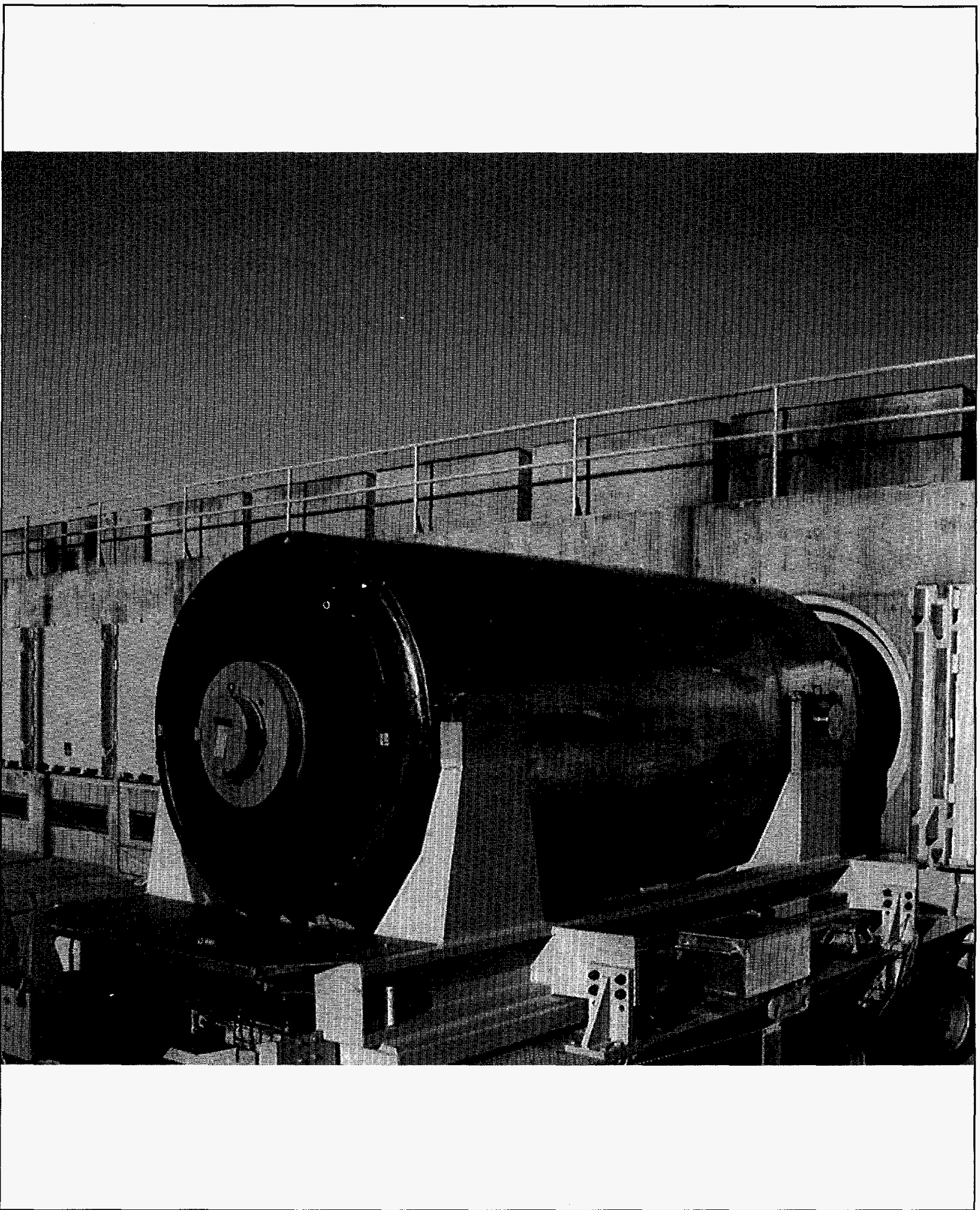

Figure 3.10-4 Photograph of a NUHOMS TC Being Mated with an HSM 


\subsection{Standardized NUHOMS-24P/52B: Certificate of Compliance \#1004}

The standardized NUHOMS-24P/52B, made by VECTRA Technologies, Inc., is a concrete DCSS designed to horizontally store either 24 PWR SFAs or 52 BWR SFAs. The NUHOMS design evolves from and is similar to the NUHOMS-24P (see Section 3.10) which is used only for sitespecific licenses. The fuel basket, however, can be manufactured to store either PWR or BWR fuel assemblies. The principal components of the standardized NUHOMS are a stainless steel dry shielded canister (DSC) with an internal fuel basket, a concrete horizontal storage module (HSM) that protects the DSC and provides radiological shielding (overpack), a transfer cask (TC) used to transfer the DSC from the spent fuel pool to the HSM, and a hydraulic ram system (HRS) used to insert the DSC into the HSM and TC. The standardized NUHOMS is currently used at Davis-Besse, and is planned for use at Oyster Creek (52B) and FitzPatrick (24P).

\subsubsection{Dry Shielded Canister (DSC)}

The DSC is designed to provide primary containment for 24 PWR SFAs or 52 BWR SFAs, and is shown in Figure 3.11-1. The DSC is a stainless steel cylinder approximately $4.7 \mathrm{~m}(15.5 \mathrm{ft})$ long, 1.7 $\mathrm{m}(5.6 \mathrm{ft})$ in diameter, and $16 \mathrm{~mm}(0.63 \mathrm{in}$.) thick. Stainless steel end plates and steel end plugs filled with lead are welded to the both top and bottom of the DSC with redundant seal welds. The canister contains a basket assembly made of 24 or 52 guide sleeves consisting of stainless steel. The basket geometry and guide sleeves provide criticality control. The basket assembly for BWR SFA loading has additional neutron-absorbing plates. The lower end of the DSC is coated with a lubricant to reduce friction when it is inserted and removed from the TC and HSM.

\subsubsection{Horizontal Storage Module (HSM)}

An HSM is shown in Figure 3.11-2. The HSM is constructed of reinforced concrete, structural steel, and stainless steel. The HSM may be constructed as a single unit or as an array of modules (e.g., 2X20). A photograph of an HSM array is shown in Figure 3.9-3. A Standardized NUHOMS HSM is approximately $6.1 \mathrm{~m}(20 \mathrm{ft})$ long, $4.6 \mathrm{~m}(15 \mathrm{ft})$ high, and $2.7 \mathrm{~m}(8.7 \mathrm{ft})$ wide. The concrete walls and

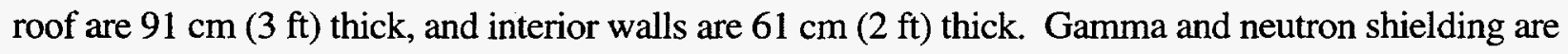
provided by the HSM structure. A steel support rail structure anchored inside the HSM by the interior walls supports the DSC and extends to the access opening. Stoppers on the rails prevent horizontal movement of the DSC during a seismic event. A vertically sliding plate, consisting of thick steel and a neutron-absorbing material, covers the entrance to the HSM and is tack welded closed once the DSC is in place. Each HSM has two shielded air inlets on the front and two shielded air outlets on the roof. 


\subsubsection{Transfer Cask (TC)}

The TC is used to transfer the DSC from the SFP to the HSM. The TC, shown in Figure 3.10-3, is approximately $4.75 \mathrm{~m}(15.6 \mathrm{ft})$ long with an inner diameter of $1.7 \mathrm{~m}(5.7 \mathrm{ft})$. The length can be extended to accommodate BWR SFAs. It consists of three concentric cylinders with shielding material in between, connected by top and integral end plates. The top and bottom end plates are made of steel and a solid neutron shield. The bottom end plate has a removable HRS access port plug. The TC wall consists of an inner stainless steel liner, a poured-lead shield, a structural carbon steel shell, a solid BISCO-N3 neutron shield, and an outer carbon steel shell. It is hoisted by the trunnions located on its sides, and mates (via transfer trailer) with the access opening of the HSM for transfer of the DSC.

\subsubsection{Hydraulic Ram System (HRS)}

The HRS provides the motive force for transferring the DSC between the HSM and TC. The HRS consists of a single-stage hydraulic cylinder with a grapple assembly and is powered by a hydraulic power unit. The hydraulic cylinder is supported by support frame and is designed to apply pushing or pulling forces of $90 \mathrm{kN}$ ( $20 \mathrm{kip}$ ) during normal operation.

\subsubsection{Operations}

The major operating systems are those required for handling and transferring the fuel from the SFP to the ISFSI for storage, and likewise for removing the fuel from the ISFSI. First, the DSC is placed in the TC, and is lowered into the SFP. After the fuel is loaded into the DSC, the DSC shield plug is placed on the DSC and the TC is raised out of the SFP. The DSC and TC are then decontaminated and drained. The DSC is vacuum dried, pressurized with helium, and sealed. The TC lid is then bolted to the cask, and the TC is lowered horizontally onto a transfer trailer. The TC is transferred to the ISFSI and the cask is mated (top side) to the HSM, as shown in Figure 3.10-4. The HRS arm is inserted through the TC rear access port and pushes the DSC is into the HSM. The TC is then removed and the access steel cover plate is tack welded sealed to the HSM. Unloading procedures are similar to the loading procedures (in reverse).

The decay heat is removed by natural draft convection. Air enters the lower part of the HSM, rises around the DSC, and exits through the top shielded slab. The only required maintenance is the periodic inspection of the air inlet and outlet screens to ensure that they have not been blocked by debris. 


\subsubsection{Reference Documents}

Pacific Nuclear Fuel Services, Inc., "Safety Analysis Report for the Standardized NUHOMS

Horizontal Modular Storage System for Irradiated Nuclear Fuel," NUH-003, Rev. 4A, June 1996.

(Docket No. 72-1004)

U.S. Nuclear Regulatory Commission, Office of Nuclear Material Safety and Safeguards, "Safety Evaluation Report of Pacific Nuclear Fuel Services Safety Analysis Report for the Standardized NUHOMS Horizontal Modular Storage System for Irradiated Nuclear Fuel, (NUH-003, Rev 2)," November 1993. (Docket No. 72-1004)

Pacific Nuclear Fuel Services, Inc., "Topical Report Amendment 2 for the NUTECH Horizontal Moclular Storage System for Irradiated Nuclear Fuel, NUHOMS-24P," (NUH-002, Rev 2). (Docket No. 72-1004)

U.S. Nuclear Regulatory Commission, Office of Nuclear Material Safety and Safeguards, "Safety Evaluation Report Related to the TR for the NUTECH Horizontal Modular Storage System for Irradiated Nuclear Fuel Submitted by NUTECH Engineers, Inc., NUH-002, Rev 1A," April 1989. (Docket No. 72-1004) 


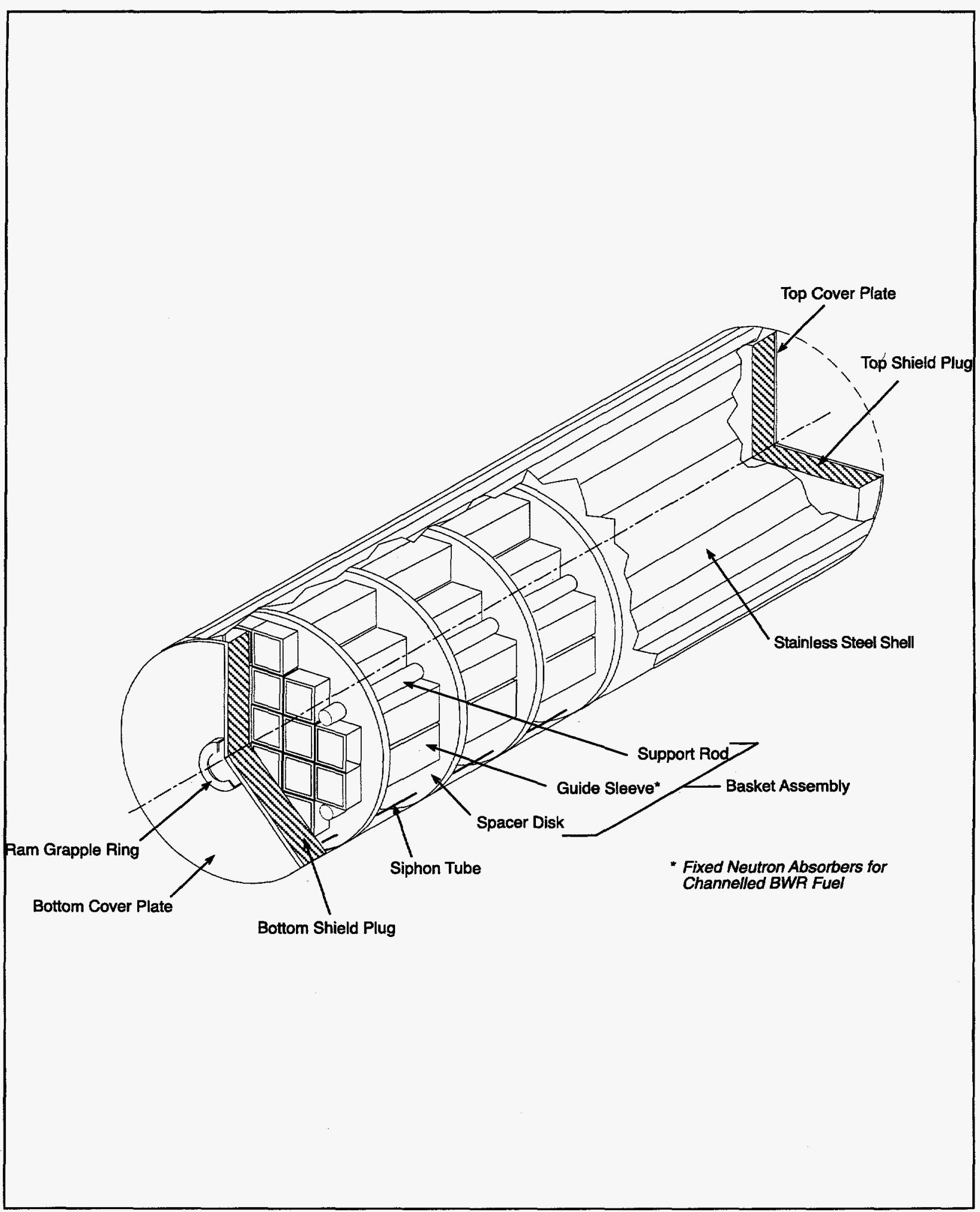

Figure 3.11-1 Diagram of the Standardized NUHOMS DSC 


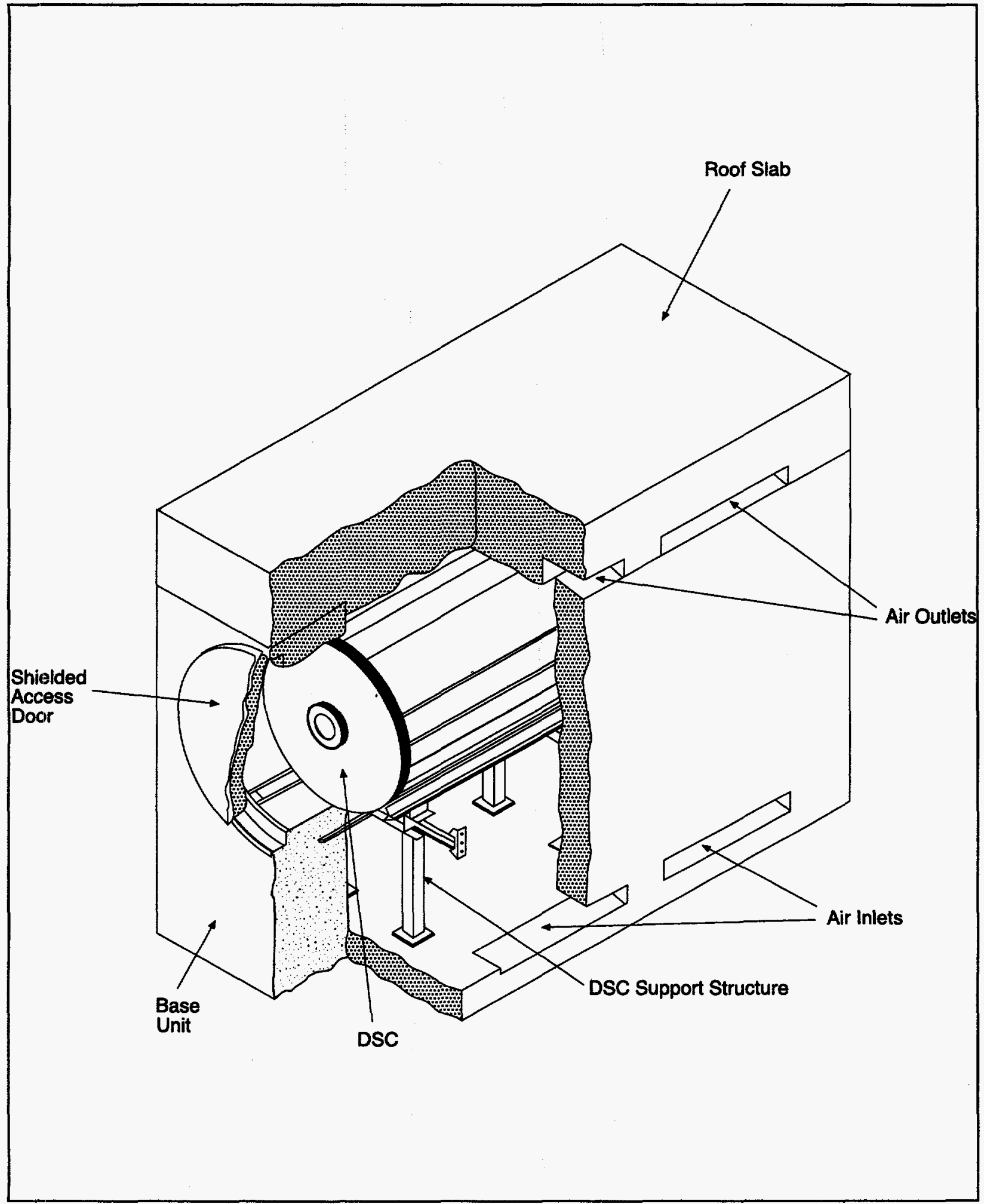

Figure 3.11-2 Diagram of the Standardized NUHOMS HSM 


\subsection{TN-40}

The TN-40, made by Transnuclear, Inc., is a metal DCSS designed to vertically store 40 PWR SFAs. The cask is approximately $5.1 \mathrm{~m}(16.7 \mathrm{ft})$ high and $2.6 \mathrm{~m}(8.5 \mathrm{ft})$ in diameter. It weighs approximately 109 metric tons (120 tons) when fully loaded. The TN-40 is designed to store 40 PWR SFAs. The TN-40 is currently in use at the Prairie Island ISFSI. A diagram of the cask is shown in Figure 3.12-1. A photograph of the TN-40 is shown in Figure 3.12-2.

\subsubsection{Cask Body}

The cask body consists of an inner shell which is a welded carbon steel cylinder, approximately 3.8 $\mathrm{cm}$ ( $1.5 \mathrm{in}$.) thick, with an integrally welded carbon steel bottom closure $26 \mathrm{~cm}$ (10.25 in.) thick, and a welded flange forging for the lid. The primary lid is a flanged carbon steel lid, $26.7 \mathrm{~cm}(10.5 \mathrm{in}$.) thick, is bolted to the inner shell flange with double metallic O-rings. A polypropylene disk enclosed in steel, $11.4 \mathrm{~cm}$ ( $4.5 \mathrm{in}$.) thick, is bolted to the primary lid. A steel torispherical cover is also installed on top of the containment lid for weather protection. Gamma shielding is provided by an independent wall of carbon steel approximately $24 \mathrm{~cm}$. (9.5 in.) thick that is welded to the bottom shield plate and to the closure flange of the inner shell. Neutron shielding is provided by a resin compound of borated polyester enclosed in long, slender aluminum containers, approximately 10.8 $\mathrm{cm}$ (4.3 in.) thick, that surround the carbon steel wall. A smooth outer steel shell, approximately 1.3 $\mathrm{cm}(0.5 \mathrm{in}$.) thick, constructed of two half-cylinders encloses the neutron shield. The cask cavity surfaces and the outer carbon steel wall have a sprayed metallic coating of $\mathrm{Zn} / \mathrm{Al}$ for corrosion protection. Four trunnions are connected to the cask body for lifting and rotating the cask.

The fuel basket within the cask is a grid structure consisting of an assembly of stainless steel cells, separated by aluminum and Boral poison plates (for criticality control).

\subsubsection{Operations}

The major operating systems are those required for handling and transferring the fuel from the SFP to the ISFSI for storage, and likewise for removing the fuel from the ISFSI. The cask is loaded underwater in the SFP and the flanged carbon steel lid is placed on the cask. The cask is then lifted to the pool surface, the lid is bolted, and the cask is drained. Next, it is vacuum dried, pressurized with helium, and decontaminated. The polypropylene neutron shield disk and steel cover are then installed, and a pressure-monitoring device is installed in the double-seal interspace. The cask is then transferred to the ISFSI site and is set in place on the concrete pad. The pressure-monitoring system is externally connected and will notify plant operators of a loss of seal integrity. Unloading procedures are similar to the loading procedures (in reverse). 
The cask is a totally passive system with natural cooling sufficient to maintain safe fuel cladding temperatures. The cask walls provide adequate shielding, and no radioactive products are released under any credible conditions. Normal radiation survey monitoring of the ISFSI is also performed.

\subsubsection{Reference Documents}

Northern States Power Company, "Prairie Island Independent Spent Fuel Storage Installation

Technical Specifications and Safety Analysis Report," Rev. 4, October 1995. (Docket No. 72-10)

Northern States Power Company, "Prairie Island Nuclear Generating Plant Safety Evaluation No. 344, Independent Spent Fuel Storage Installation," May 4, 1993. (Docket 72-10)

U.S. Nuclear Regulatory Commission, Office of Nuclear Materials Safety and Safeguards, "Safety Evaluation Report for the Prairie Island Independent Spent Fuel Storage Installation," July 1993.

(Docket 72-10) 


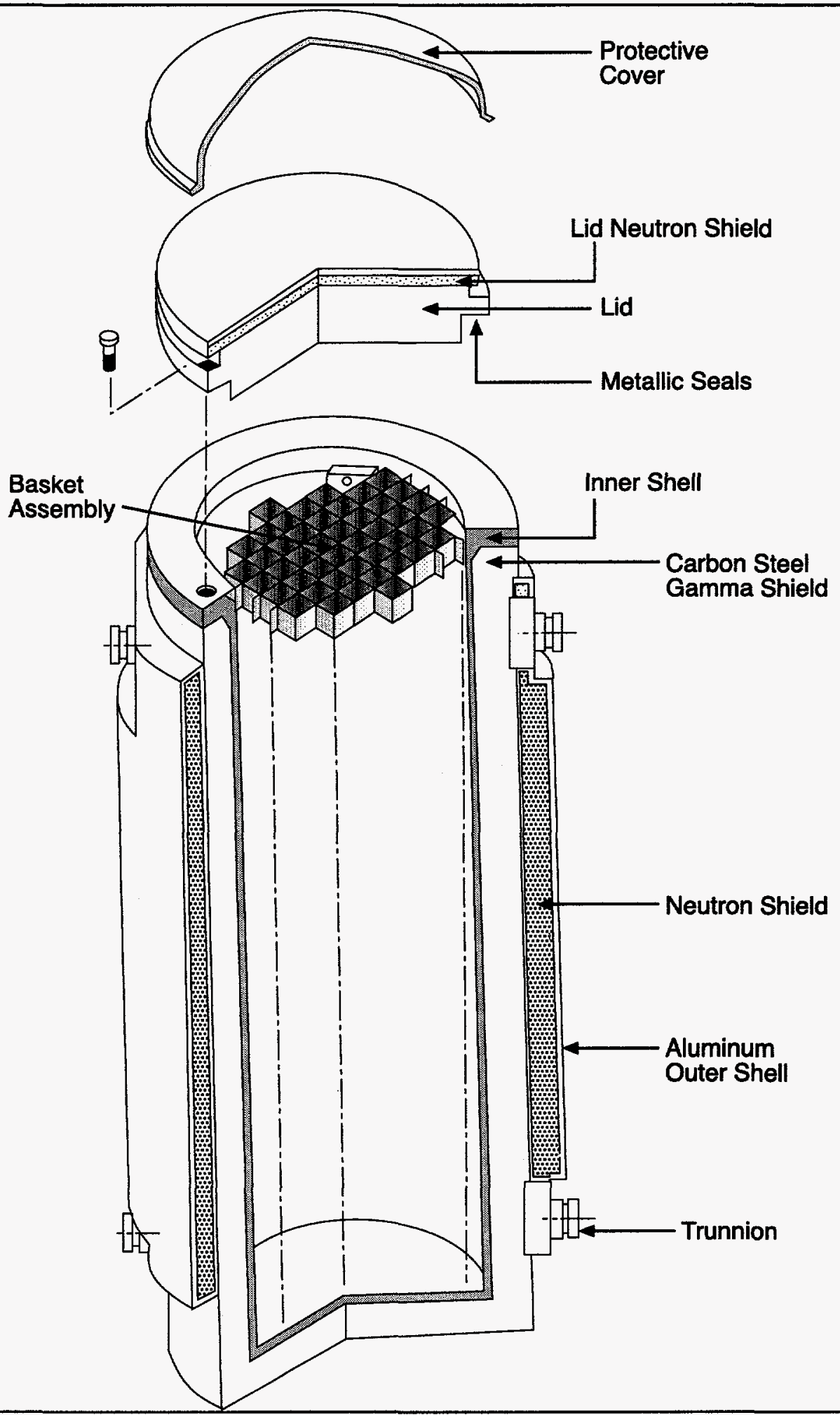

Figure 3.12-1 Diagram of the TN-40 


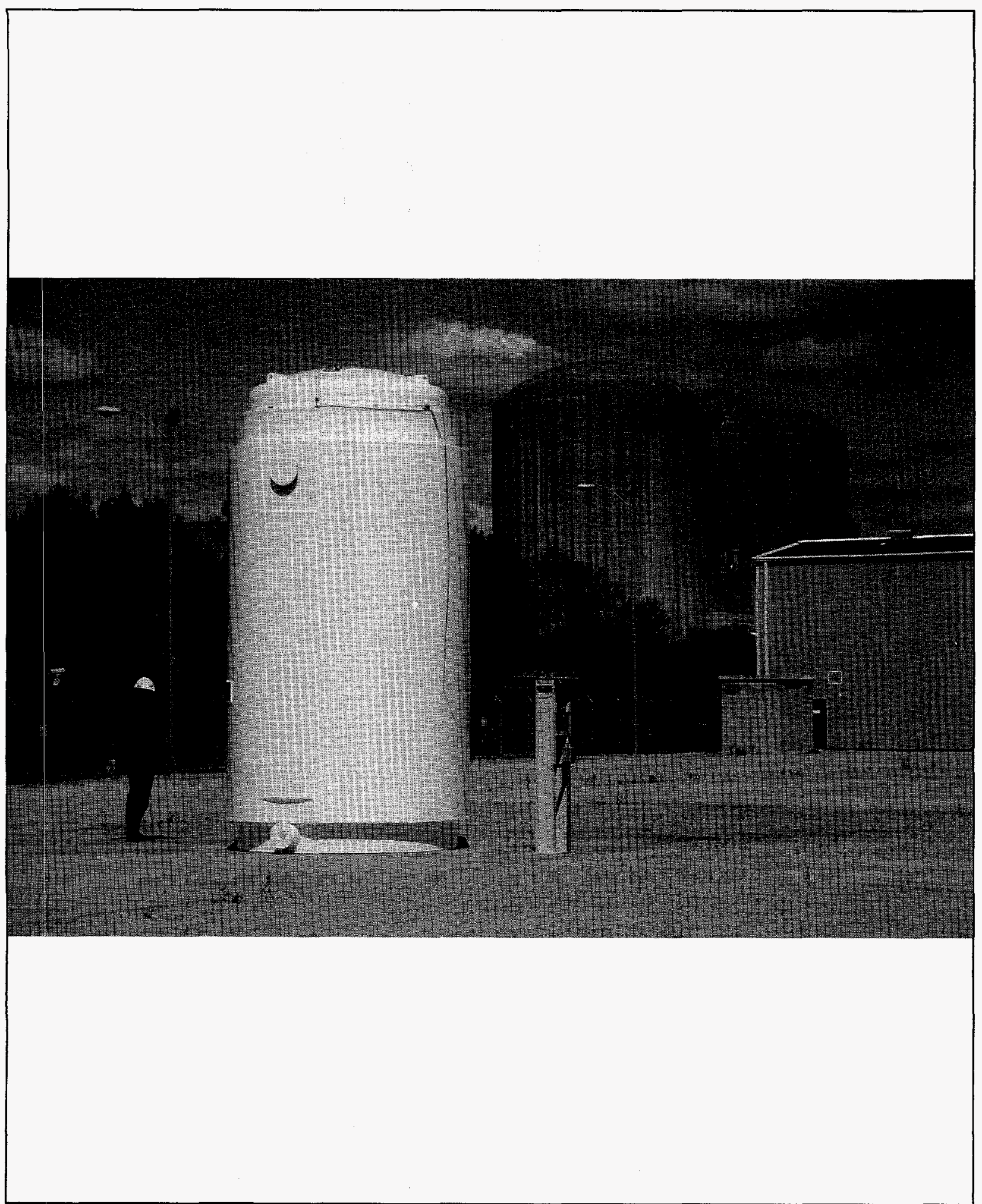

Figure 3.12-2 Photograph of the TN-40 


\subsection{TN-24: Certificate of Compliance \# 1005}

The TN-24, made by Transnuclear, Inc., is a metal DCSS designed to vertically store 24 PWR SFAs. The cask is approximately $5.1 \mathrm{~m}(16.7 \mathrm{ft})$ high and $2.4 \mathrm{~m}(7.9 \mathrm{ft})$ in diameter. It weighs approximately 103 tonnes (113 tons) when fully loaded with fuel and water. The TN-24 is currently not in use at any existing ISFSIs. A diagram of the cask is shown in Figure 3.13-1.

\subsubsection{Cask Body}

The cask body consists of a inner forged steel cylinder, $24.8 \mathrm{~cm}$ (10 in.) thick, with an integrallywelded forged steel bottom closure $28.6 \mathrm{~cm}$ (11 in.) thick, and a welded flange forging for the lid. The primary lid is a flanged forged steel lid, $29.2 \mathrm{~cm}$ (11.5 in.) thick, bolted to the cylinder flange with double metallic O-ring seals. A polypropylene disk enclosed in steel, $11.4 \mathrm{~cm}(4.5 \mathrm{in}$.) thick, is bolted to the primary lid. A steel torispherical cover is also installed on top of the containment lid for weather protection. Gamma shielding is provided by the cylinder wall, and neutron shielding is provided by a resin compound of borated polyester enclosed in long, slender aluminum containers, approximately $13.7 \mathrm{~cm}(5.4 \mathrm{in}$.) thick, that surround the forged steel wall. A smooth outer steel shell, approximately $2 \mathrm{~cm}(0.75 \mathrm{in}$.) thick, constructed of two half-cylinders encloses the neutron shield. The cask cavity surfaces and the outer carbon steel wall have a thermally sprayed metallic coating of $\mathrm{Zn} / \mathrm{Al}$ for corrosion protection. The cavity also has a second coat of Ti/Al oxide to provide high thermal emissivity. The external surfaces are painted for ease of decontamination. Four trunnions are connected to the cask body for lifting and rotating the cask.

The fuel basket within the cask is a grid structure of mechanically interlocking borated stainless steel plates (for criticality control), with a copper coating,, on an aluminum alloy frame.

\subsubsection{Operations}

The major operating systems are those required for handling and transferring the fuel from the SFP to the ISFSI for storage, and likewise for removing the fuel from the ISFSI. The cask is loaded underwater in the SFP and the flanged carbon steel lid is placed on the cask. The cask is then lifted to the pool surface, the lid is bolted, and the cask is drained. Next it is vacuum dried, pressurized with helium, and decontaminated. The polypropylene neutron shield disk and steel cover are then installed, and a pressure-monitoring device is installed in the double-seal interspace. The cask is then transferred to the ISFSI site and is set in place on the concrete pad. The pressure-monitoring system is externally connected and will notify plant operators of a loss of seal integrity. Unloading procedures are similar to the loading procedures (in reverse). 
The cask is a totally passive systems with natural cooling sufficient to maintain safe fuel cladding temperatures. The cask wall provides adequate shielding, and no radioactive products are released under any credible conditions. Normal radiation survey monitoring of the ISFSI is also performed.

\subsubsection{Reference Documents}

Transnuclear, Inc., "TN-24 Dry Storage Cask Topical Report," Rev. 2A, Hawthorne, NY, December 1989. (Docket 72-1005)

U.S. Nuclear Regulatory Commission, Office of Nuclear Material Safety and Safeguards, "Safety Evaluation Related to the Topical Report for the TN-24 Storage Cask Submitted by Transnuclear, Inc.," July 1989. (Docket 72-1005) 


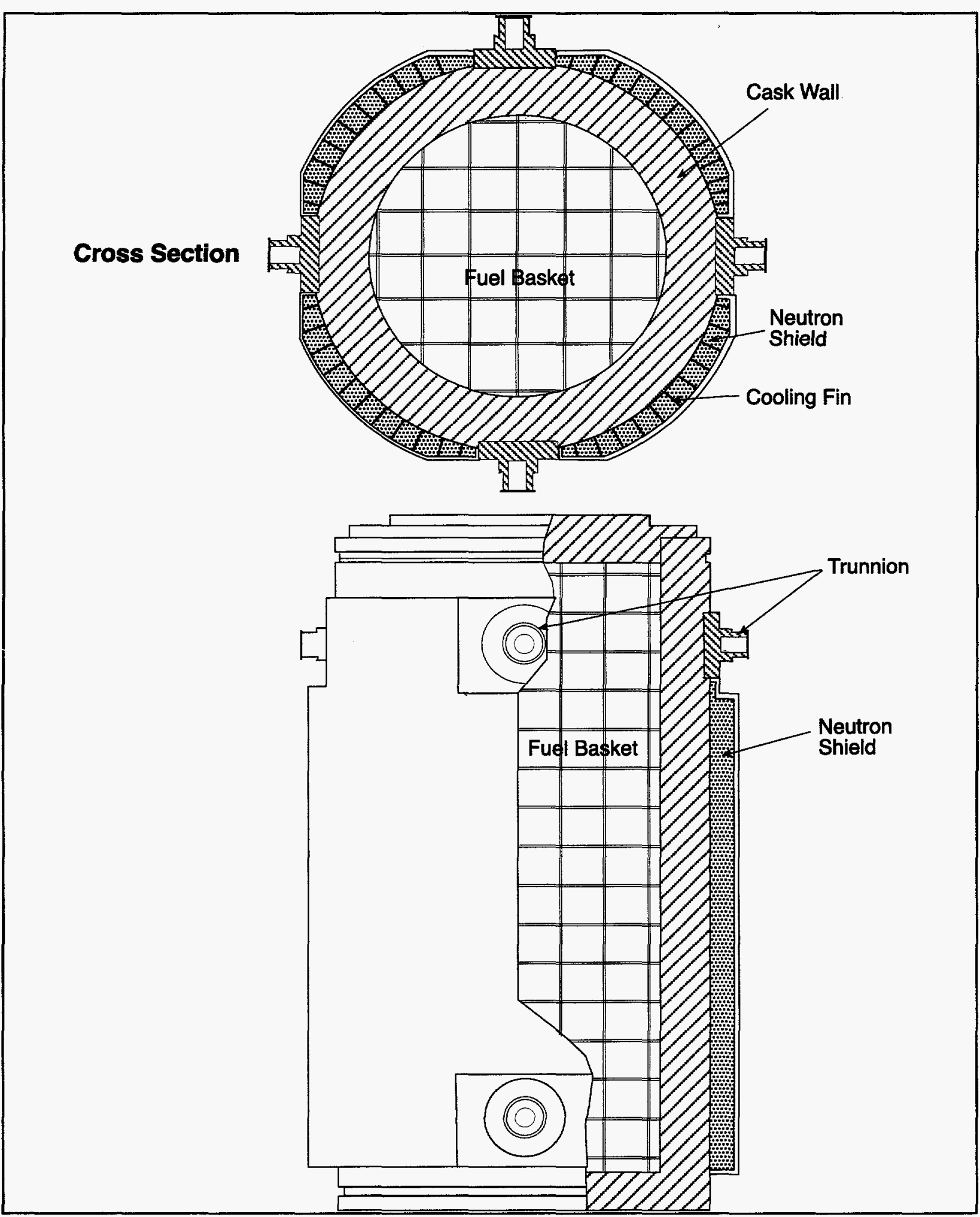

Figure 3.13-1 Diagram of the TN-24 
Figure 3.13-2 Intentionally Left Blank 


\subsection{VSC-24: Certificate of Compliance \# 1007}

The ventilated storage cask system (VSC-24), made by Sierra Nuclear Corporation, is a concrete DCSS designed to vertically store 24 PWR SFAs. The principal components of the system are a steel multi-assembly sealed basket (MSB), a ventilated concrete cask (VCC), and an MSB transfer cask (MTC). The VSC-24 is currently used at Palisades and Point Beach, and is planned for use at Arkansas Nuclear One. A diagram of the cask is shown in Figure 3.14-1. A photograph of the cask is shown in Figure 3.14-2.

\subsubsection{Multi-Assembly Sealed Basket (MSB)}

The MSB is shown in Figure 3.14-3. The MSB consists of a steel cylindrical shell with a thick shield plug and steel cover plates welded at each end. The shell length is fuel-specific and varies from 4.1 to $4.6 \mathrm{~m}$ (13.8 to $15.1 \mathrm{ft})$, the diameter is $1.6 \mathrm{~m}(5.3 \mathrm{ft})$, and the shell thickness is $2.5 \mathrm{~cm}(1 \mathrm{in}$.). The MSB weighs approximately 29 tonnes ( 32 tons). The internal steel basket consists of a welded structure with 24 square storage locations. The basket aids in the insertion of the fuel assemblies, enhances subcriticality during loading operations, and provides structural support during a potential drop accident. The basket is coated with a Carbo Zinc 11 coating for corrosion protection.

\subsubsection{Ventilated Concrete Cask (VCC)}

The VCC is a reinforced-concrete cask in the shape of a hollow right circular cylinder. The VCC has four penetrations for air entry (located at the bottom of the VCC) and four outlets located at the top. The penetrations are protected from debris intrusion by wire mesh screens. The internal cavity of the VCC as well as the inlets and outlets are steel lined. After the MSB is inserted, a shield ring is placed over the MSB/VCC gap and the cask weather cover is installed. The VCC height is fuel-specific and varies from 5.0 to $5.4 \mathrm{~m}(16.4 \mathrm{ft}$ to $17.7 \mathrm{ft})$ high. The outer diameter is approximately $3.4 \mathrm{~m}(11.2 \mathrm{ft})$, and the walls consist of $70 \mathrm{~cm}$ ( $29 \mathrm{in})$ thick concrete and a $4.5 \mathrm{~cm}$ (1.75 in) thick steel liner. Total weight of the VCC and MSB (loaded and with lids) is 121 tonnes (133 tons).

\subsubsection{MSB Transfer Cask (MTC)}

The MTC is a shielded lifting device with inner and outer structural steel cylinders which house lead and solid RX-277 neutron shield cylinders designed to reduce radiation from the fuel inside the MSB/MTC. The MTC functions to transfer the MSB from the spent fuel pool to the VCC inside the fuel pool building.

\subsubsection{Operations}

The major operating systems are those required for handling and transferring the fuel from the SFP to the ISFSI for storage, and likewise for removing the fuel from the ISFSI. The major steps are shown in Figure 3.14-5. First, the MSB is placed in the MTC, and is lowered into the SFP. After the fuel is 
loaded into the MSB, the MSB shield lid is placed on the MSB and the MTC is raised out of the SFP. The MSB and MTC are then decontaminated and drained. The MSB is vacuum dried, pressurized with helium, and sealed by welding. The MSB is then transferred to the VCC. The VCC is finally sealed and is transferred to the concrete pad. Unloading procedures are similar to the loading procedures (in reverse).

The decay heat is removed passively by natural draft convection. Air enters the lower part of the VCC, rises around the MSB, and exits through the top. The system is self regulating, and the only required maintenance is the periodic inspection of the air inlet and outlet screens to ensure that they have not been blocked by debris. Normal radiation monitoring is also performed.

\subsubsection{Reference Documents}

Pacific Sierra Nuclear, "Topical Report on the Ventilated Storage Cask System for Irradiated Fuel," Rev. 2, July 1990. (Docket 72-1007)

U.S. Nuclear Regulatory Commission, Office of Nuclear Material Safety and Safeguards, "Safety Evaluation Report for Pacific Sierra Nuclear Topical Report on the Ventilated Storage Cask System for Irradiated Fuel, Rev. 2," March 1991. (Docket 72-1007) 


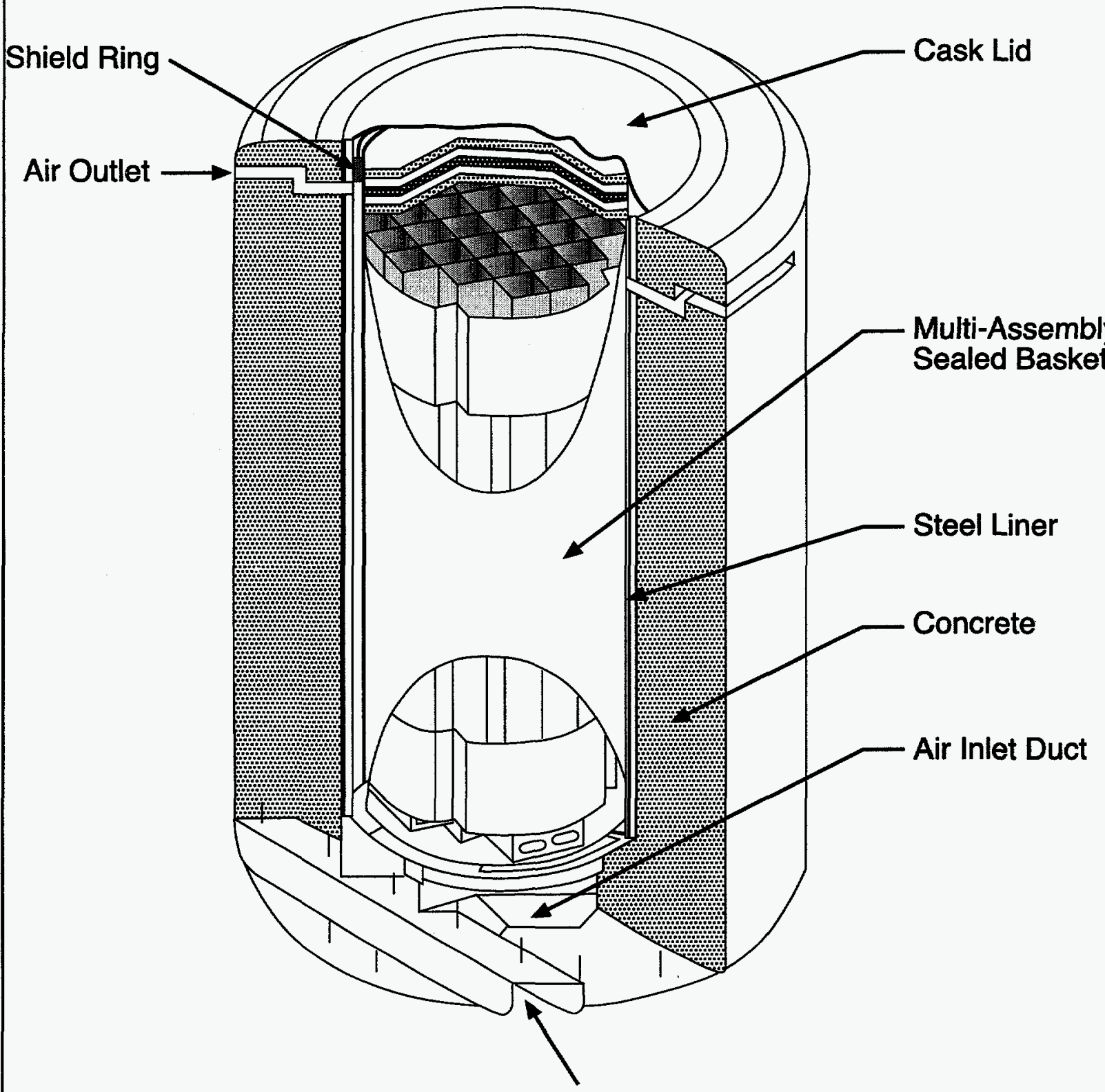

Air Entrance

Figure 3.14-1 Diagram of the VSC-24 


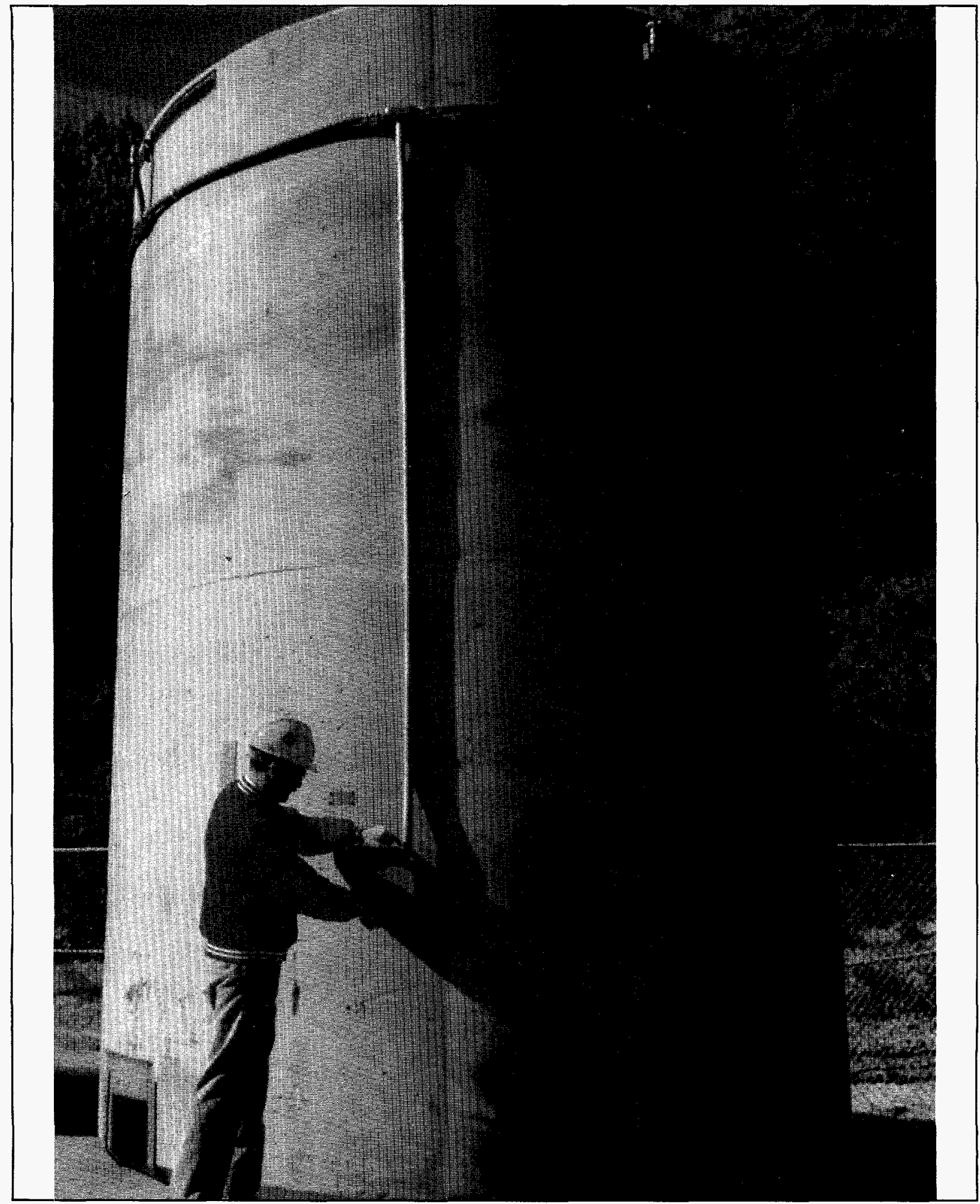

Figure 3.14-2 Photograph of the VSC-24 


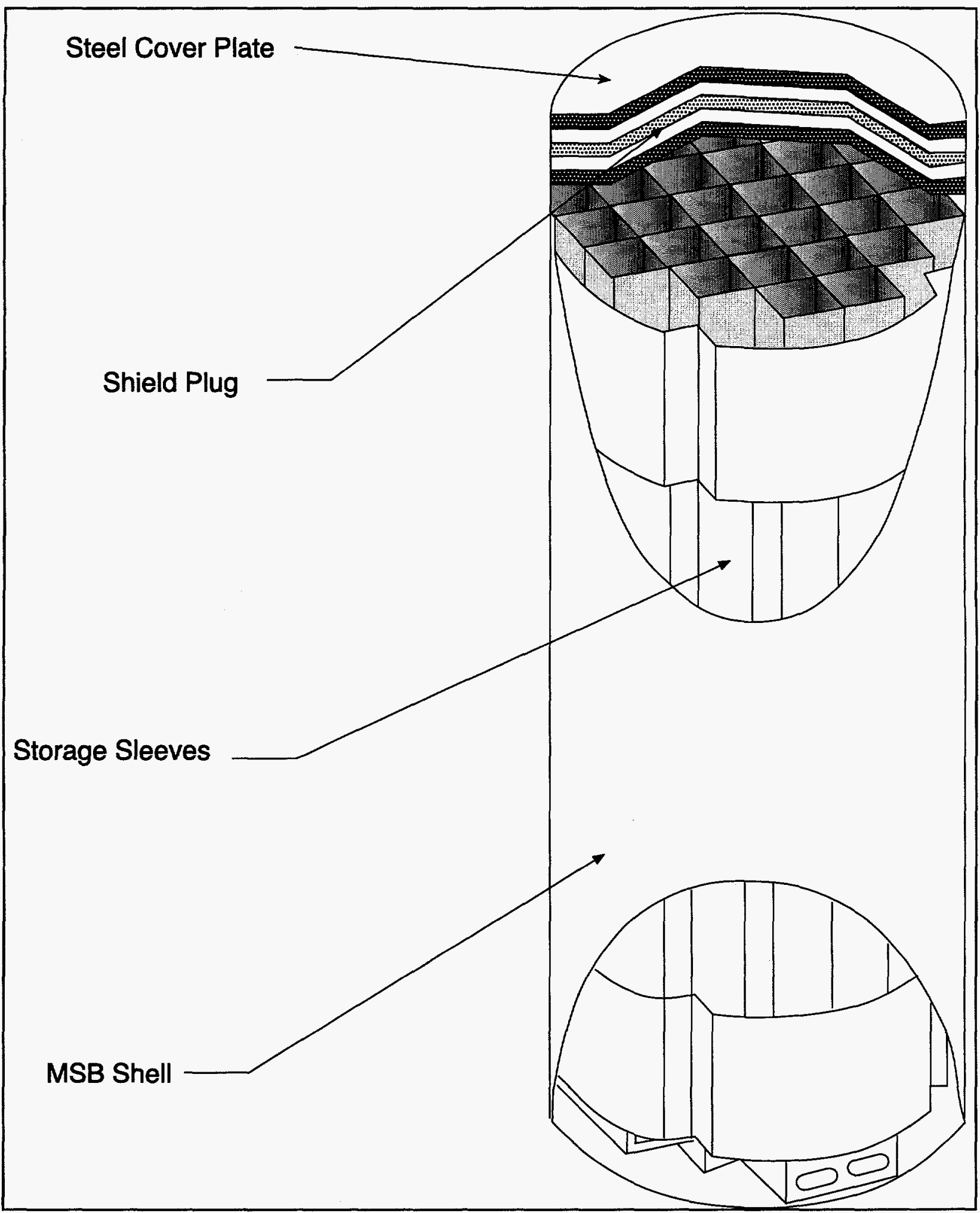

Figure 3.14-3 Diagram of the VSC-24 MSB 


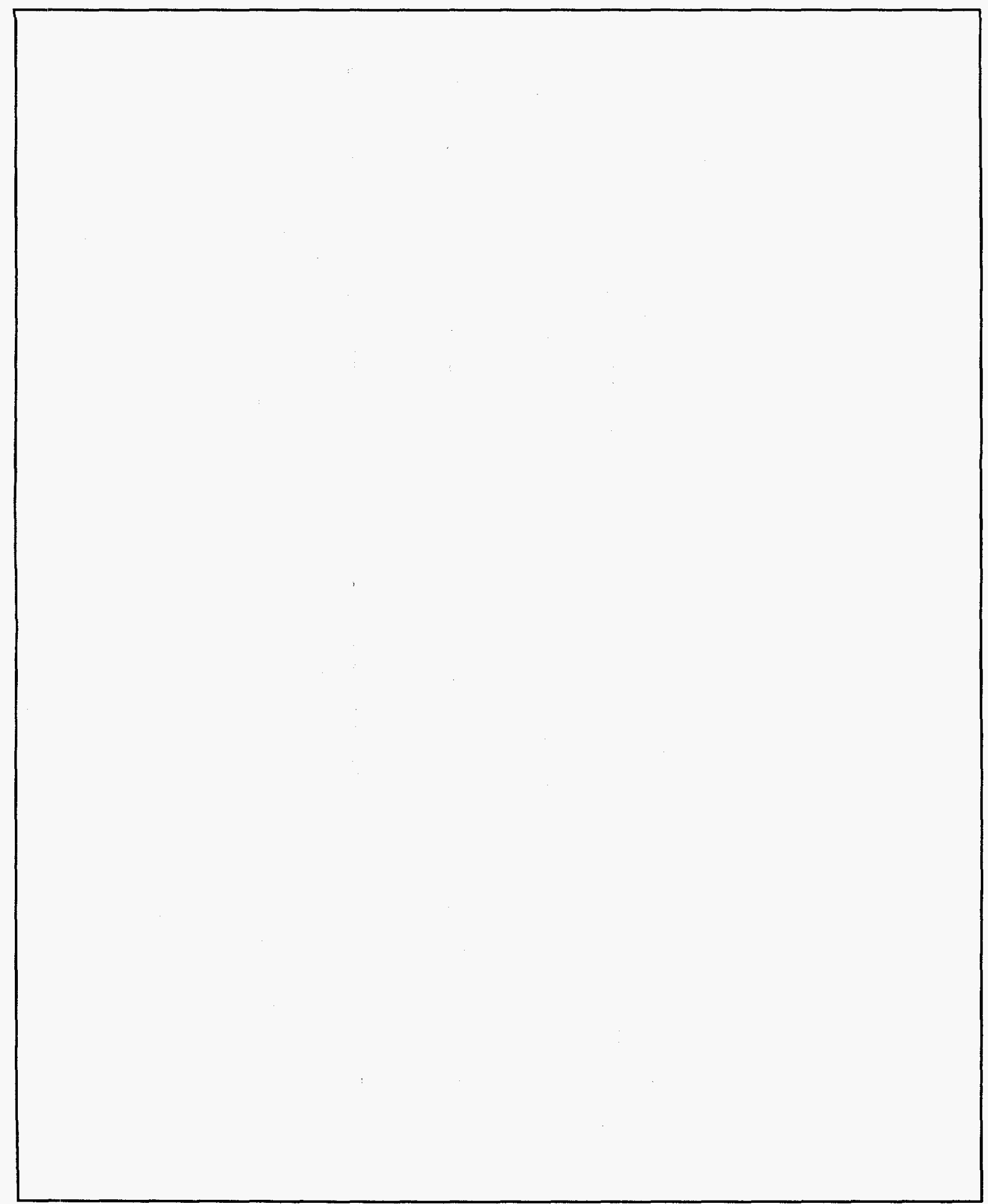

Figure 3.14-4 Intentionally Left Blank 


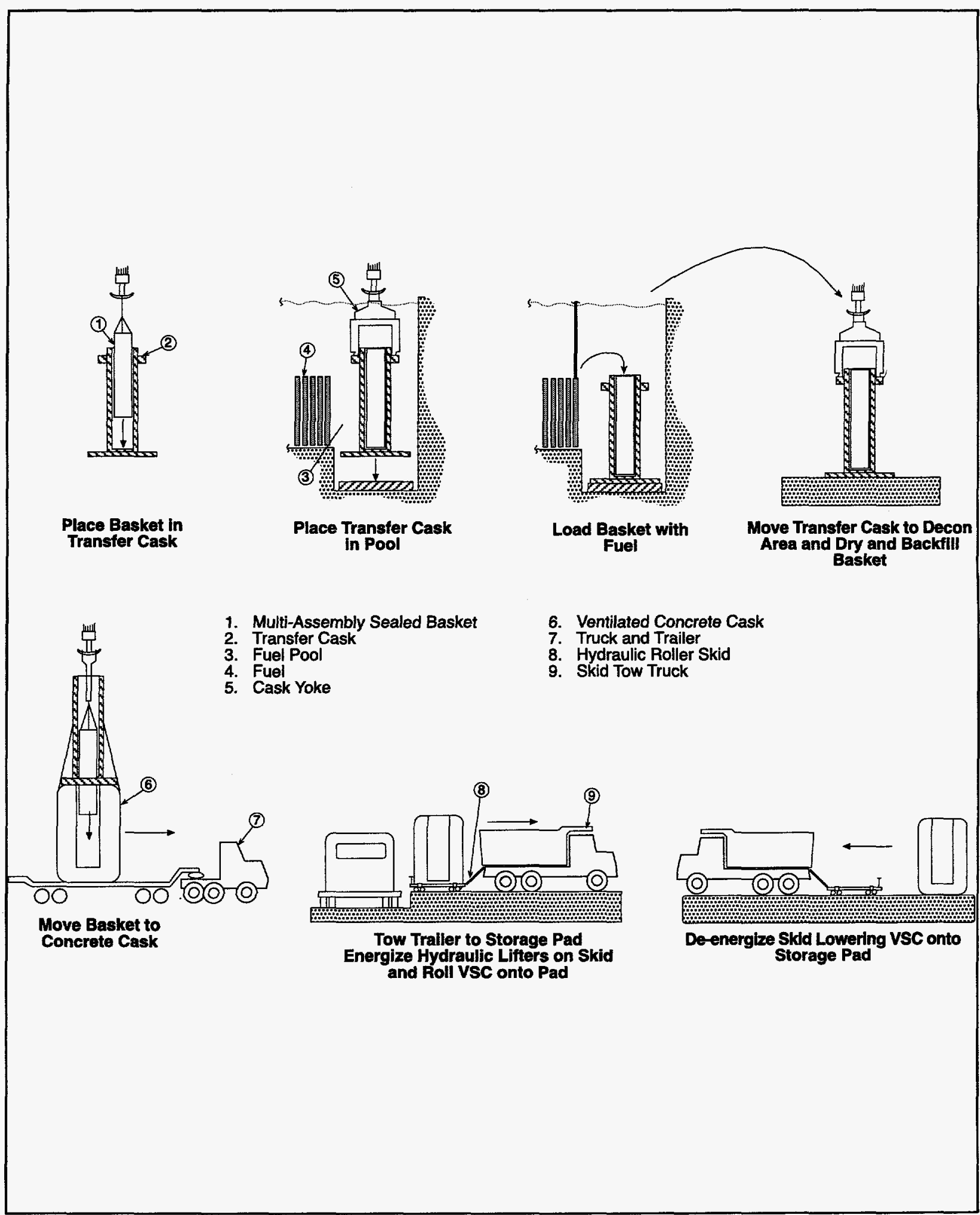

Figure 3.14-5 VSC-24 Fuel-Handling Operations 


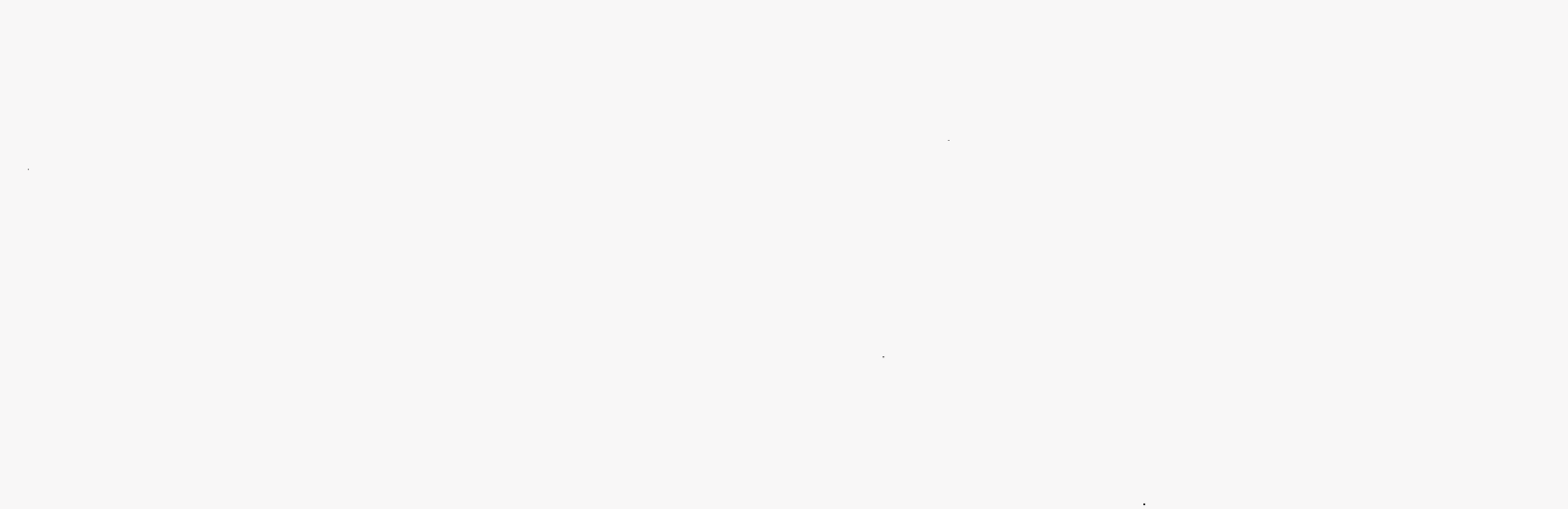




\section{SITE-SPECIFIC ISFSIS}

This section contains information on all ISFSI sites currently operating under a site-specific license. As discussed in Section 2.1, all site-specific ISFSIs and associated DCSS designs must be individually authorized and licensed by the NRC under 10 CFR Part 72. Details of the DCSS designs used at each site-specific ISFSI are in Section 3. Site-Specific ISFSIs storing spent fuel are summarized in Table 4.1.

Table 4.1 Site Specific ISFSI Sites Storing Fuel

\begin{tabular}{|c|c|c|c|c|}
\hline ISFSI & Operator & $\begin{array}{l}\text { License } \\
\text { Date }\end{array}$ & DCSS & $\begin{array}{c}\text { No. of Loaded } \\
\text { Casks (Sept. } \\
1996) \\
\end{array}$ \\
\hline Calvert Cliffs & $\begin{array}{l}\text { Baltimore Gas and Electric } \\
\text { Company }\end{array}$ & $11 / 25 / 90$ & NUHOMS-24P & 14 \\
\hline Fort St. Vrain & $\begin{array}{c}\text { Public Service Company of } \\
\text { Colorado } \\
\end{array}$ & $11 / 04 / 91$ & $\begin{array}{l}\text { Modular Vault } \\
\text { Dry Storage } \\
\end{array}$ & $1482 *$ \\
\hline H.B. Robinson & $\begin{array}{c}\text { Carolina Power and Light } \\
\text { Company }\end{array}$ & $08 / 13 / 86$ & NUHOMS-7P & 8 \\
\hline Oconee & Duke Power Company & $01 / 29 / 90$ & NUHOMS-24P & 34 \\
\hline Prairie Island & Northern States Power Company & $10 / 19 / 93$ & $\mathrm{TN}-40$ & 3 \\
\hline \multirow[t]{4}{*}{ Surry } & \multirow[t]{4}{*}{$\begin{array}{c}\text { Virginia Electric \& Power } \\
\text { Company }\end{array}$} & $07 / 02 / 86$ & Castor V/21 & 25 \\
\hline & & $02 / 15 / 90$ & $\mathrm{MC}-10$ & 1 \\
\hline & & $05 / 16 / 90$ & NAC-I28 S/T & 2 \\
\hline & & $06 / 29 / 94$ & Castor X/33 & 1 \\
\hline
\end{tabular}

* A total of 1,482 high-temperature, gas-cooled (HTGC) reactor fuel elements are in dry storage at the Fort St. Vrain MVDS ISFSI. 


\subsection{Calvert Cliffs ISFSI (Docket 72-8)}

\begin{tabular}{cccc}
\hline License No. & Issue date & Expiration date & DCSS \\
\hline SNM-2505 & $11 / 25 / 92$ & $11 / 30 / 12$ & NUHOMS-24P \\
\hline
\end{tabular}

The Calvert Cliffs ISFSI employs the NUHOMS-24P system, designed by VECTRA Technologies (see Section 3.10). It is licensed for a capacity of 120 NUHOMS-24P modules holding a total of 2880 SFAs. The ISFSI currently has 14 modules loaded.

\subsubsection{History}

The Calvert Cliffs nuclear power plant, owned and operated by Baltimore Gas and Electric Company (BG\&E), received its license to store fuel in an ISFSI on November 25, 1992. The Calvert Cliffs ISFSI has been designed as a life-of-plant storage facility. The ISFSI will have the capacity to store all spent fuel discharged from Calvert Cliffs Units 1 and 2, beyond the SFP, up to the 40-year plant life, if necessary. Because the exact capacity needed is uncertain, BG\&E has elected to construct the ISFSI in five phases.

\subsubsection{General Description of the Installation}

As shown in Figure 4.1-1, the Calvert Cliffs nuclear power plant is located on the west shore of the Chesapeake Bay in Calvert County, Maryland. The location of the ISFSI in relation to the site is shown in Figure 4.1-2, and photographs of the ISFSI are shown in Figures 4.1-3 and 4.1-4. The ISFSI is located outside the protected area within the owner-controlled area approximately $701 \mathrm{~m} \mathrm{(2300 \textrm {ft } )}$ southwest of the plant. The current phase of the ISFSI has four $2 \times 6$ arrays for a total of 48 modules.

\subsubsection{Reference Documents}

U.S. Nuclear Regulatory Commission, Office of Nuclear Material Safety and Safeguards, "Environmental Assessment Related to Construction and Operation of the Calvert Cliffs Independent Spent Fuel Storage Installation," Baltimore Gas and Electric Company, March 1991. (Docket 72-8)

U.S. Nuclear Regulatory Commission, Office of Nuclear Material Safety and Safeguards, "Safety Evaluation Report for the Baltimore Gas and Electric Company's Safety Analysis Report for an Independent Spent Fuel Storage Installation at Calvert Cliffs," November 1992. (Docket 72-8)

Baltimore Gas and Electric Company (BG\&E), "Calvert Cliffs Independent Spent Fuel Storage Installation Safety Analysis Report," Rev. 1, July 1992. (Docket 72-8) 


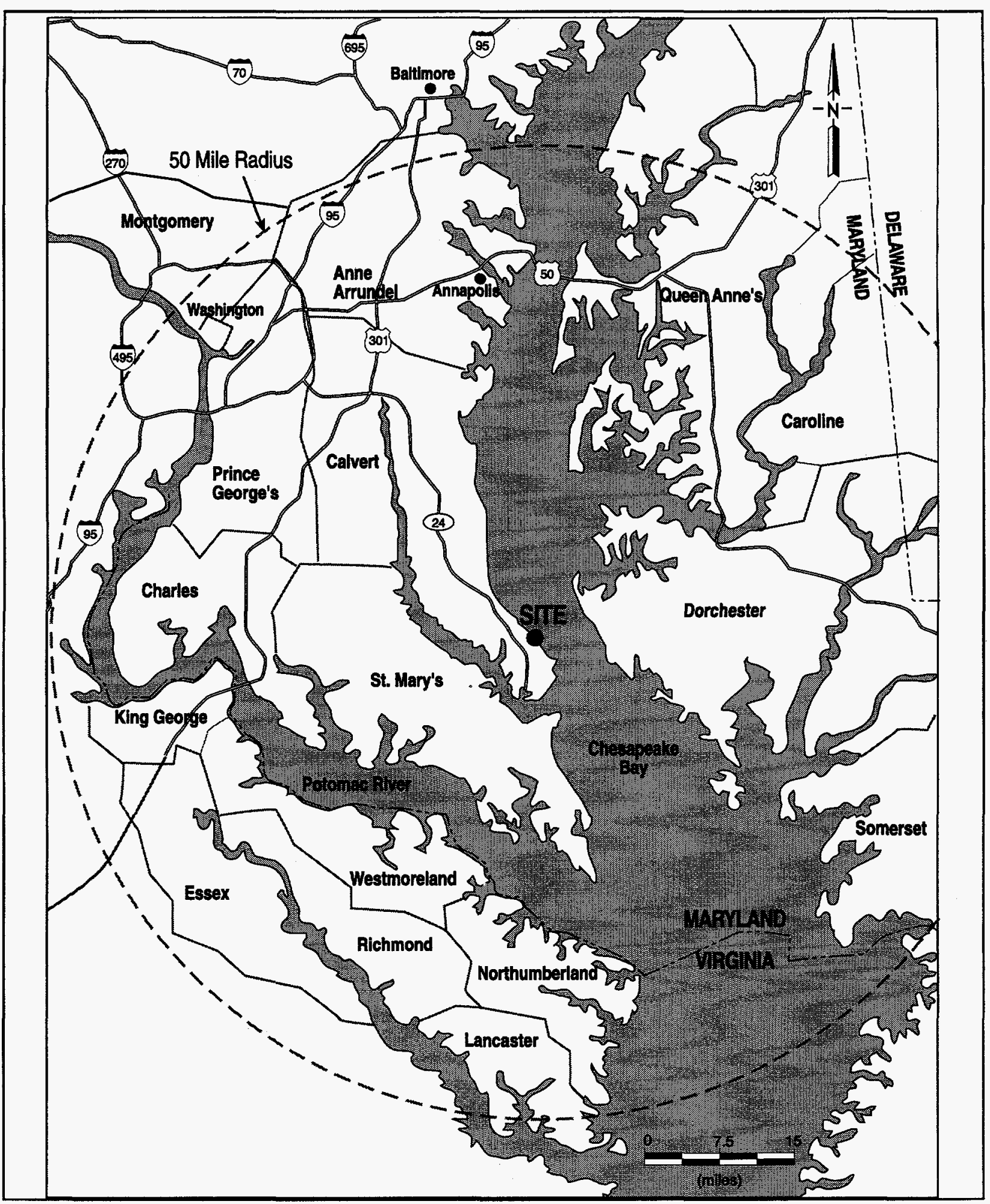

Figure 4.1-1 Calvert Cliffs Nuclear Power Plant Area Map 


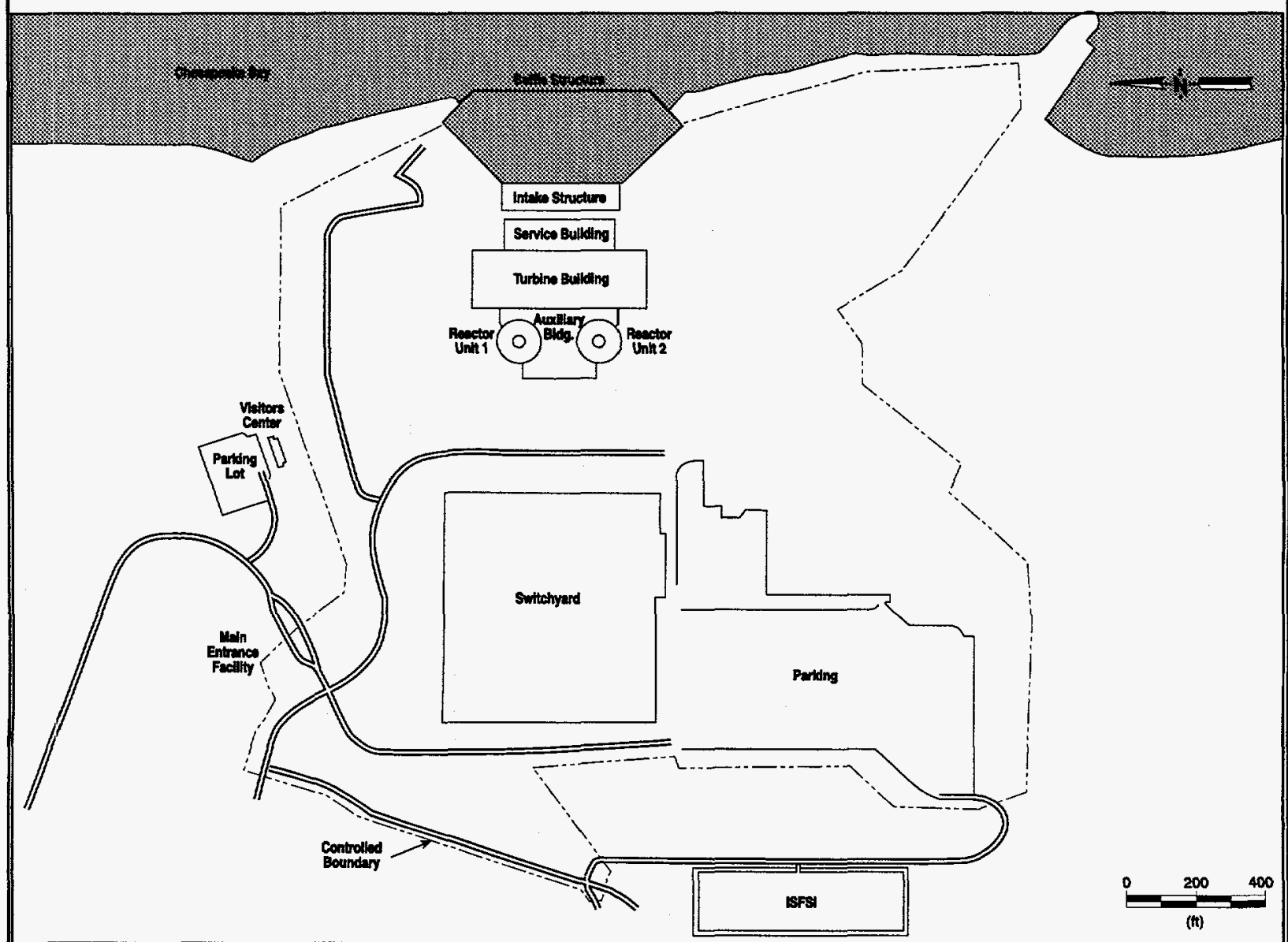

Figure 4.1-2 Calvert Cliffs Nuclear Power Plant Site Map 


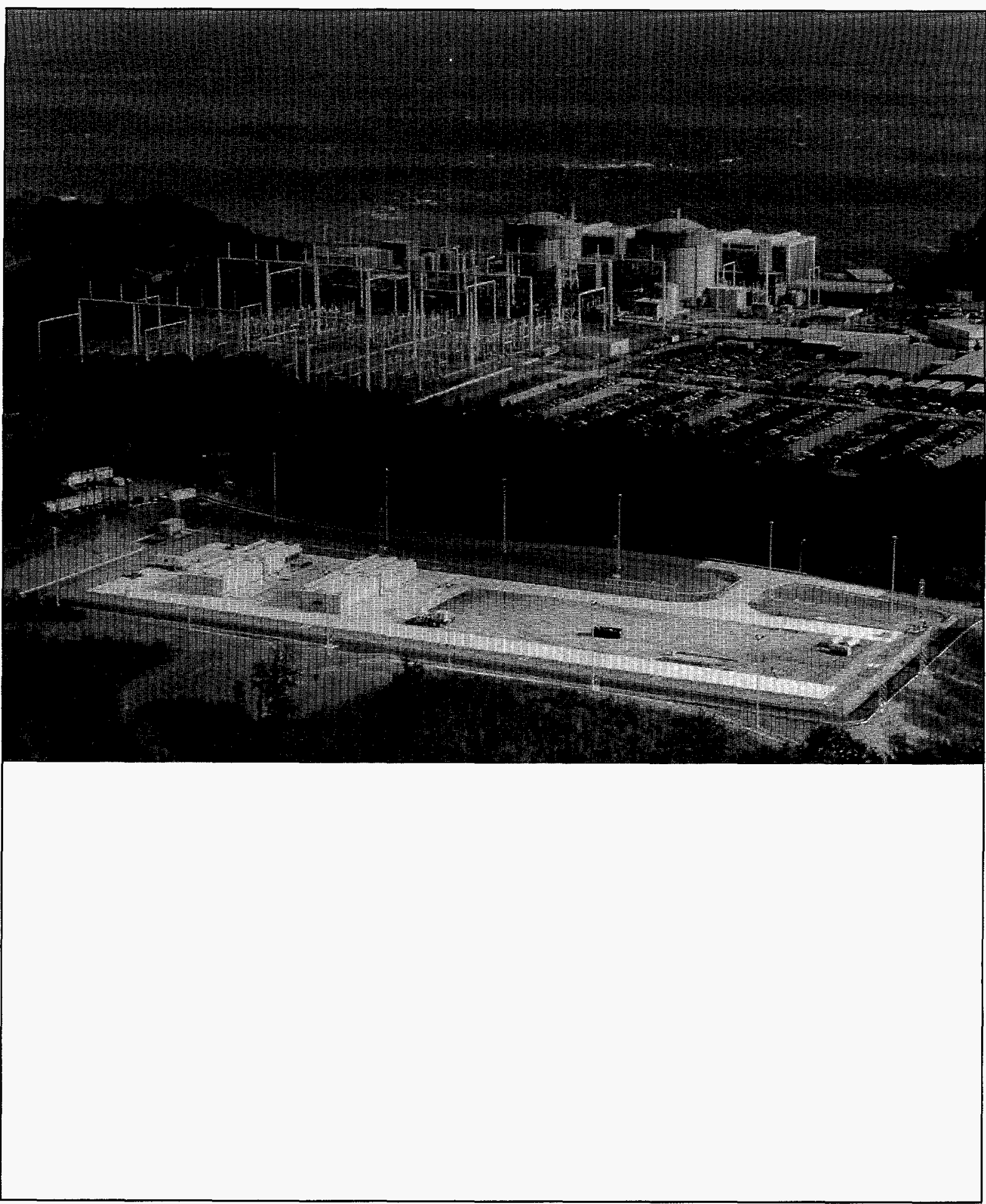

Figure 4.1-3 Photograph of the Calvert Cliffs ISFSI 


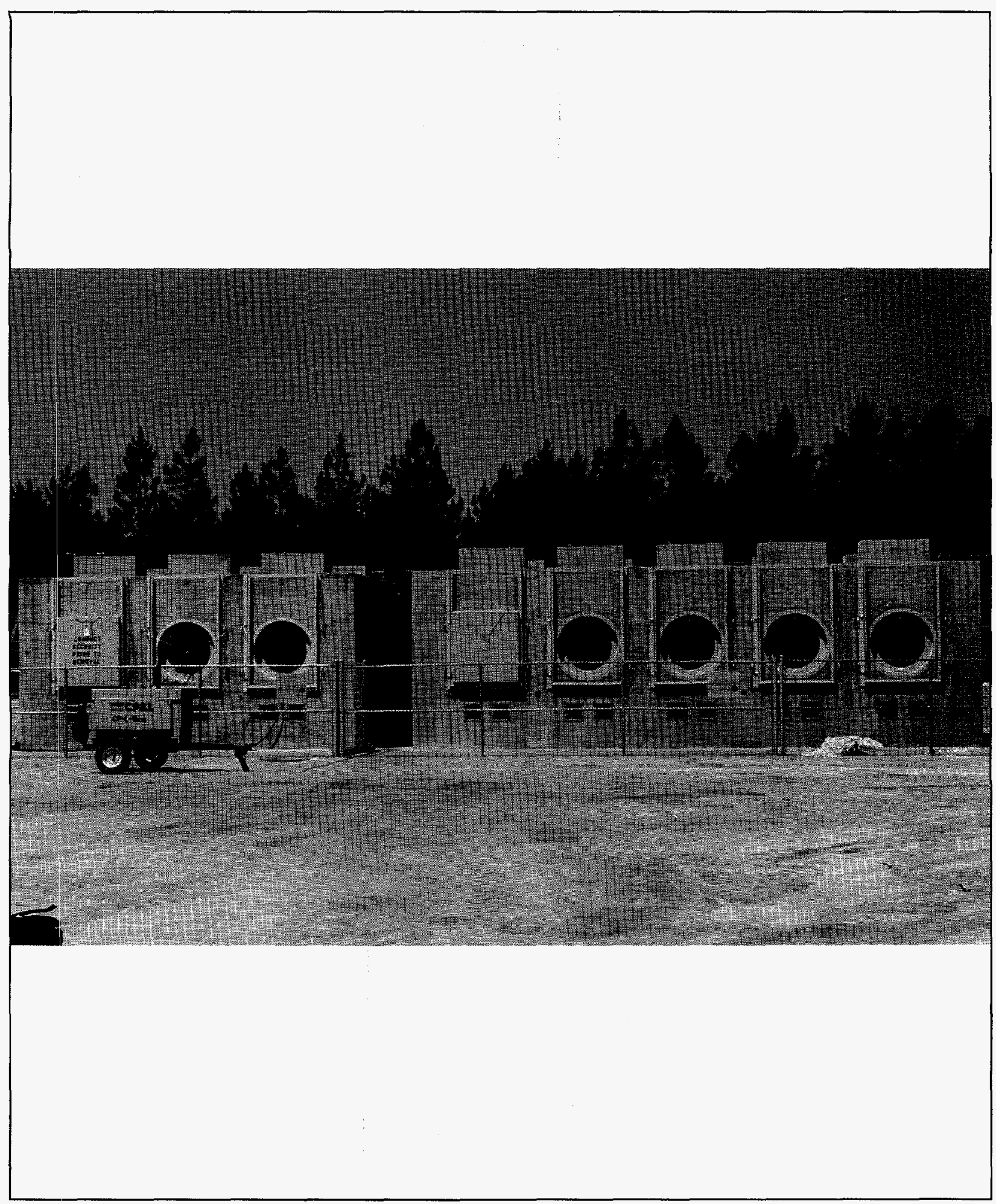

Figure 4.1-4 Photograph of the Calvert Cliffs ISFSI (Close-up) 


\subsection{Fort St. Vrain ISFSI (Docket 72-9)}

\begin{tabular}{cccc}
\hline License No. & Issue date & Expiration date & DCSS \\
\hline SNM-2504 & $11 / 4 / 91$ & $11 / 30 / 11$ & MVDS \\
\hline
\end{tabular}

The Fort St. Vrain ISFSI employs the modular vault dry store (MVDS) system, designed by Foster Wheeler Energy Applications, Inc. (see Section 3.4). The ISFSI currently stores 1482 fuel elements.

\subsubsection{History}

The Fort St. Vrain site, owned and operated by the Public Service Company of Colorado (PSC), received its license to store fuel in an ISFSI on November 4, 1991. Fort St. Vrain was a hightemperature gas-cooled reactor (HTGC) that produced ${ }^{233} \mathrm{U}$ for future commercial reactor value. Fort St. Vrain was permanently shut down in August 1989. Fuel has been completely removed to the MVDS in order to begin decommissioning. Due to a past agreement to take ownership of the FSV fuel, the DOE plans on applying for a transfer of the ISFSI license from PSC to the DOE by the end of 1996.

\subsubsection{General Description of the Installation}

As shown in Figure 4.2-1, Fort St. Vrain is located near Platteville, Colorado. The location of the ISFSI in relation to the site is shown in Figure 4.2-2, and photographs of the ISFSI are shown in Figures 4.2-3 and 4.2-4. The MVDS ISFSI is enclosed within a fenced area located within the PSC owner-controlled area adjacent to the reactor protected area. The Fort St. Vrain ISFSI was designed as a stand-alone operation, although it currently relies on a portion of the plant's security system.

\subsubsection{Reference Documents}

U.S. Nuclear Regulatory Commission, Office of Nuclear Material Safety and Safeguards, "Environmental Assessment Related to the Construction and Operation of the Fort St. Vrain Independent Spent Fuel Storage Installation," February 1991. (Docket 72-9)

U.S. Nuclear Regulatory Commission, Office of Nuclear Material Safety and Safeguards, "Safety Evaluation Report for Public Service Company of Colorado's Safety Analysis Report for Fort St. Vrain Independent Spent Fuel Storage Installation," October 1991. (Docket 72-9)

Public Service Company of Colorado (PSC), "Safety Analysis Report - Fort St. Vrain Independent Spent Fuel Storage Installation," Rev. 6, 1995. (Docket 72-9) 


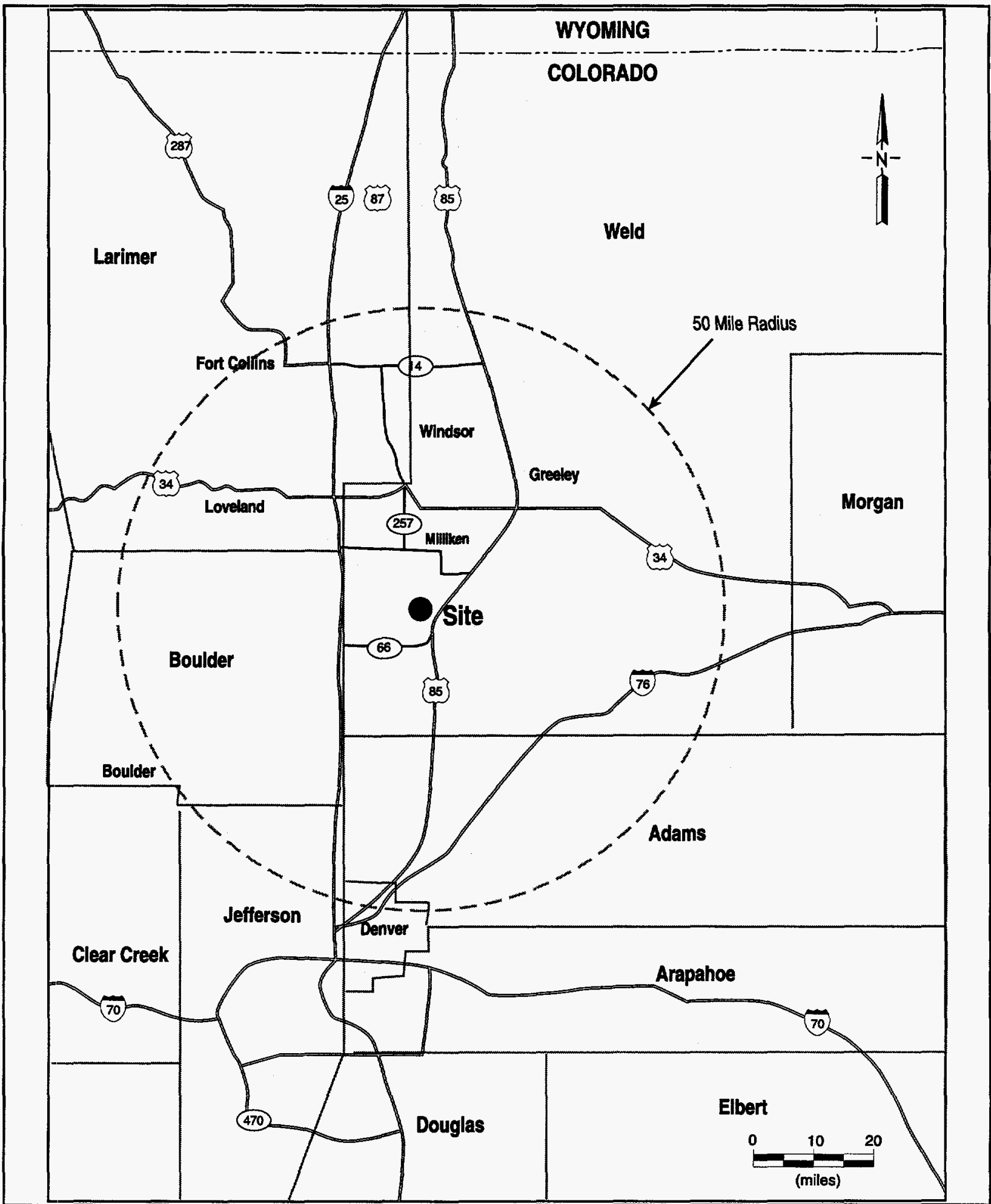

Figure 4.2-1 Fort St. Vrain Area Map 


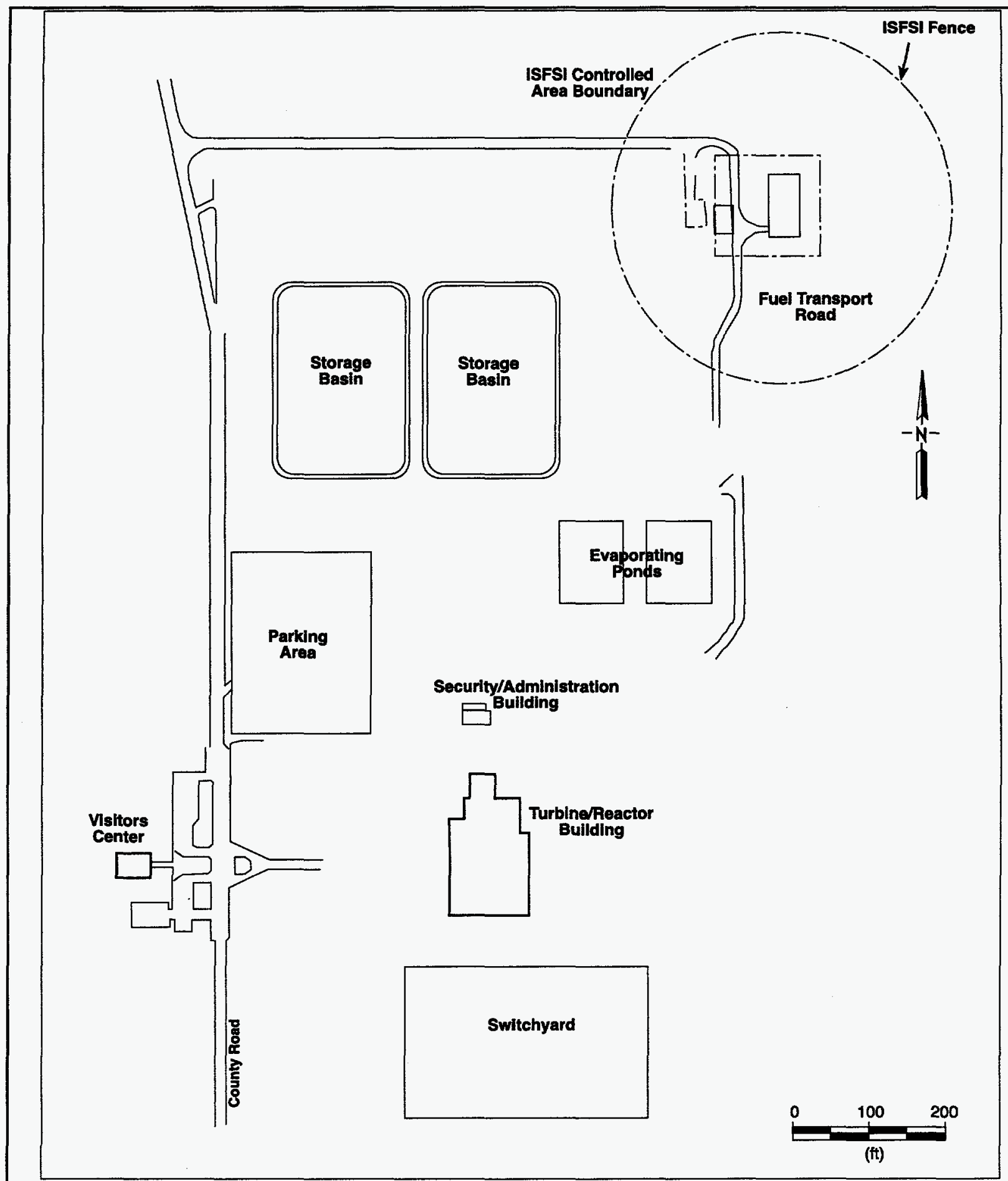

Figure 4.2-2 Fort St. Vrain Site Map 


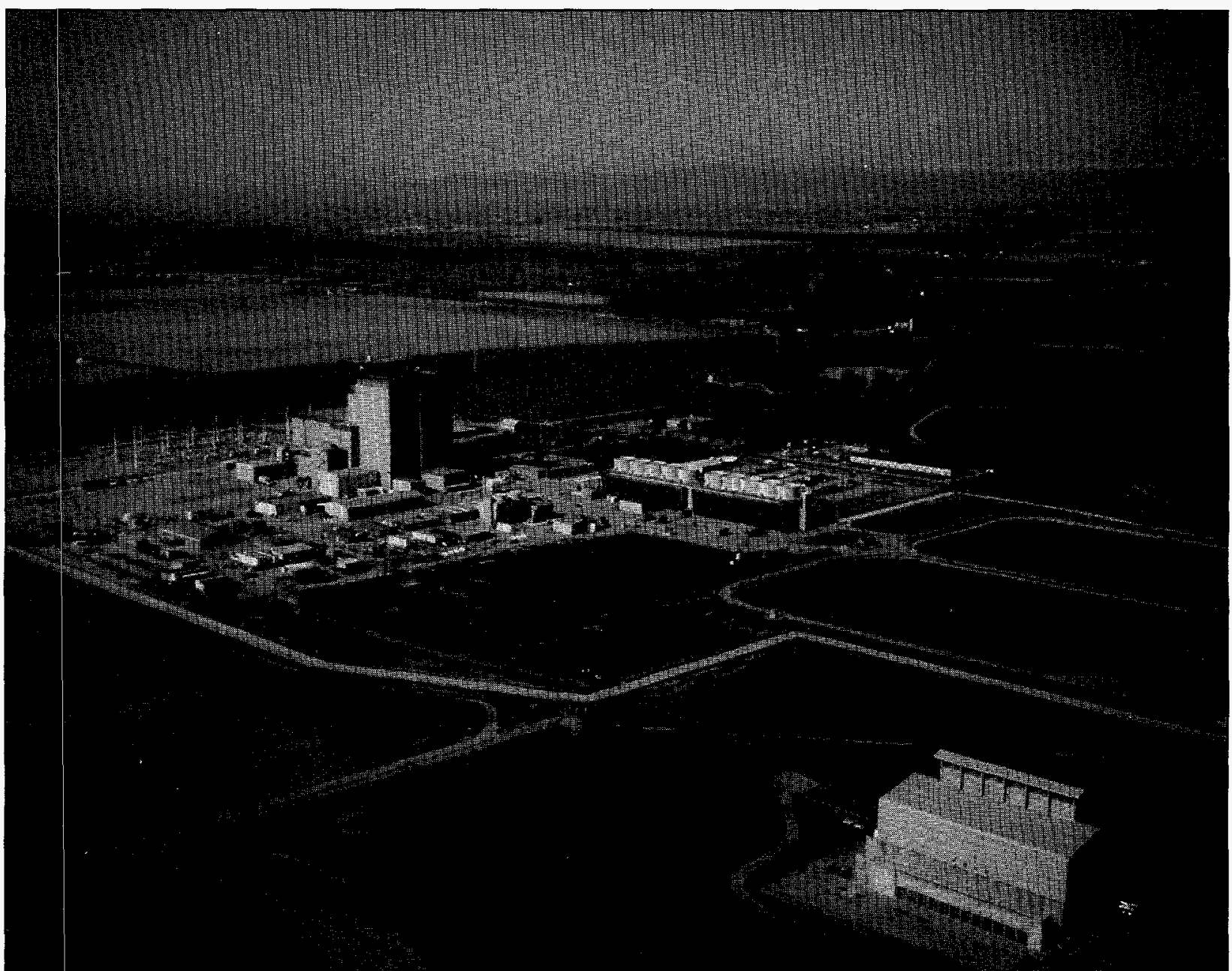

Figure 4.2-3 Photograph of the Fort St. Vrain ISFSI 


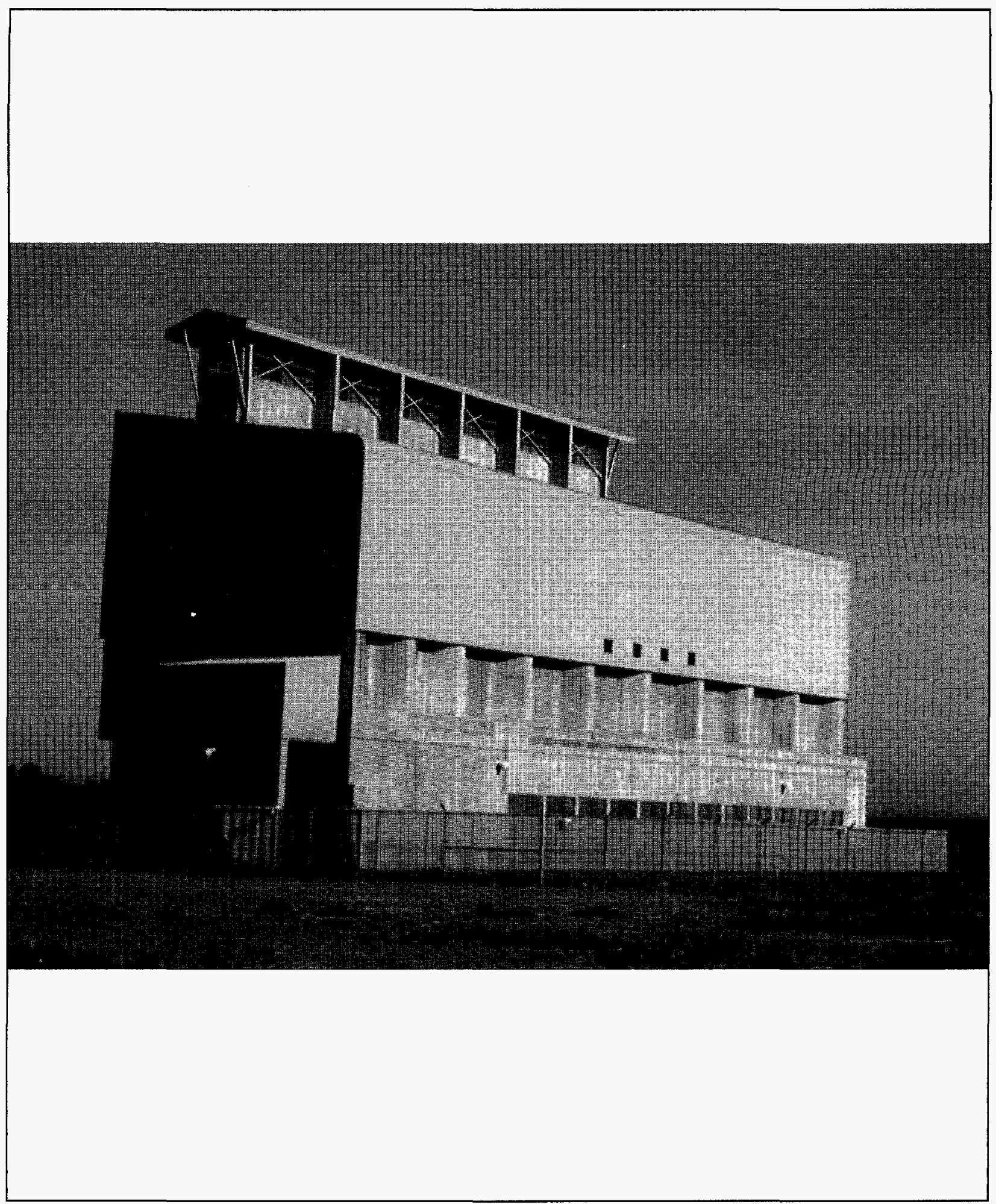

Figure 4.2-4 Photograph of the Fort St. Vrain ISFSI (Close-up) 


\subsection{H. B. Robinson ISFSI (Docket 72-3)}

\begin{tabular}{ccccc} 
License No. & Issue date & Expiration date & DCSS & Docket Number \\
\hline SNM-2502 & $8 / 13 / 86$ & $8 / 31 / 06$ & NUHOMS-7P & $72-3$ \\
\hline
\end{tabular}

The H.B. Robinson ISFSI employs the NUHOMS-7P, designed by VECTRA Technologies, Inc (see Section 3.9). It is licensed for a capacity of eight NUHOMS-7P modules holding a total of 56 SFAs. The ISFSI currently has eight modules loaded.

\subsubsection{History}

The H. B. Robinson Unit 2, owned and operated by Carolina Power \& Light Company (CP\&L), received its license to store fuel in an ISFSI on August 13, 1986. In 1984, in response to the U.S. DOE's Solicitation for Cooperative Agreement Program, CP\&L implemented a Demonstration Program at H.B. Robinson. CP\&L entered into an agreement with the DOE to demonstrate this new storage technology in which the stainless steel canisters are stored horizontally in reinforced concrete modules (NUHOMS). The Electric Power Research Institute (EPRI) and the DOE, as authorized by Section 218 of NWPA (see Section 1.2.2), provided financial and programmatic support to the program.

\subsubsection{General Description of the Installation}

As shown in Figure 4.3-1, H. B. Robinson Unit 2 is located in the northwest portion of Darlington County, South Carolina. The location of the ISFSI in relation to the site is shown in Figure 4.3-2 and a photograph of the ISFSI is shown in Figure 4.3-3. The ISFSI is located $183 \mathrm{~m}(600 \mathrm{ft})$ west of Unit 2.

\subsubsection{Reference Documents}

U.S. Nuclear Regulatory Commission, Office of Nuclear Material Safety and Safeguards, "Environmental Assessment Related to the Construction and Operation of the H. B. Robinson Independent Spent Fuel Storage Installation," Carolina Power and Light Company, March 1986. (Docket 72-3)

U.S. Nuclear Regulatory Commission, Office of Nuclear Material Safety and Safeguards, "Safety Evaluation Report of H. B. Robinson Steam Electric Plant Unit No. 2 Independent Spent Fuel Storage Installation," June 1986. (Docket 72-3)

Carolina Power and Light Company, "Independent Spent Fuel Storage Installation Safety Analysis Report for H.B. Robinson Steam Electric Plant," Rev. 12, March 1996. (Docket 72-3) 


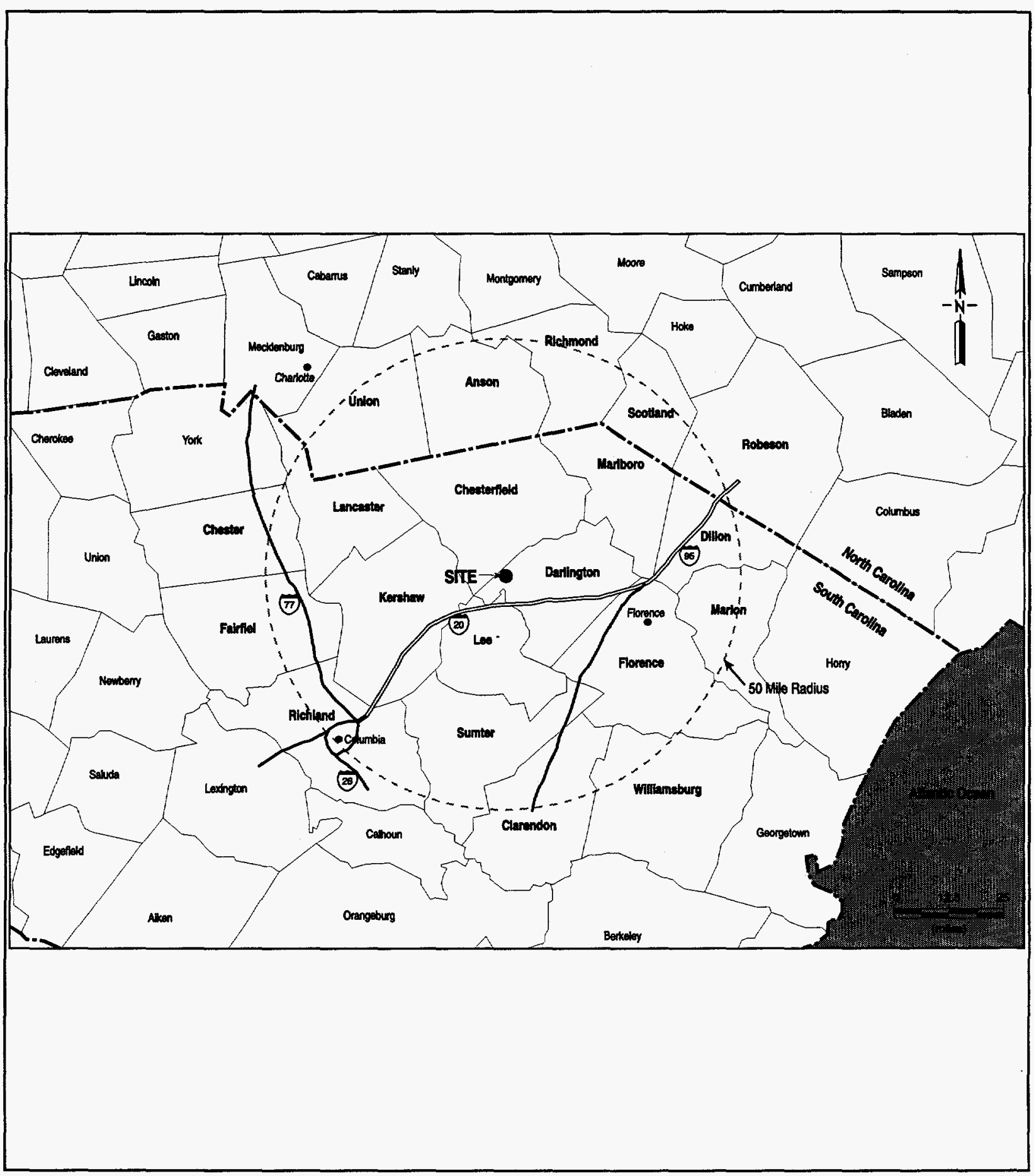

Figure 4.3-1 H.B. Robinson Unit 2 Area Map 


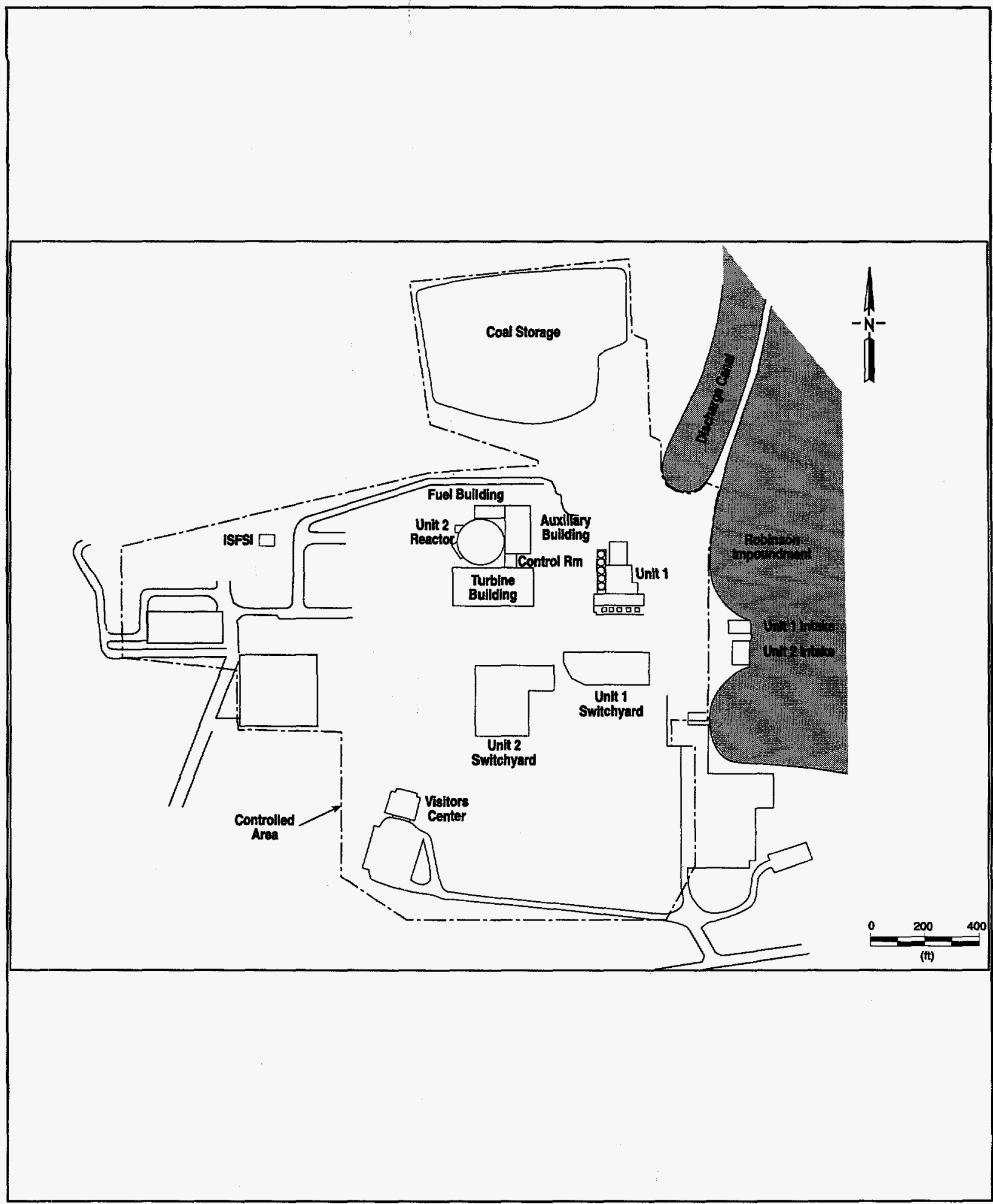

Figure 4.3-2 H.B. Robinson Unit 2 Site Map 


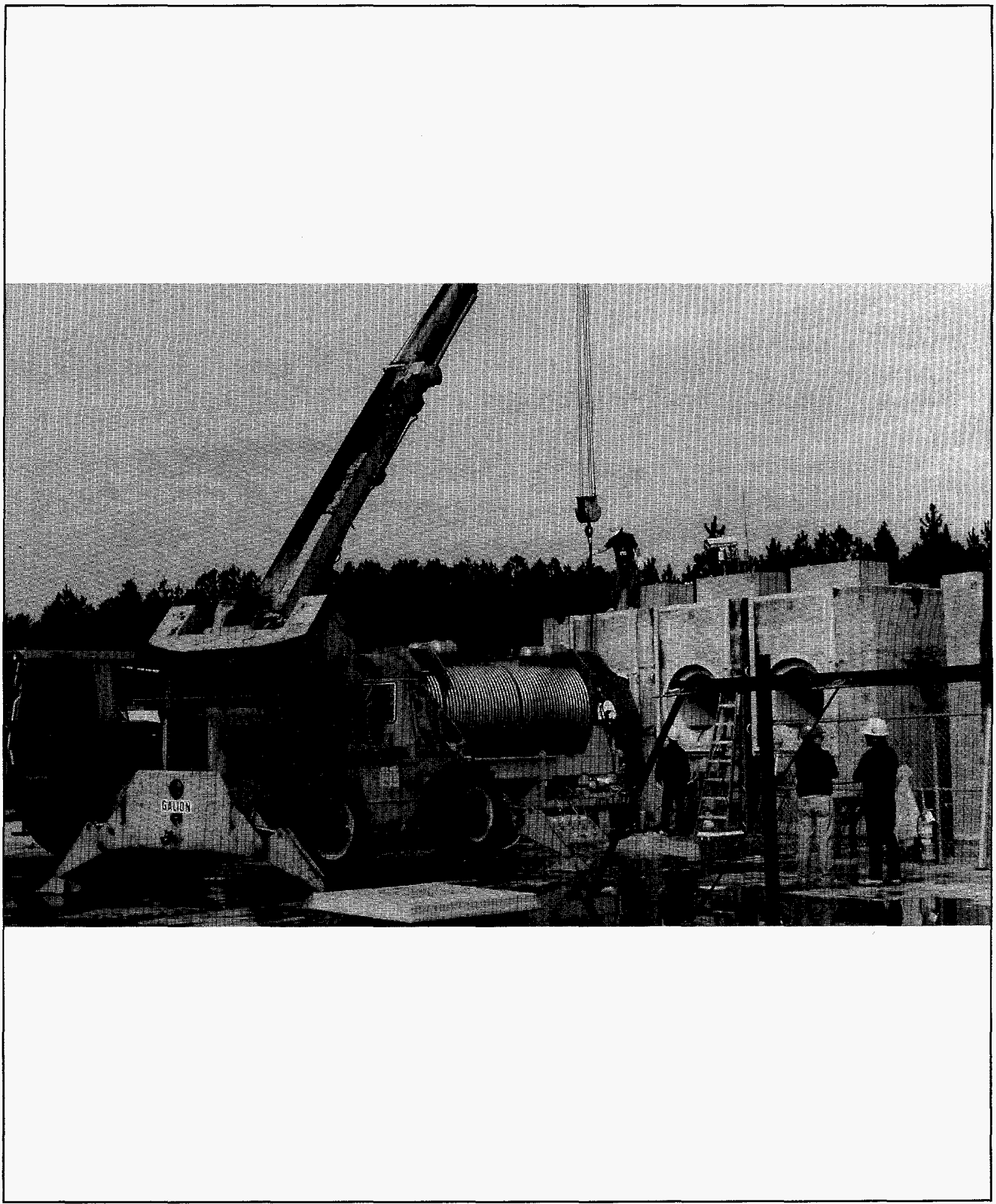

Figure 4.3-3 Photograph of the H.B.Robinson ISFSI During Loading 


\subsection{Oconee ISFSI (Docket 72-4)}

\begin{tabular}{cccc}
\hline License No. & Issue date & Expiration date & DCSS \\
\hline SNM-2503 & $1 / 29 / 90$ & $1 / 31 / 10$ & NUHOMS-24P \\
\hline
\end{tabular}

The Oconee ISFSI employs the NUHOMS-24P, designed by VECTRA Technologies, Inc (see Section 3.10). It is licensed for a capacity of 88 NUHOMS modules holding a total of 2112 SFAs, and provides storage for Units $1,2, \& 3$. . The ISFSI currently has 34 modules loaded.

\subsubsection{History}

The Oconee Nuclear Station, owned and operated by the Duke Power Company, received its license to store fuel in an ISFSI on January 29, 1990.

\subsubsection{General Description of the Installation}

As shown in Figure 4.4-1, the Oconee Nuclear Station is located in eastern Oconee County, South Carolina. The location of the ISFSI in relation to the site is shown in Figure 4.4-2. The ISFSI is located outside the protected area and within the owner controlled area $30 \mathrm{~m}(100 \mathrm{ft})$ west of the Oconee cooling towers.

\subsubsection{Reference Documents}

U.S. Nuclear Regulatory Commission, Office of Nuclear Material Safety and Safeguards, "Environmental Assessment Related to the Construction and Operation of the Oconee Nuclear Station Independent Spent Fuel Storage Installation," Duke Power Company, October 1988. (Docket 72-4)

U.S. Nuclear Regulatory Commission, Office of Nuclear Material Safety and Safeguards, "Safety Evaluation Report of the Oconee Nuclear Station Independent Spent Fuel Storage Installation," October 1989. (Docket 72-4)

NUTECH Engineers, Inc., "Topical Report for the NUTECH Horizontal Modular Storage System for Irradiated Nuclear Fuel, NUHOMS-24P" (NUH-002), Rev. 5, December 1995. (Docket 72-1004) 


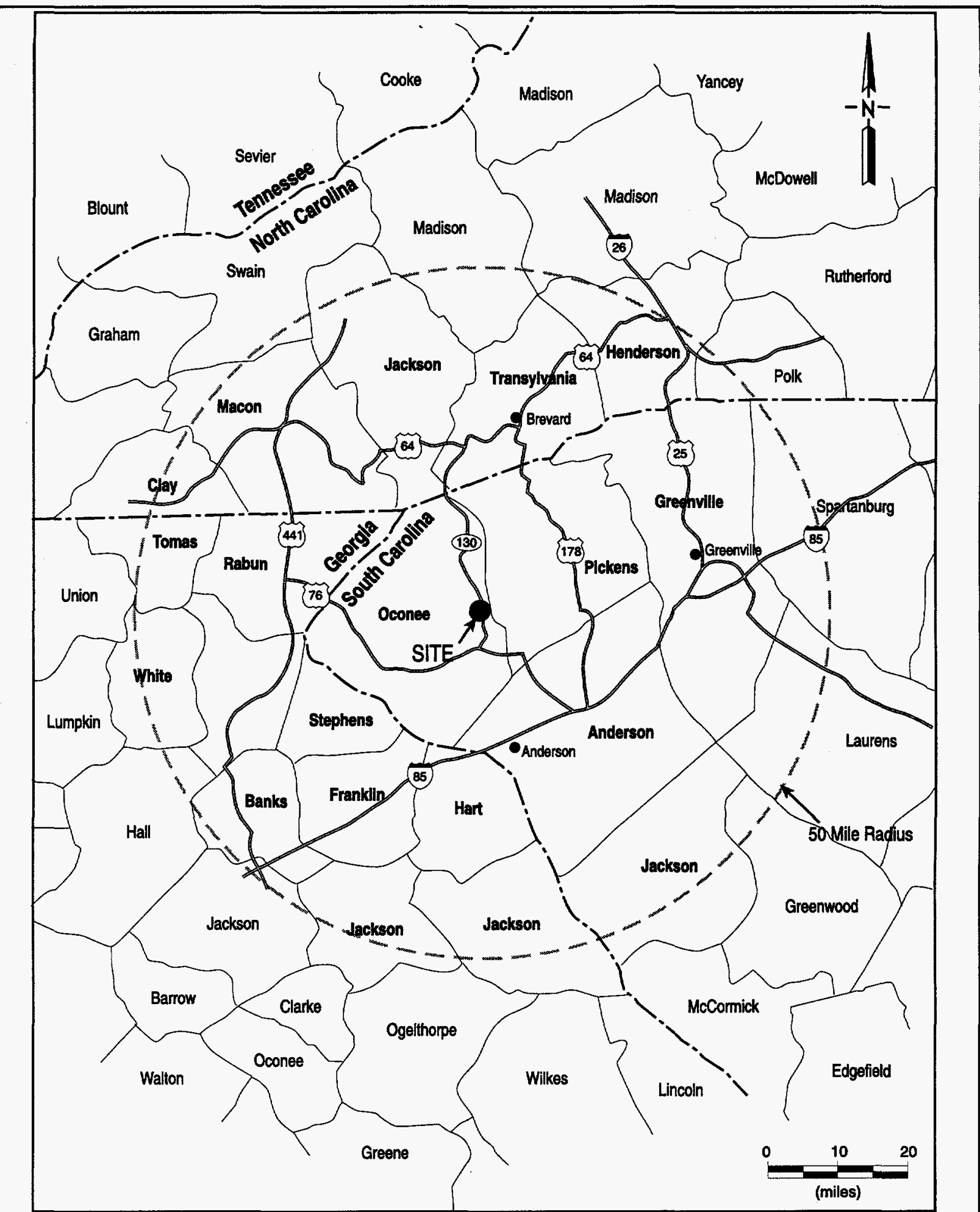

Figure 4.4-1 Oconee Nuclear Station Area Map 


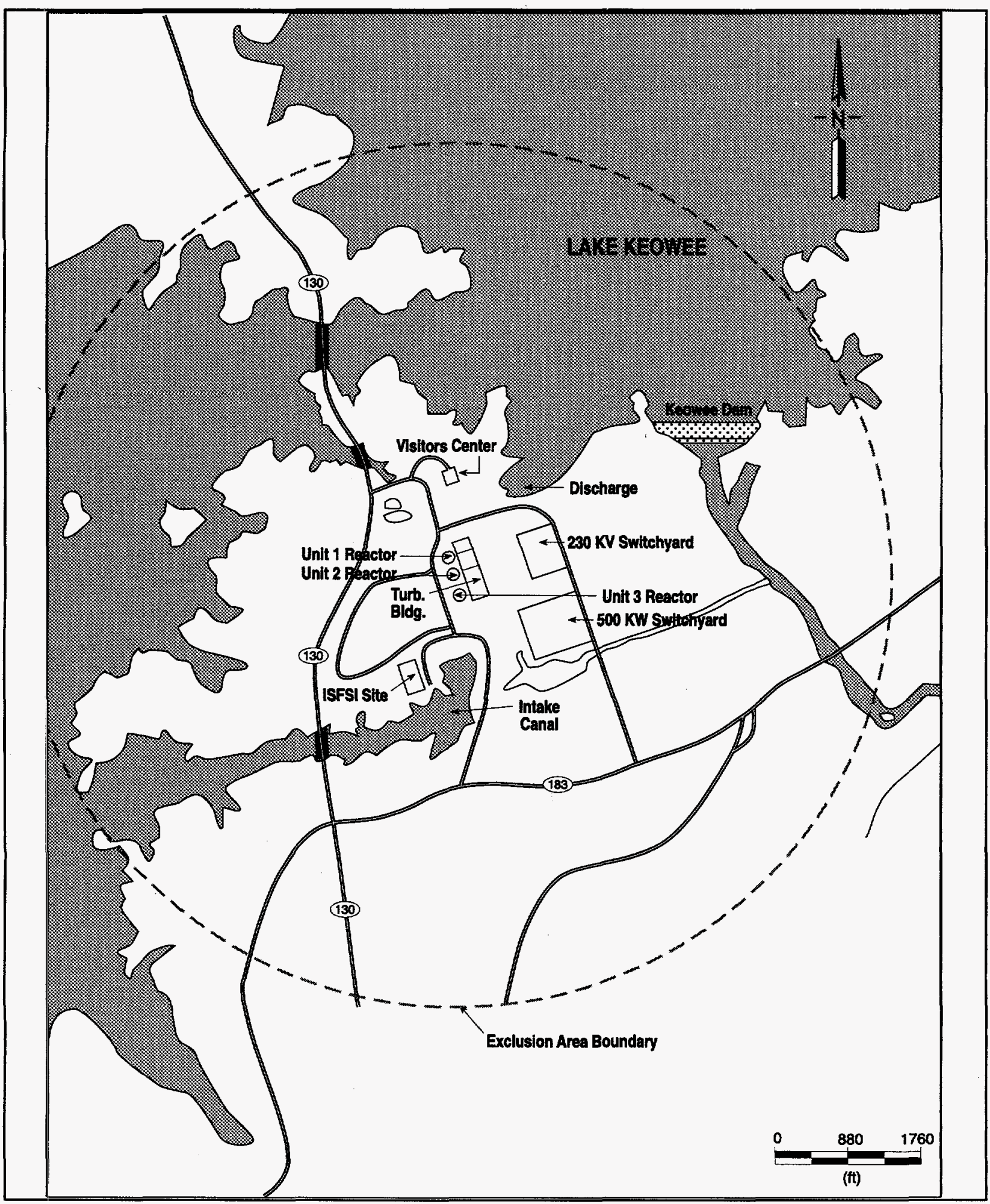

Figure 4.4-2 Oconee Nuclear Station Site Map 


\subsection{Prairie Island ISFSI (Docket 72-10)}

\begin{tabular}{lccc}
\hline License No. & Issue date & Expiration date & DCSS \\
\hline SNM-2506 & $10 / 19 / 93$ & $10 / 31 / 13$ & TN-40 \\
\hline
\end{tabular}

The Prairie Island ISFSI employs the TN-40, designed by Transnuclear, Inc (see Section 3.12). It is licensed for a capacity of 48 TN-40 casks holding a total of 1920 SFAs. The ISFSI currently has five casks loaded.

\subsubsection{History}

The Prairie Island Nuclear Power Plant, owned and operated by Northern States Power Company (NSP), received its license to store fuel in an ISFSI on October 19, 1993. The fully implemented ISFSI will consist of two reinforced concrete pads that will hold 48 casks. An earlier decision by the Minnesota Public Utilities Commission (MPUC) to allow 17 casks for above-ground spent fuel storage at the Prairie Island site was granted in June 1991. In March 1993, the Minnesota Appeals Court found that NSP needed the Minnesota legislature's approval before using dry cask storage to supplement diminishing space in the plant's SFP. A State law required the State legislature's approval for "permanent" spent fuel storage within Minnesota. The appeals court concluded, and the Minnesota Supreme Court agreed, that NSP's ISFSI constituted "permanent" storage because of the lack of a Federal geologic repository.

A State law was passed in May 1994 which allowed NSP to immediately load five casks. The bill allowed four additional casks to be loaded by December 31, 1996, if NSP filed a license application for an alternate storage site located off the island, and if NSP possessed alternate energy facilities. Under the law, eight more casks can be loaded if NSP meets further alternate energy requirements. In order to continue cask loading, NSP applied for a license in August 1996, to construct and operate an ISFSI at an away-from-reactor site located in Goodhue County, Minnesota. The application is currently under NRC review.

\subsubsection{General Description of the Installation}

As shown in Figure 4.5-1, the Prairie Island nuclear generating station is located in Goodhue County, Minnesota. The location of the ISFSI in relation to the site is shown in Figure 4.5-2, and photographs of the ISFSI are shown in Figures 4.5-3 and 4.5-4. The ISFSI is located approximately $500 \mathrm{~m}$ (1500

$\mathrm{ft}$ ) southeast of the Prairie Island Units 1 and 2 reactor buildings and within the site boundary and exclusion area of the Prairie Island site. 


\subsubsection{Reference Documents}

U.S. Nuclear Regulatory Commission, Office of Nuclear Material Safety and Safeguards, "Environmental Assessment Related to Construction and Operation of the Prairie Island Independent Spent Fuel Storage Installation," July 1992. (Docket 72-10)

U.S. Nuclear Regulatory Commission, Office of Nuclear Material Safety and Safeguards, "Safety Evaluation Report for the Prairie Island Independent Spent Fuel Storage Installation," July 1993. (Docket 72-10)

Northern States Power Company, "Prairie Island Independent Spent Fuel Storage Installation Technical Specifications and Safety Analysis Report," Rev. 4, October 1995. (Docket 72-10)

Midwestern Office, The Council of State Governments, Midwestern High-Level Radioactive Waste Transportation Project, "Report on Interim Storage of Spent Nuclear Fuel: Supplement," DOE/RW/00286-6, Rev. 1, January 1995. 


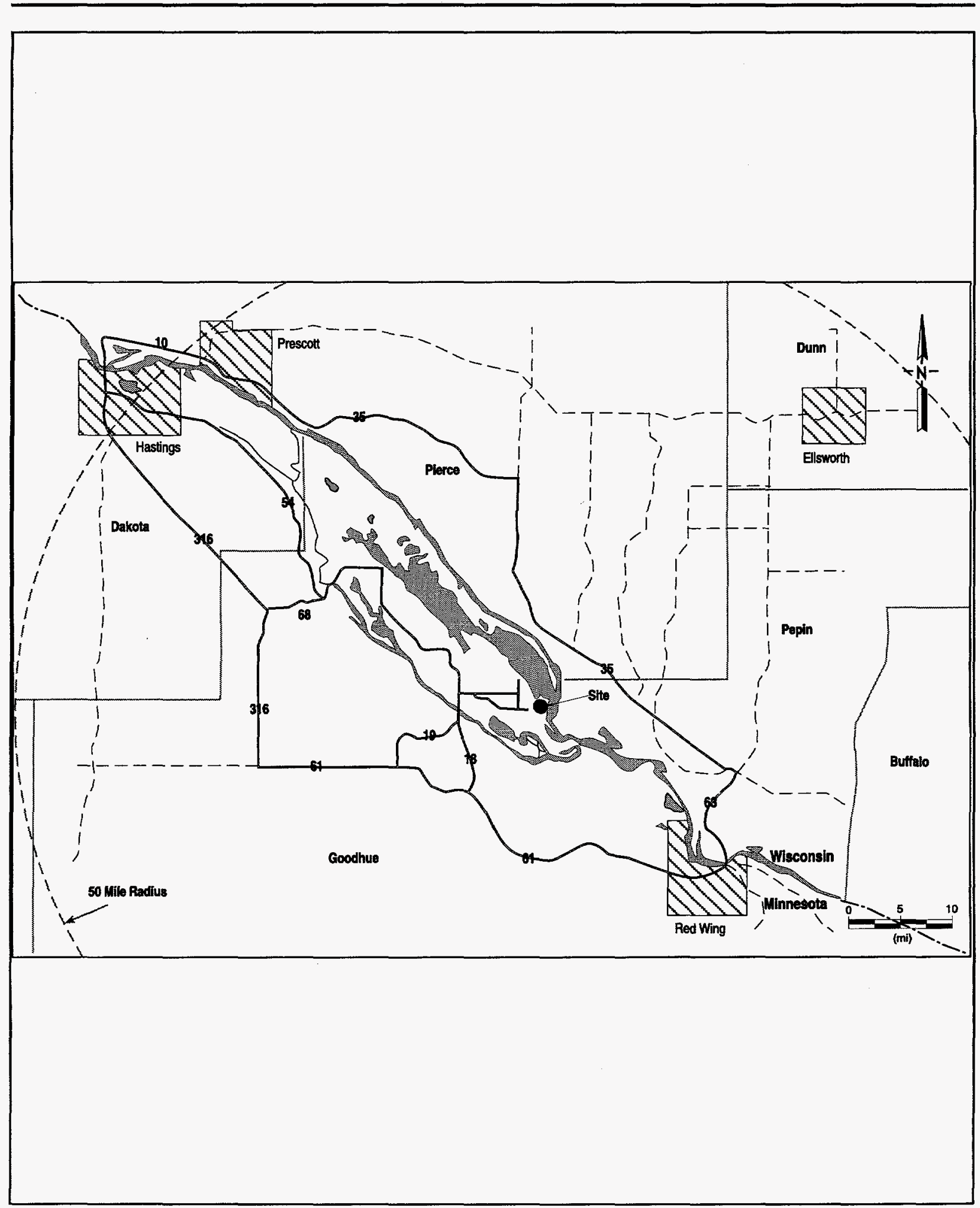

Figure 4.5-1 Prairie Island Nuclear Generating Station Area Map 


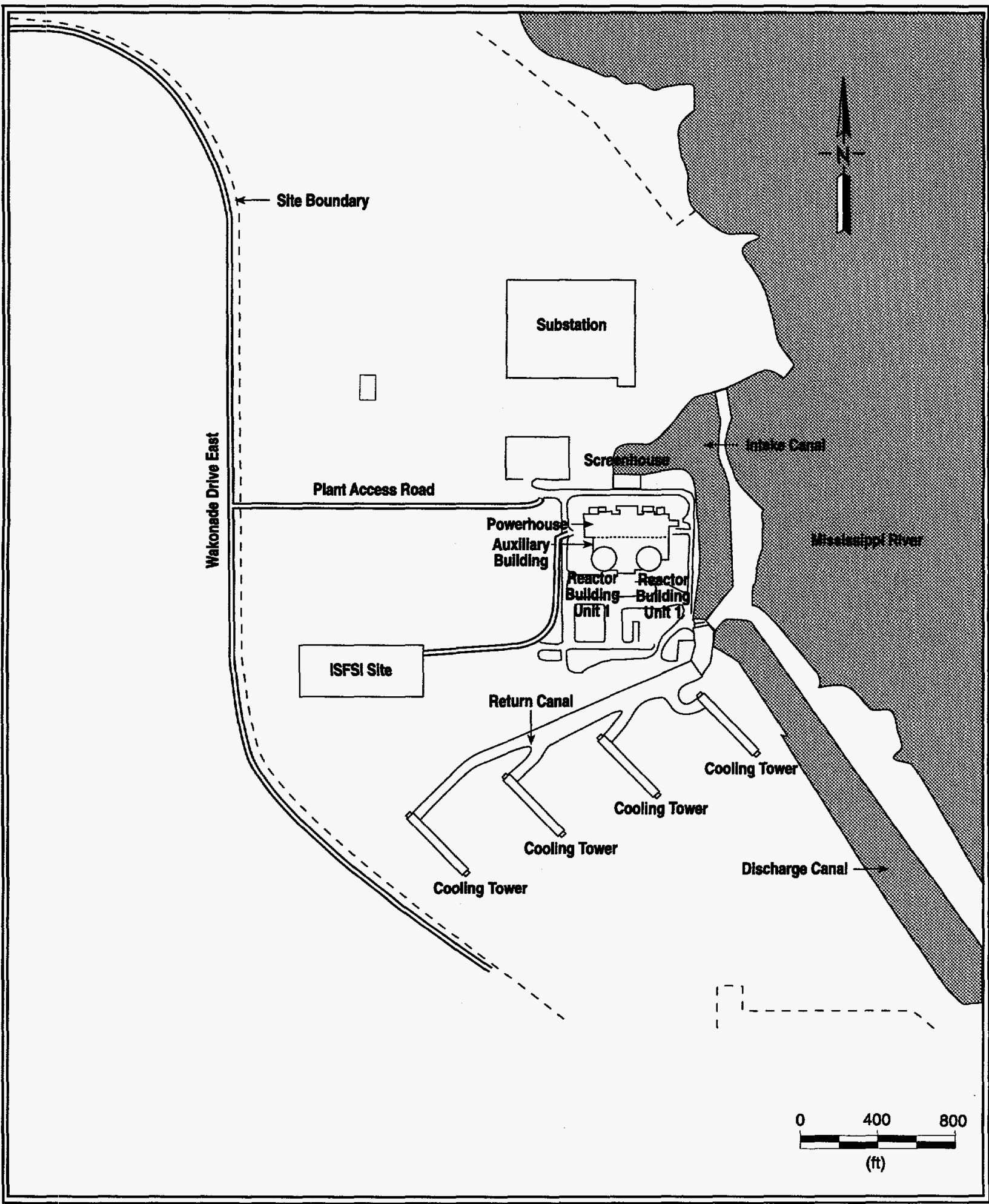

Figure 4.5-2 Prairie Island Nuclear Generating Station Site Map 


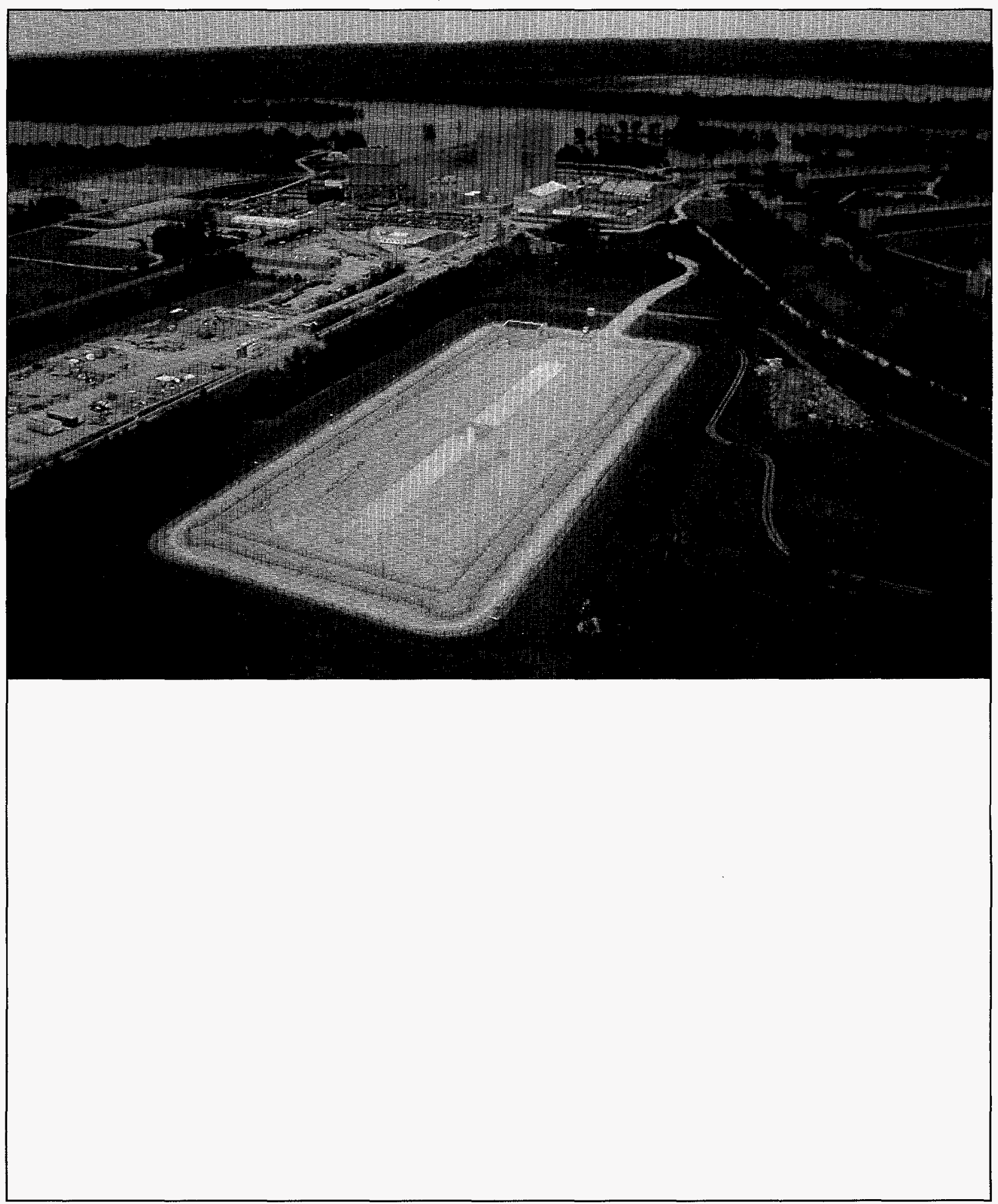

Figure 4.5-3 Photograph of the Prairie Island ISFSI 


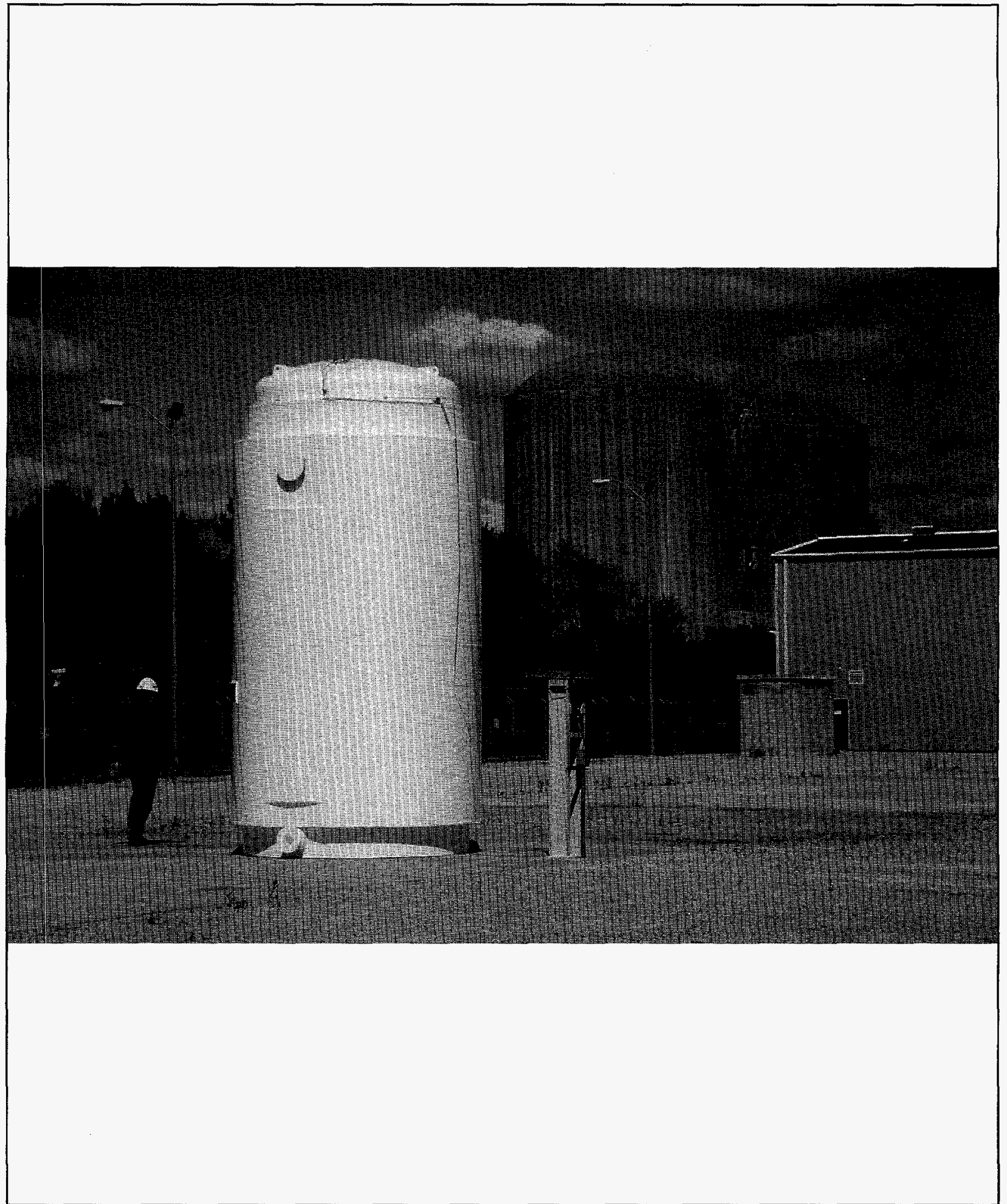

Figure 4.5-4 Photograph of Prairie Island ISFSI (Close-up) 


\subsection{Surry ISFSI (Docket 72-2)}

\begin{tabular}{cccc}
\hline License No. & Issue date & Expiration date & DCSS \\
\hline SNM-2502 & $8 / 13 / 86$ & $8 / 31 / 06$ & Castor V/21 \\
Amendment 3 & $2 / 15 / 90$ & $2 / 15 / 10$ & MC-10 \\
Amendment 4 & $5 / 16 / 90$ & $5 / 16 / 10$ & NAC-128 S/T \\
Amendment 7 & $6 / 29 / 94$ & $6 / 29 / 14$ & Castor X/33 \\
\hline
\end{tabular}

The Surry ISFSI employs the Castor V/21 and Castor X/33 designed by General Nuclear Systems, the MC-10 designed by Westinghouse Corporation, and NAC-I28 S/T designed by Nuclear Assurance Corporation (see Sections 3.1, 3.2, 3.3 and 3.5, respectively). The ISFSI is licensed to hold up to 1,764 SFAs. The ISFSI currently has 29 casks loaded.

\subsubsection{History}

Surry Power Station, owned and operated by the Virginia Electric \& Power Company (VEPCO), received its license to store fuel in an ISFSI on August 13, 1986. Surry was the first utility in the United States to receive a license to store spent nuclear fuel under the provisions of 10 CFR Part 72. In 1983 in response to the U.S. DOE's Solicitation for Cooperative Agreement Program, VEPCO implemented a program involving cask performance testing at a Federal site in support of a licensed demonstration at the Surry Power Station. A cooperative agreement was signed by VEPCO and DOE in March 1984. VEPCO also signed a separate agreement with EPRI as part of the program. Cask testing in support of the Surry ISFSI was conducted at the Idaho National Engineering Laboratory (INEL) Test Area North (TAN) by DOE, EG\&G Idaho, and the Pacific Northwest Laboratory. The VEPCO portion of the cooperative agreement involved the selection and purchase of casks (Castor and MC-10) to be tested at TAN, transfer of SFAs to TAN, and the design, licensing, and operation of a dry cask storage ISFSI at Surry.

\subsubsection{General Description of the Installation}

As shown in Figure 4.6-1, the Surry Power Station is located in southeast Virginia on the James River in Surry County. The location of the ISFSI in relation to the site is shown in Figure 4.6-2, and photographs of the ISFSI are shown in Figures 4.6-3 and 4.6-4. The ISFSI is located approximately $1000 \mathrm{~m}(3300 \mathrm{ft})$ southeast of the Surry Power Station Units 1 and 2 reactor buildings and within the boundaries of the Surry site. The fully implemented ISFSI will consist of three reinforced-concrete pads, built on an as-needed basis, on which the dry storage casks are placed. 


\subsubsection{Reference Documents}

U.S. Nuclear Regulatory Commission, Office of Nuclear Material Safety and Safeguards, "Environmental Assessment Related to the Construction and Operation of the Surry Dry Cask Independent Spent Fuel Storage Installation," Virginia Electric \& Power Company, April 1985. (Docket 72-2)

U.S. Nuclear Regulatory Commission, Office of Nuclear Material Safety and Safeguards, "Safety Evaluation Report of Surry Dry Cask Independent Spent Fuel Storage Installation," May 1986. (Docket 72-2)

Virginia Electric \& Power Company, "Safety Analysis Report for Surry Power Station Dry Cask Independent Spent Fuel Storage Installation," Rev. 7, 1994. (Docket 72-2) 


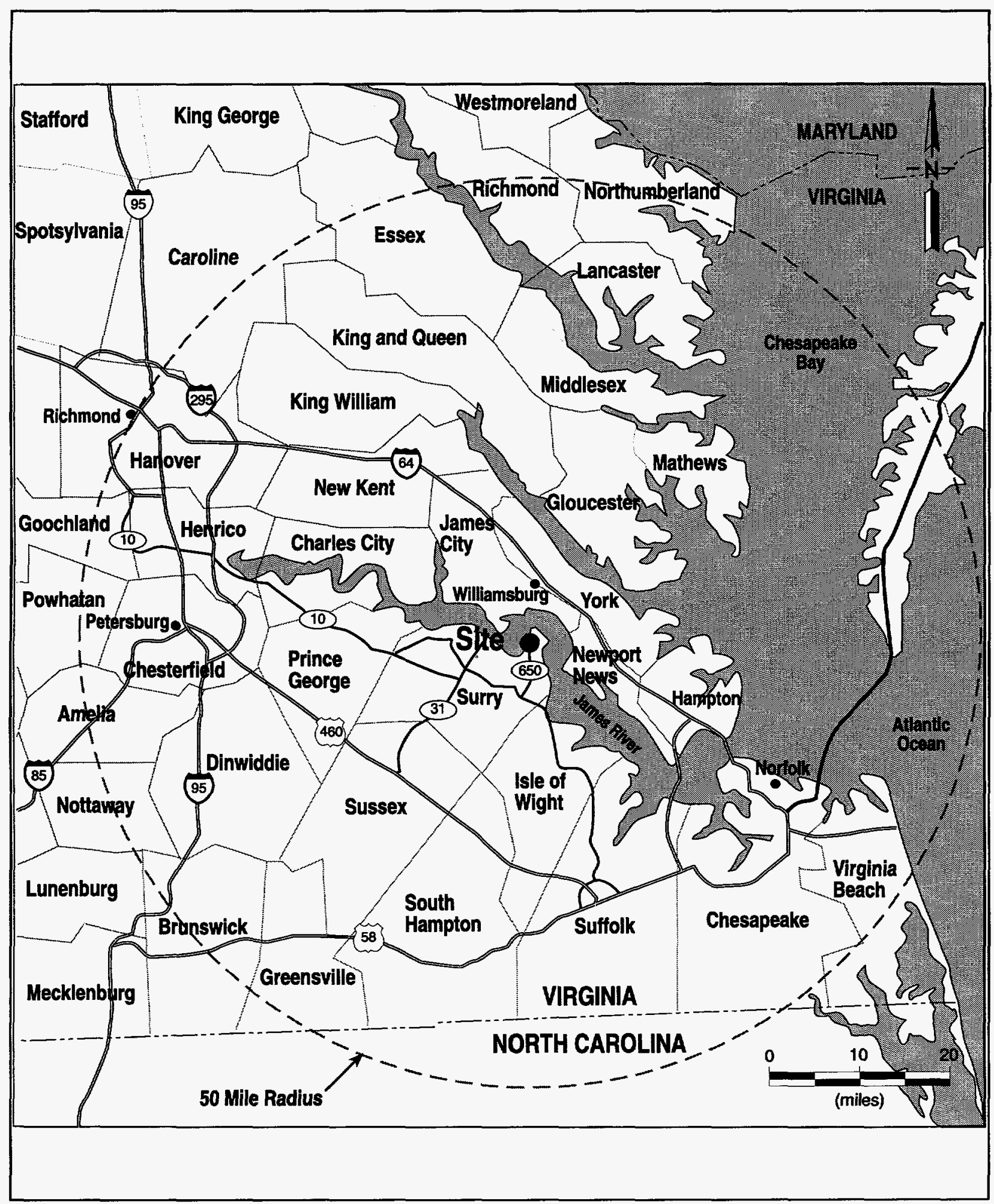

Figure 4.6-1 Surry Power Station Area Map 


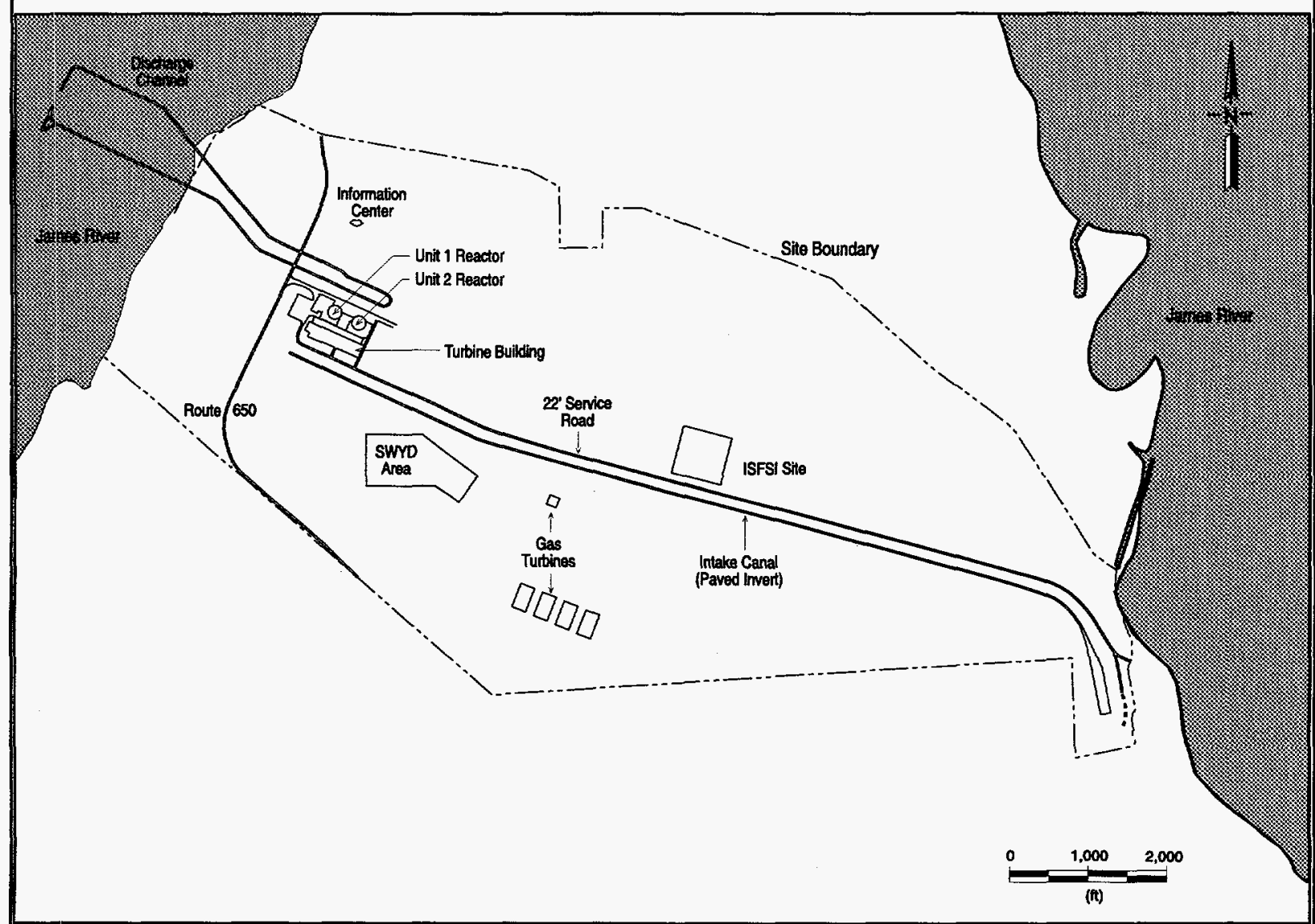

Figure 4.6-2 Surry Power Station Site Map 


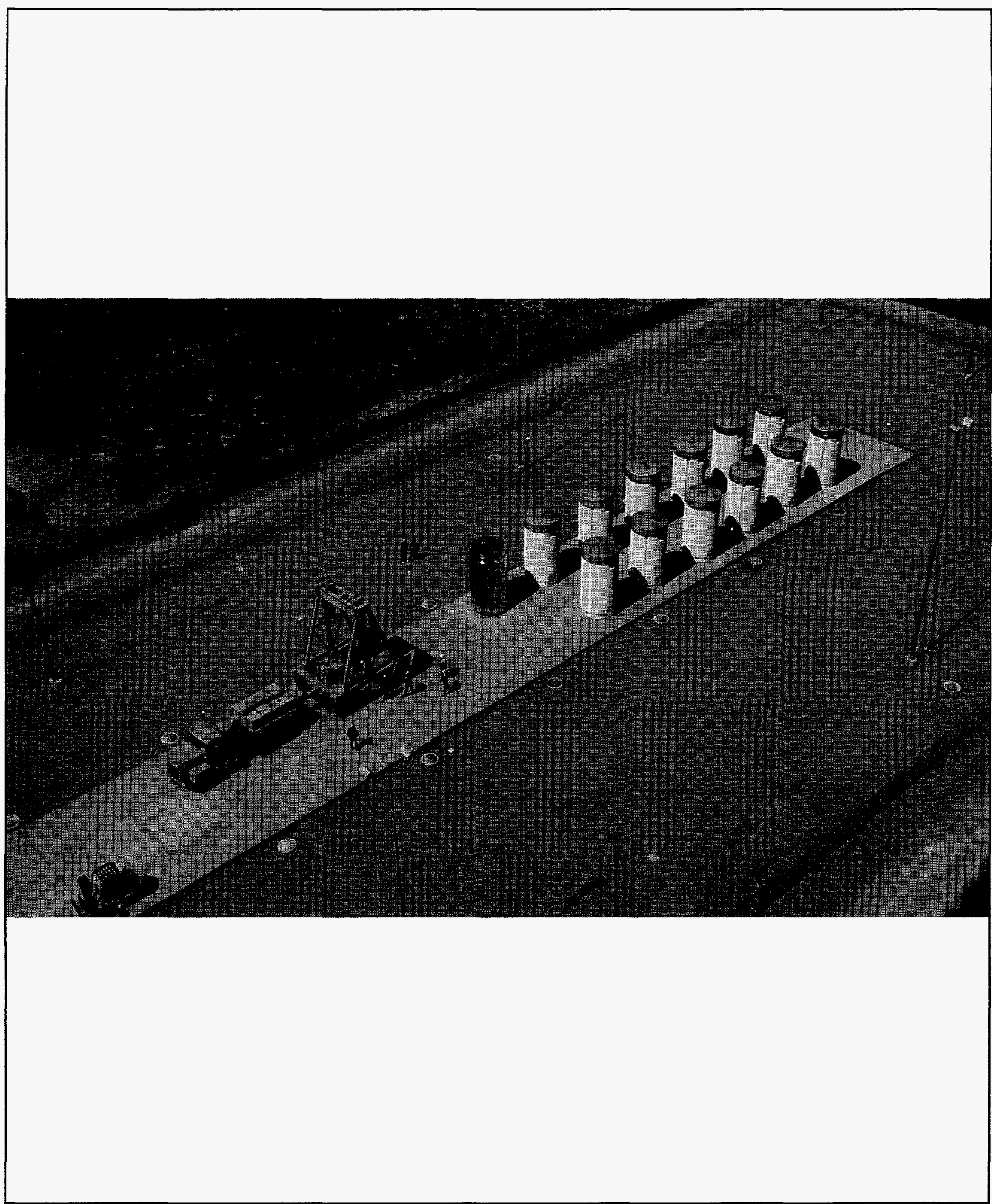

Figure 4.6-3 Photograph of the Surry ISFSI 


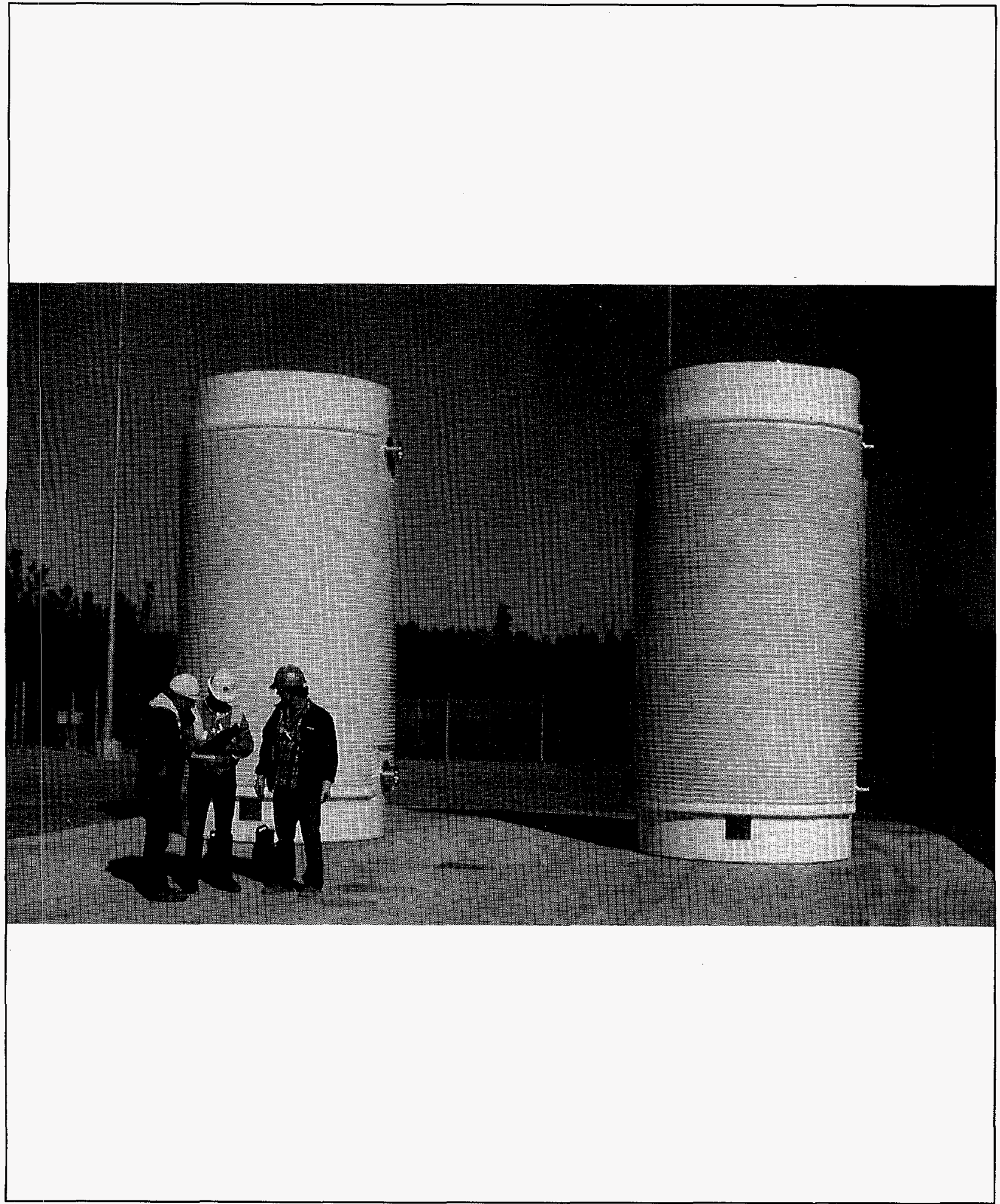

Figure 4.64 Photograph of the Surry ISFSI (Close-up) 


\section{GENERAL LICENSE ISFSIS}

This section contains information on all ISFSI sites currently storing fuel under the general license authorized by 10 CFR Part 72, Subpart K. As discussed in Section 2.2, all power reactor licensees have been given a general license to store fuel in a DCSS that has received a certificate of compliance from the NRC. Details of the DCSS used for each ISFSI are described in Section 3. General license ISFSIs storing spent fuel are summarized in Table 5.1.

Table 5.1 General License ISFSI Sites Storing Spent Fuel

\begin{tabular}{|c|c|c|c|c|}
\hline ISFSI & Operator & $\begin{array}{c}\text { First Loading } \\
\text { Date }\end{array}$ & DCSS & $\begin{array}{c}\text { No. of Casks } \\
\text { (Sept. 1996) }\end{array}$ \\
\hline $\begin{array}{c}\text { Arkansas Nuclear } \\
\text { One }\end{array}$ & Entergy Operations & & VSC-24 & $0^{*}$ \\
\hline Davis-Besse & Toledo Edison Company & $01 / 96$ & $\begin{array}{c}\text { Standardized } \\
\text { NUHOMS-24P }\end{array}$ & 3 \\
\hline Palisades & Consumers Power Company & $05 / 93$ & VSC-24 & 7 \\
\hline Point Beach & $\begin{array}{c}\text { Wisconsin Electric Power } \\
\text { Company }\end{array}$ & $12 / 95$ & VSC-24 & 2 \\
\hline
\end{tabular}

*Arkansas Nuclear One awaiting to load first cask once NRC Bulletin 96-04 (see Section 5.4) is resolved. 


\subsection{Arkansas Nuclear One ISFSI (Docket 72-13)}

\begin{tabular}{cccc}
\hline License No. & DCSS & COC Issue Date & COC Expiration Date \\
\hline General & VSC-24 & $11 / 4 / 91$ & $11 / 30 / 11$ \\
\hline
\end{tabular}

The Arkansas ISFSI employs the VSC-24, designed by Sierra Nuclear Corporation (see Section 3.14). It currently does not have any casks loaded.

\subsubsection{History}

The Arkansas Nuclear One Power Plant, owned and operated by Entergy Operations, plans to load fuel in the VSC-24 by the end of 1996, upon resolution of NRC Bulletin 96-04 (see Section 5.4).

\subsubsection{General Description of the Installation}

The Arkansas Nuclear One Power Plant is located in Russellville, Arkansas. The ISFSI is within the site boundary of the plant.

\subsubsection{Reference Documents}

Pacific Sierra Nuclear, "Topical Report on the Ventilated Storage Cask System for Irradiated Fuel," Rev. 2," Volumes 1 and 2, July 1990. (Docket 72-1007)

U.S. Nuclear Regulatory Commission, Office of Nuclear Material Safety and Safeguards, "Safety Evaluation Report for Pacific Sierra Nuclear Topical Report on the Ventilated Storage Cask System for Irradiated Fuel, Revision 2," March, 1991. (Docket 72-1007)

U.S. Nuclear Regulatory Commission, NRC Bulletin 96-04: "Chemical, Galvanic, or Other Reactions in Spent Fuel Storage and Transportation Casks," July 5, 1996. 


\subsection{Davis-Besse ISFSI (Docket 72-14)}

\begin{tabular}{cccccc}
\hline License No. & DCSS & COC Issue Date & COC Expiration Date & Docket Number \\
\hline \multirow{2}{*}{ General } & $\begin{array}{c}\text { Standardized } \\
\text { NUHOMS. } \\
\text { 24P }\end{array}$ & $01 / 23 / 95$ & $01 / 3 / 95$ & $72-14$ \\
& & & & \\
\hline
\end{tabular}

The Davis-Besse ISFSI employs the Standardized NUHOMS-24P, designed by VECTRA Technologies, Inc. (See Section 3.11). The ISFSI currently has three loaded modules.

\subsubsection{History}

The Davis-Besse Nuclear Power Plant, owned and operated by Toledo Edison Company, loaded its first HSM in January 1996. Davis-Besse was delayed in loading its first modules due to a challenge to 10 CFR 72.82(e) which requires submittal of pre-operational testing results 30 days prior to loading of the first module. Davis-Besse was ultimately granted an exemption under 10 CFR 72.7, and was allowed to submit the results in a shorter time before fuel loading. In addition, a problem with the fabrication of the NUHOMS DSC added to the delay.

\subsubsection{General Description of the Installation}

The Davis-Besse nuclear power plant is located in Oak Harbor, Ohio. The ISFSI is within the site boundary of the plant.

\subsubsection{Reference Documents}

Pacific Nuclear Fuel Services, Inc., "Safety Analysis Report for the Standardized NUHOMS Horizontal Modular Storage System for Irradiated Nuclear Fuel" (NUH-003, Rev 4A), June 1996. (Docket 72-1004)

U.S. Nuclear Regulatory Commission, Office of Nuclear Material Safety and Safeguards, "Safety Evaluation Report of Pacific Nuclear Fuel Services Safety Analysis Report for the Standardized NUHOMS Horizontal Modular Storage System for Irradiated Nuclear Fuel, (NUH-003, Rev 2)," November 1993. (Docket 72-1004)

Federal Register, Vol. 61, No.3, January 4, 1996, "Toledo Edison Co., Davis-Besse Nuclear Power Station, Independent Spent Fuel Storage Installation; Exemption," p. 356. 


\subsection{Palisades ISFSI (Docket 72-7)}

\begin{tabular}{cccc}
\hline License No. & DCSS & COC Issue Date & COC Expiration Date \\
\hline General & VSC-24 & $11 / 4 / 91$ & $11 / 30 / 11$ \\
\hline
\end{tabular}

The Palisades ISFSI employs the VSC-24, designed by Sierra Nuclear Corporation. The ISFSI currently has seven loaded casks.

\subsubsection{History}

The Palisades Nuclear Power Plant, owned and operated by the Consumers Power Company of Michigan (CPC), loaded its first cask in May 1993. Palisades was the first utility to utilize the revised 10 CFR Part 72 that authorized the general license.

In April 1993, the general license approval was challenged by the Michigan Attorney General and Lake Michigan Federation citizen organization on the grounds that the licensing process should have entailed a full EIS rather than the less-detailed EA. The U.S. District Court for Western Michigan denied the request to prevent cask loading, and the denial was ultimately upheld by the U.S. Supreme Court.

\subsubsection{General Description of the Installation}

As shown in Figure 5.3-1, the Palisades nuclear power plant is located on the eastern shore of Lake Michigan in Van Buren County, Michigan. The location of the ISFSI in relation to the site is shown in Figure 5.3-2 and a photograph of the ISFSI is shown in Figure 5.3-3.

\subsubsection{Reference Documents}

Pacific Sierra Nuclear, "Topical Report on the Ventilated Storage Cask System for Irradiated Fuel," Rev. 2, Volumes 1 and 2, July 1990. (Docket 72-1007)

U.S. Nuclear Regulatory Commission, Office of Nuclear Material Safety and Safeguards, "Safety Evaluation Report for Pacific Sierra Nuclear Topical Report on the Ventilated Storage Cask System for Irradiated Fuel, Revision 2," March 1991. (Docket 72-1007) 


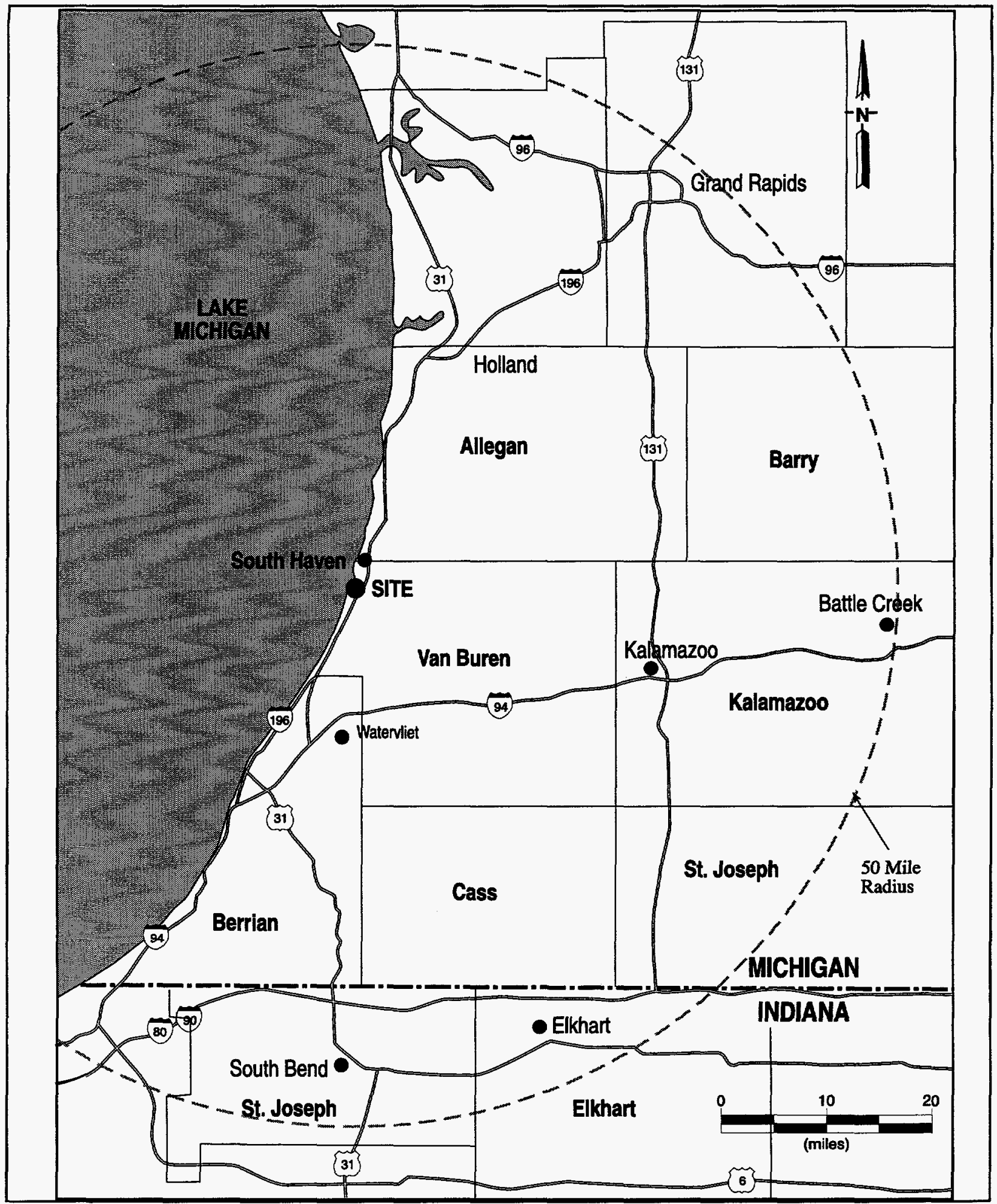

Figure 5.3-1 Palisades Nuclear Power Plant Area Map 


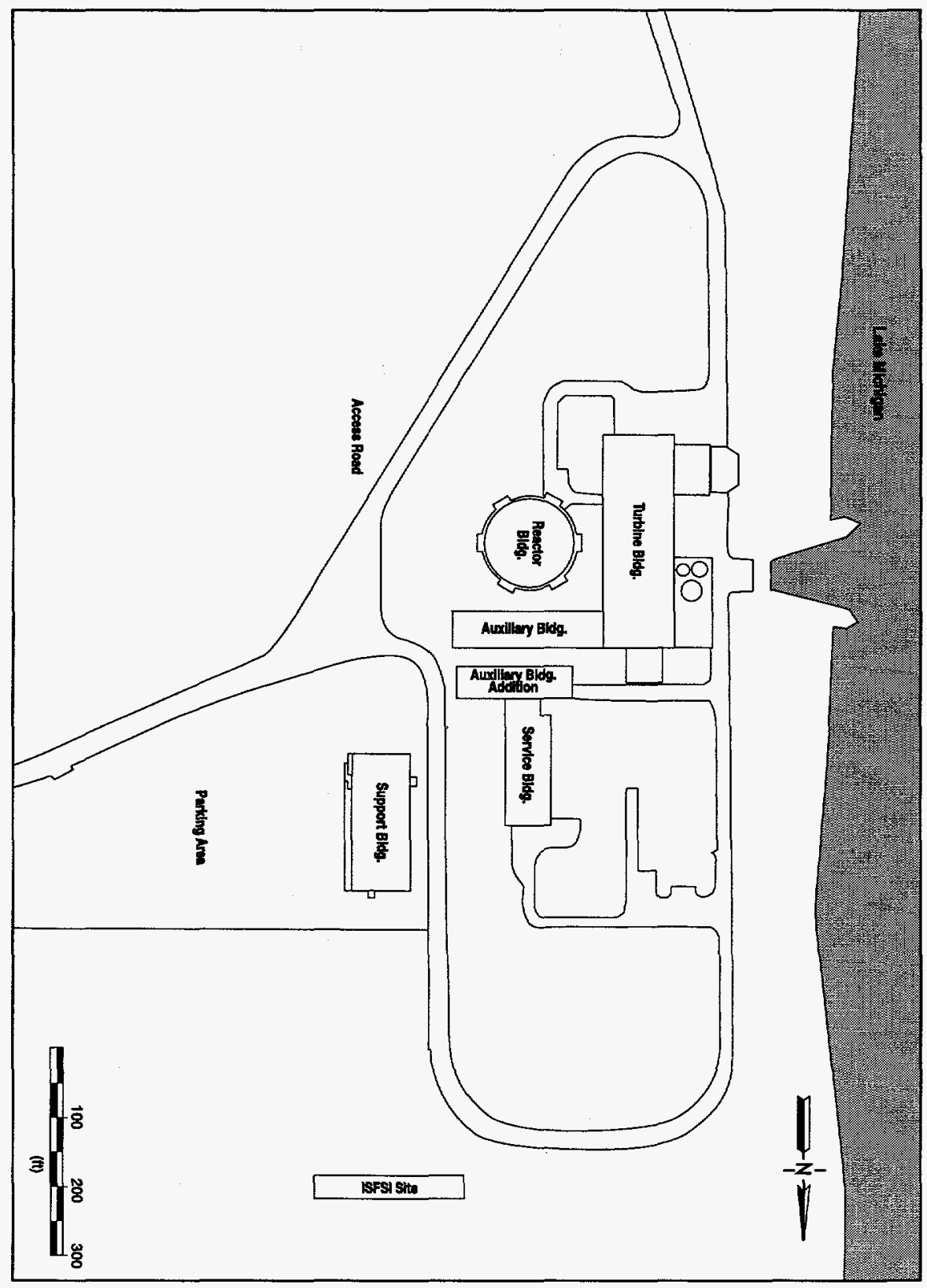

Figure 5.3-2 Palisades Nuclear Power Plant Site Map 


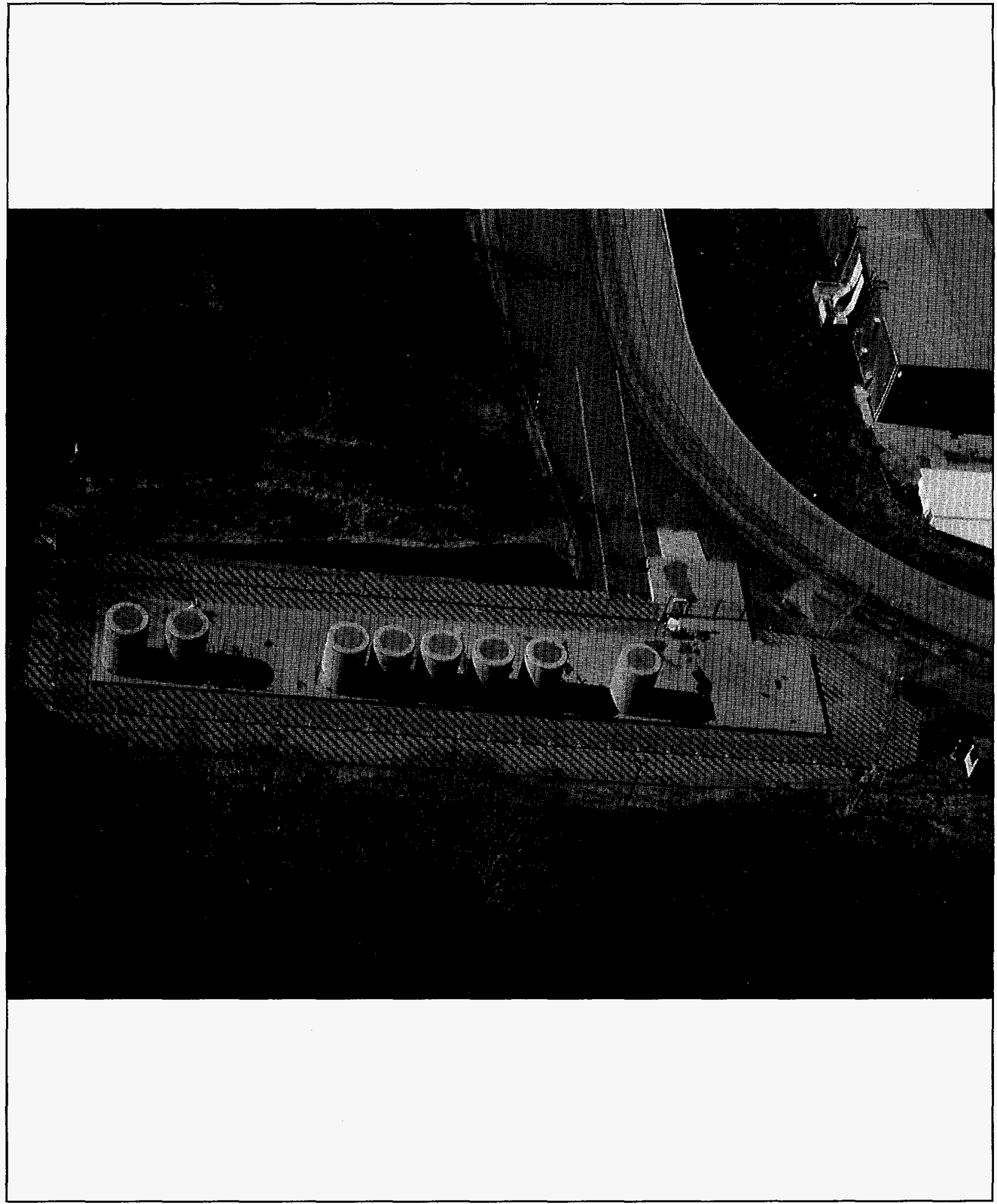

Figure 5.3-3 Photograph of the Palisades ISFSI 


\subsection{Point Beach ISFSI (Docket 72-5)}

\begin{tabular}{cccc}
\hline License No. & DCSS & COC Issue Date & COC Expiration Date \\
\hline General & vSC-24 & $11 / 4 / 91$ & $11 / 30 / 11$ \\
\hline
\end{tabular}

The Point Beach ISFSI employs the VSC-24, designed by Sierra Nuclear Corporation (see Section 3.14). The Point Beach ISFSI is designed to have 48 casks. It currently has two loaded casks.

\subsubsection{History}

The Point Beach Nuclear Power Plant, owned and operated by the Wisconsin Electric Power Company (WEPCO), loaded its first cask in December 1995. In May 1996, an incident occurred during the loading of a VSC-24 cask. During welding of the closure lid, an ignition of hydrogen inside the fully loaded cask displaced the closure lid. There were no injuries, no radiological release, and no damage to the spent fuel or the cask. It was determined that the hydrogen had been formed by a chemical reaction between the Carbo zinc 11 protective coating on the fuel basket and the acidic borated water that was in the cask during closure. Point Beach currently has committed to refrain from loading anymore casks until Bulletin 96-04 has been resolved. NRC Bulletin 96-04, published as a result of the incident, asks all reactor licensees, ISFSI licensees, and DCSS vendors to examine possible chemical or galvanic reactions from materials used in their casks.

\subsubsection{General Description of the Installation}

The Point Beach Nuclear Power Plant is located in Two Creeks, Wisconsin. The ISFSI is within the site boundary of the plant.

\subsubsection{Reference Documents}

Pacific Sierra Nuclear, "Topical Report on the Ventilated Storage Cask System for Irradiated Fuel," Rev. 2," Volumes 1 and 2, July 1990. (Docket 72-1007)

U.S. Nuclear Regulatory Commission, Office of Nuclear Material Safety and Safeguards, "Safety Evaluation Report for Pacific Sierra Nuclear Topical Report on the Ventilated Storage Cask System for Irradiated Fuel, Revision 2," March, 1991. (Docket 72-1007)

U.S. Nuclear Regulatory Commission, NRC Bulletin 96-04: "Chemical, Galvanic, or Other Reactions in Spent Fuel Storage and Transportation Casks," July 5, 1996. 


\section{CURRENT LICENSE APPLICATIONS}

ISFSI and DCSS applications currently under review by the NRC as of September 1996 are listed in Tables 6.1 and 6.2. Pre-applications, amendments, and other submittals that are also under review are not included.

Table 6.1 Site-Specific ISFSI Applications

\begin{tabular}{|l|l|}
\hline ISFSI & Operator \\
\hline Groodhue County & Northern States Powers Company \\
\hline North Anna & Virginia Electric \& Power Company \\
\hline Rancho Seco & Sacramento Municipal Utility District \\
\hline Trojan & Portland General Flectric Company \\
\hline
\end{tabular}

Table 6.2 DCSS Applications

\begin{tabular}{|l|l|}
\hline DCSS & Vendor \\
\hline HI-STAR 100 & Holtec International \\
\hline NUHOMS MP-187 & VECTRA Technologies, Inc. \\
\hline TN-32 & Transnuclear, Inc. \\
\hline TranStor & Sierra Nuclear Corporation \\
\hline
\end{tabular}


7 MONITORED RETRIEVABLE STORAGE, MULTI-PURPOSE CANISTERS AND PRIVATE AWAY-FROM-REACTOR INITIATIVES

(This section reserved for later use) 


\section{APPENDIX A}

\section{GLOSSARY}

\section{Canister}

A canister is a thin metal cylinder that is used to perform the functions of confinement only in a DCSS using a canister/overpack design. A typical canister would be an alloy steel about $2 \mathrm{in}$. thick. It has an internal basket that may be constructed to hold various numbers of fuel assemblies. It is protected from normal, off-normal, and accident conditions by the overpack. The canister is loaded and transferred in a device resembling a transportation cask, and is emplaced into the concrete or steel overpack.

\section{Cask}

A cask is a stand-alone device that performs the functions of confinement, radiological shielding, and physical protection of spent fuel during normal, off-normal, and accident conditions in a DCSS using the cask design. A cask has an internal basket that may be constructed to hold various numbers of fuel assemblies. Typically, a cask is an upright cylinder constructed of an alloy steel that is six or more inches thick with additional gamma and neutron shielding materials. It stands approximately $4.6 \mathrm{~m}$ $(15 \mathrm{ft})$ high and be at least $1.6 \mathrm{~m}(6 \mathrm{ft})$ in diameter.

\section{Certificate of Compliance}

A certificate of compliance is the document issued by the NRC that indicates the acceptability of a DCSS for use at a ISFSI with a general license. It contains the conditions and limitations for operating the storage system. A certificate is issued for the storage of fuel for 20 years.

\section{Confinement}

Confinement is the ability of a DCSS to prevent the release of radioactive substances into the environment.

\section{Containment}

Containment is the ability of a component within the DCSS to contain the spent fuel in an acceptable geometry.

\section{Dry Cask Storage System (DCSS)}

A dry cask storage system is any system that uses a cask or canister as a component in which to store spent nuclear fuel without using water to remove decay heat. A dry cask storage system provides 
confinement, radiological shielding, physical protection, and inherently passive cooling of its spent nuclear fuel during normal, off-normal, and accident conditions.

\section{General License}

A general license is a materials license that has been given to all 10 CFR Part 50 power licensees to store spent fuel outside the reactor storage basin in an ISFSI. The general license requires the use of a DCSS that has received a certificate of compliance from the NRC. The general license conditions are in 10 CFR Part 72, Subparts K and L. The intent of the general license is to streamline the licensing process for power reactors which have already performed the extensive safety assessments and environmental reviews required by a site-specific license. The general license cannot be used to store damage spent fuel.

\section{Independent Spent Fuel Storage Installation (ISFSI)}

An independent spent fuel storage installation is a complex designed and constructed for the interim storage of spent nuclear fuel and other radioactive materials associated with spent fuel storage. It must meet the requirements in 10 CFR Part 72.

\section{Overpack}

jAn overpack is a device into which a canister is placed. An overpack serves a function different from a canister. In storage, the overpack provides the confinement boundary of radiological shielding and protects the canister from impact in the event of an accident. In transportation, it has similar functions but with a different design basis.

\section{Safety Analysis Report (SAR)}

A safety analysis report is the document that is supplied by a DCSS vendor or site-specific ISFSI applicant to the NRC for analysis and confirmatory calculations. The safety analysis report must contain information required in 10 CFR 72.24. The safety analysis report provides references and drawings of the DCSS and/or ISFSI, details of construction, materials, and standards to which the device has been designed.

\section{Safety Evaluation Report (SER)}

A safety evaluation report is the document that the NRC publishes at the completion of a SAR review. It contains all of the findings and conclusions from the evaluation of the submitted SAR.

\section{Site--Specific License}


A site-specific license is a materials license that authorizes the storage of spent fuel outside the reactor storage basin at a ISFSI. The site-specific license must meet the requirements in $10 \mathrm{CFR}$ Part 72, Subparts A-I. It must meet several requirements similar to a 10 CFR Part 50 power reactor license, in which a safety review and an environmental review must be performed. The site-specific license is different from a general license in which: it may be obtained by a non-reactor licensee; it may be issued to decommissioned power plants; it may be used to store damaged spent fuel. A site-specific license is issued for the storage of spent fuel for 20 years.

\section{Spent Fuel}

Spent nuclear fuel or spent fuel refers to fuel that has been withdrawn from a nuclear reactor following irradiation, has undergone at least one year's decay since being used as a source of energy in a power reactor, and has not been chemically separated into its constituent elements by reprocessing. 


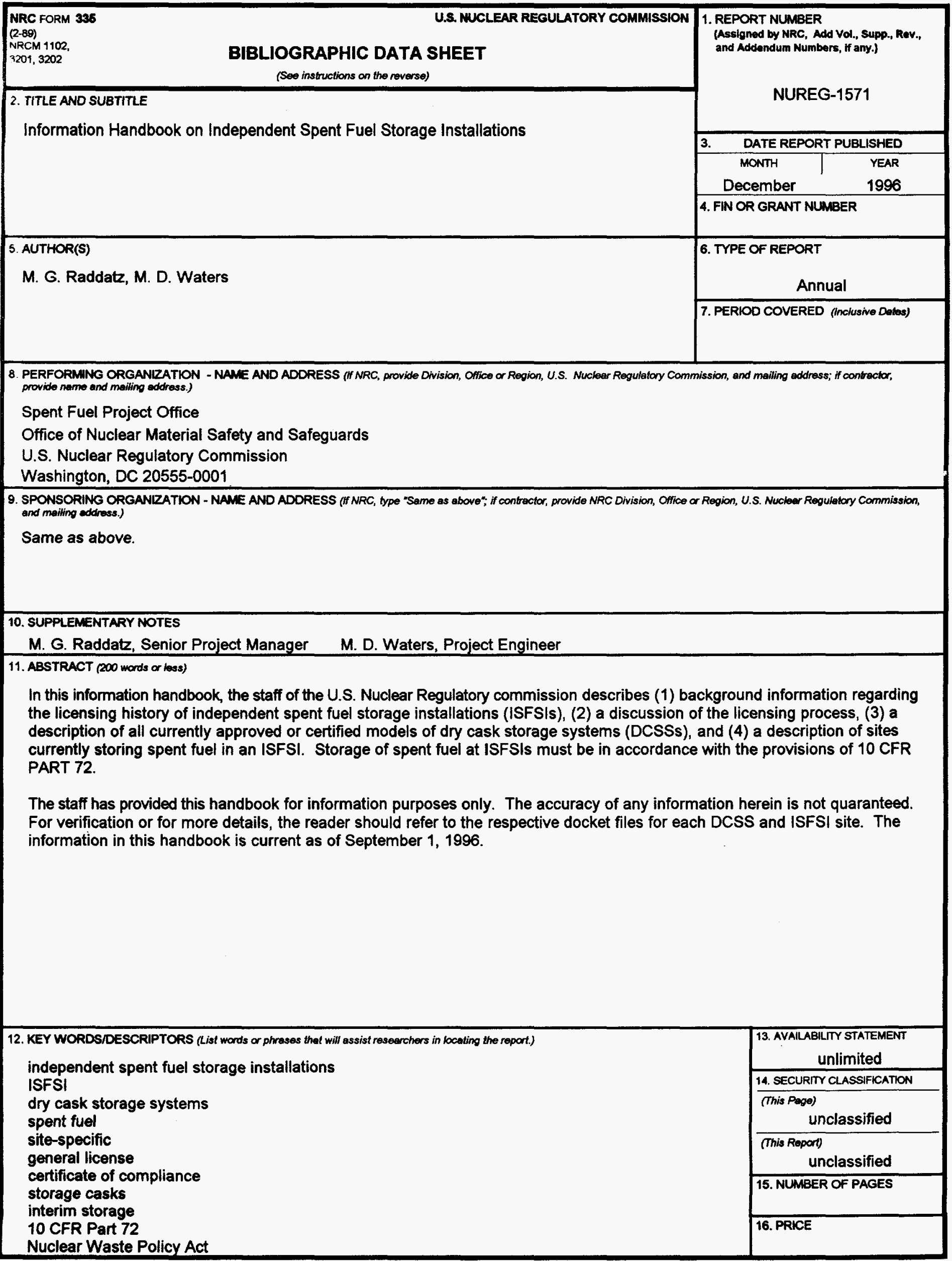

